
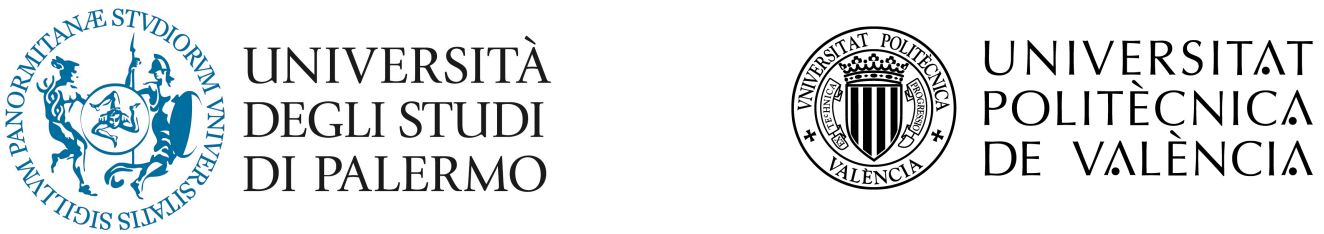

Dottorato in Frutticoltura Mediterranea Dipartimento di Scienze Agrarie e Forestali AGR/03 - Arboricoltura generale e Coltivazioni arboree Departamento de Producción Vegetal

\title{
NUTRITIONAL AND HORMONAL FACTORS AFFECTING FRUIT SET IN AVOCADO (Persea americana Mill.)
}

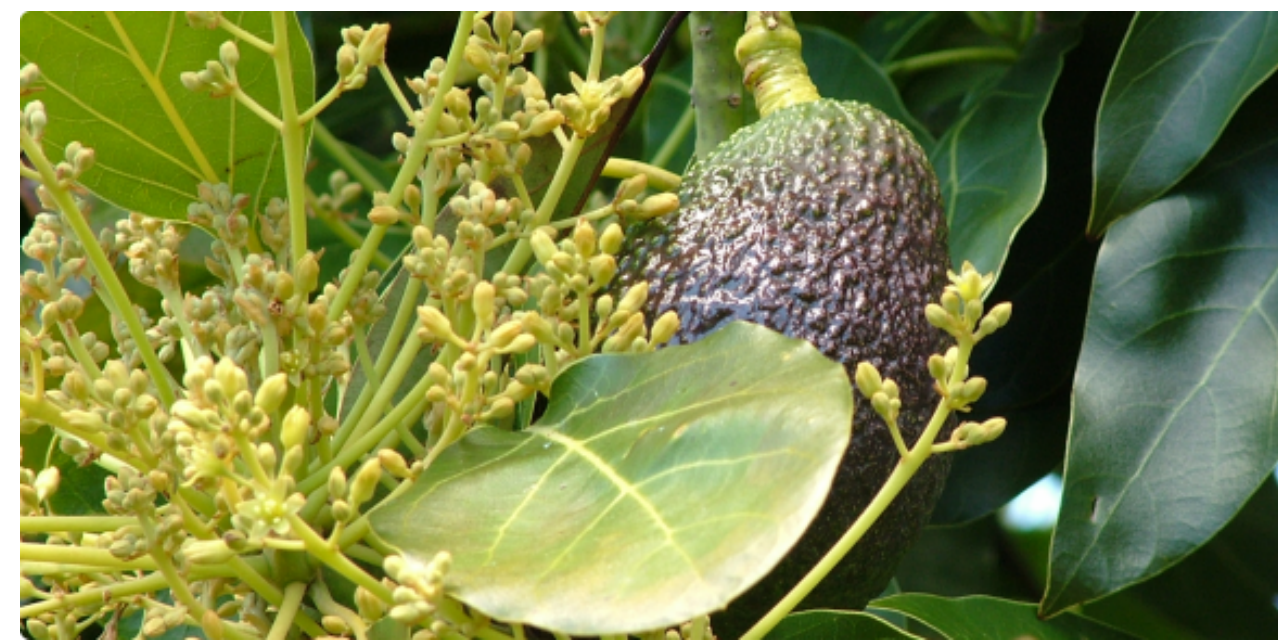

Ph.D STUDENT ANTONIO D'ASARO

SUPERVISOR

PROF.

MANUEL AGUSTÍ FONFRÍA

\author{
COORDINATOR \\ PROF. \\ MARIA ANTONIETTA GERMANÀ
}

CO-SUPERVISOR

PROF.

VITTORIO FARINA

CYCLE XXIX

2016/2017

February 2017 



\section{Index}

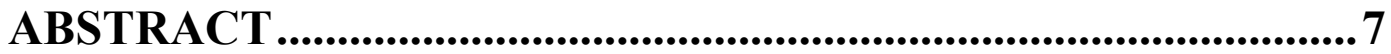

RIASSUNTO

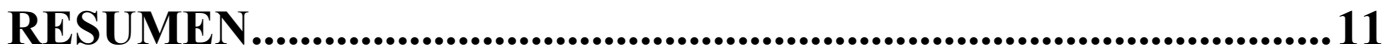

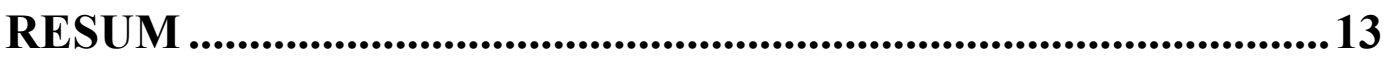

I. GENERAL INTRODUCTION ...................................................17

1. ORIGIN AND GEOGRAPHICAL DISTRIBUTION .......................................... 17

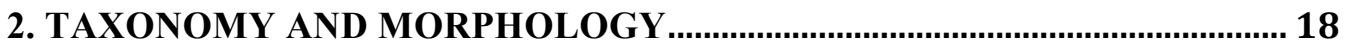

2.1 Taxonomy..........................................................................................................18

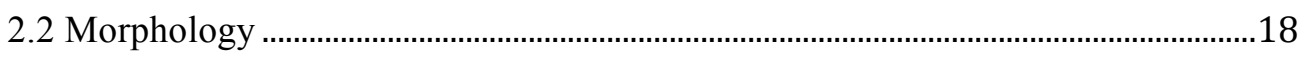

3. VEGETATIVE DEVELOPMENT OF AVOCADO......................................... 22

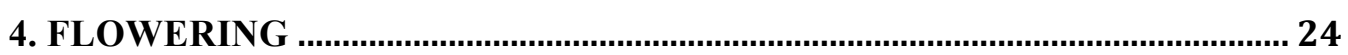

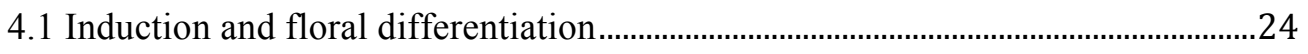

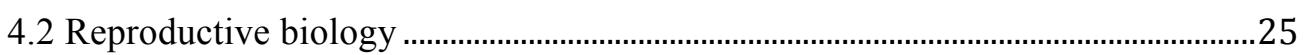

5. FRUIT SET AND DEVELOPMENT OF FRUIT …........................................... 28

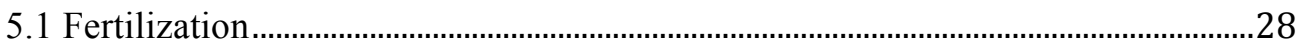

5.2 The physiological fruit drop.....................................................................................29

5.3 Vegetative development-fruit development relationship .......................................30

5.4 Alternate bearing .......................................................................................................

5.5 Stimulation techniques of fruit set ..............................................................................33

6. THE ROLE OF CARBOHYDRATES IN SETTING AND FRUIT

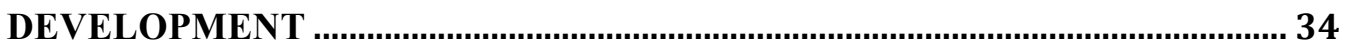

7. HORMONAL CONTROL OF FRUIT SET AND FRUIT DEVELOPMENT 35

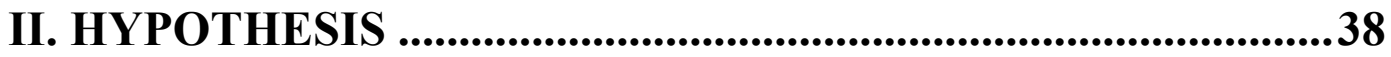

III. MATERIALS AND METHODS............................................40

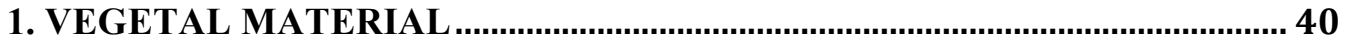

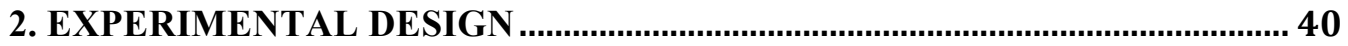

2.1 Intensity of flowering vs. fruit set.......................................................................... 40

2.2. The exogenous control of the abscission of reproductive organ.............................41 
2.3. Vegetative development vs. Reproductive development. Hormonal and nutritional control.

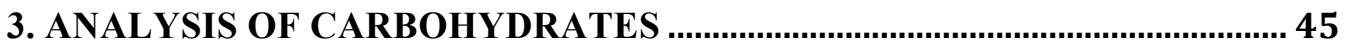

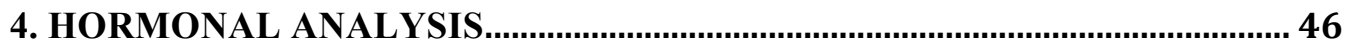

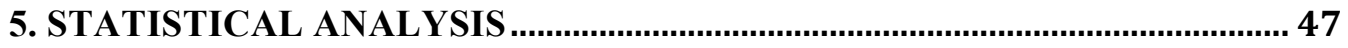

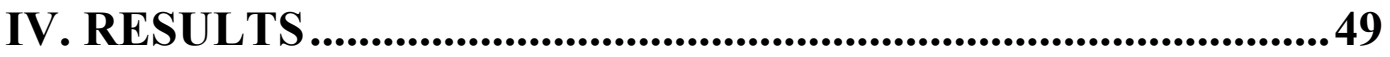

1. INTENSITY OF FLOWERING-FRUIT SET.................................................. 49

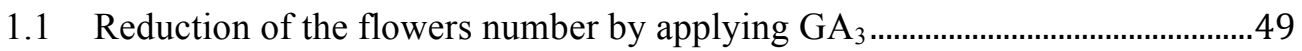

\section{VEGETATIVE DEVELOPMENT- REPRODUCTIVE DEVELOPMENT} RELATIONSHIP. HORMONAL AND NUTRITIONAL CONTROL ................ 52

2.1 The time course of flower abscission....................................................................52

2.2 The time course of fruit abscission. Number of fruits per panicle. Influence of

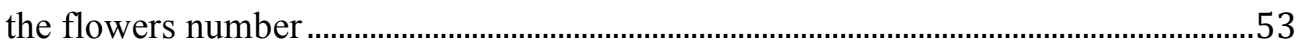

2.3 Carbohydrate consumption..................................................................................56

2.3.1 Consumption during flowering …………………………………………………....

2.3.2 Consumption during the initial development of fruit................................................62

2.4 Endogenous hormonal control.............................................................................67

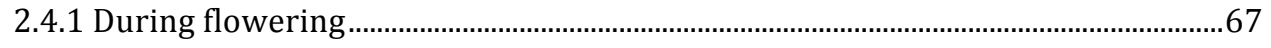

2.4.2 During the initial development of fruit ......................................................................

3. EXSOGENUS CONTROL OF THE ABSCISSION OF REPRODUCTIVES ORGANS.

3.1 Influence of $\mathrm{GA}_{3}$ and $\mathrm{PBZ}$ on the abscission of flowers and fruits. Action of ringing

3.2 Influence of $\mathrm{GA}_{3}$ and $\mathrm{PBZ}$ on individual panicles.................................................85

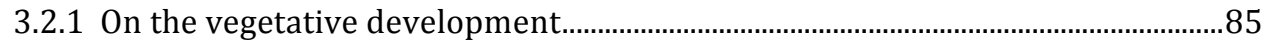

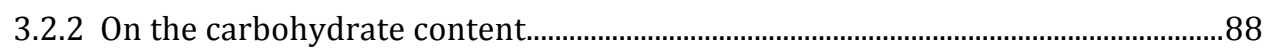

3.3 Influence of Ringing, GA and PBZ on carbohydrate metabolism .....................89

3.3.1 Treatment on individual inflorescences ...................................................................

3.3.1.1 During flowering ..................................................................................................8

3.3.1.2 During the initial development of fruit ………………………………………....93

3.3.2 Treatments to the entire tree ……………………………………………………......98

3.4 Influence of $\mathrm{GA}_{3}$ and PBZ during anthesis and fruit set in the hormonal balance 109 
VI. CONCLUSIONS ................................................................... 118

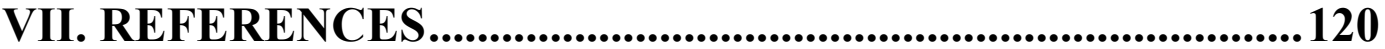


ABSTRACTS 


\section{ABSTRACT}

Under favourable conditions, the avocado sets more fruits than the tree is able to bring to maturity, so that the plant adjusts, during the early stages of development, its ability to nourish them by modifying their number, that is, causing the fruit drop of those who can not maintain their growth rate. Accordingly, carbohydrate availability could be a key factor in the physiological abscission of these fruits. Since this species presents dichogamy, the abscission of fruits has also been attributed to the absence of pollination, but at the same time it has been related to failures in seed development, embryo abortion, seed coat collapse, and with the effect of an environmental stress, especially by cold or heat.

In order to demonstrate if in avocado the competition between flowers is responsible for fruit set and initial development of the fruit, it has been determined the influence of the flowering intensity in the time course of carbohydrate and hormonal content, in the rate of fruits abscission and its evolution, and finally, on percentage of fruits set.

For this purpose experiments have been designed in order to: 1) reduce flowering, and with it the competition between flowers, 2) reduce vegetative growth, and 3) promote fruit set.

The experiments were carried out in commercial orchards of avocado (Persea americana Mill.) cv. Hass (group A flowering), located in Torrent and Llaurí (Valencia), Spain, and in Caronia Marina (Messina), Italy. Adult trees (5-8 years), planted at a distance of $5 \times 6 \mathrm{~m}$. In all of them there were cv. Fuerte (flowering group B) to ensure pollination.

The results showed that gibberellic acid applied during the floral bud inductive period delayed sprouting, reduced the number of flowers per panicle, increased apical shoot length, and delayed fruitlet abscission.

Gibberellic acid applied at anthesis enhanced fruit set and delayed fruitlet abscission. It correlated with an immediate and temporary increase of GA, IAA and $t \mathrm{Z}$ content. But the $\mathrm{GA}_{1}$ immeditely derived in its catabolite $\mathrm{GA}_{8}$. Since IAA synthesis precedes fruit set and $t Z$ increasing content, the possibility that fertilization triggers the $t Z$ synthesis mediated by auxin cannot be discarded.

Gibberellic acid applied at the beginning of fruit set also, temporarily, increased 
the endogenous concentration of $\mathrm{GA}_{1}$ and $\mathrm{GA}_{8}$, As well as the number of fruits that initiated the development and delayed their abscission.

Paclobutrazol applied at anthesis reduced the growth of the terminal shoot $y$ anticipated flowers abscission, but did not affect initial fruit set.

In no case it was possible to increase the total number of fruits per panicle, so that the competition between developing organs is not the cause of the lack of fruit set in this species. 


\section{RIASSUNTO}

In condizioni favorevoli, l'avocado riesce ad allegare più frutti di quelli che l'albero è capace di portare a maturazione, in queste condizioni la pianta modifica, durante le prime fasi di sviluppo, la sua capacità di nutrirli modificando il numero, provocando la cascola di quelli che non posso mantenere il ritmo di crescita. Di conseguenza, la disponibilità di carboidrati potrebbe essere un fattore chiave per quanto riguarda la cascola dei frutti. Dato che questa specie presenta la dicogamia, l'abscissione dei frutti si è attribuita anche all'assenza di impollinazione, però allo stesso tempo si è relazionata a problemi riguardo lo sviluppo del seme, aborto dell'embrione, collasso della coperta seminale, e per effetto dello stress ambientale, specialmente per calore e freddo.

Con il fine di dimostrare se nell'avocado la competizione tra fiori è responsabile dell'allegagione e dello sviluppo iniziale dei frutti, abbiamo determinato: l'influenza dell'intensità di fioritura sull'evoluzione del contenuto dei carboidrati e ormoni, nel ritmo di abscissione dei frutti e la sua evoluzione, e in fine, sulla percentuale di frutti allegati. Per fare tutto ciò, abbiamo disegnato diversi esperimenti in modo da: 1) ridurre la fioritura, e con questa la competizione tra fiori, 2) ridurre lo sviluppo vegetativo, e 3) promuovere l'allegagione dei frutti.

Gli esperimenti sono stati effettuati presso frutteti commerciali di avocado (Persea americana Mill.) cv. Hass (gruppo A della fioritura), siti in Torrent e Llaurí (Valencia), Spagna, e in Caronia Marina (Messina), Italia. Sono stati presi in considerazione alberi adulti (5-8 anni di età), piantati a una distanza di 5 × 6 m. In tutti i frutteti erano presenti alberi della cv. Fuerte (gruppo B della fioritura) per assicurare l'impollinazione.

I risultati dimostrano che applicando acido gibberellico durante il periodo di induzione fiorale si ha avuto un ritardo del germogliamento, riduzione del numero di fiori in ciascuna pannocchia, incremento dello sviluppo del germoglio apicale, e ritardo dell'abscissione fisiologica dei frutticini. L'applicazione di acido gibberellico durante l'antesi ha migliorato l'allegagione e ha ritardato l'abscissione dei frutticini. Ciò è correlato a un immediato e temporaneo incremento del contenuto di $\mathrm{GA}_{1}$, IAA e $t \mathrm{Z}$. Ma $\mathrm{GA}_{1}$ derivò immediatamente nel suo catabolite $\mathrm{GA}_{8}$. Dal momento che la sintesi di IAA precede l'allegagione e il 
crescente aumento del contenuto di $t Z$, la possibilità che la fecondazione innescherebbe la sintesi di $t \mathrm{Z}$ mediata dall'auxina non può essere scartata.

L'applicazione di acido gibberellico all'inizio dell'allegagione, anche in questo caso ha aumentato temporaneamente, la concentrazione endogena di $\mathrm{GA}_{1}$ e GA, così come il numero di frutti che iniziano lo sviluppo, e ha ritardato l'abscissione di quest'ultimi.

L'applicazione di paclobutrazol durante l'antesi ha ridotto la crescita del germoglio terminale e ha anticipato l'abscissione dei fiori, ma non ha influenzato l'allegagione iniziale.

In nessun caso si è riusciti ad aumentare il numero totale dei frutti per pannocchia, ciò significa che la competizione tra organi in via di sviluppo non è la causa della mancata allegagione in questa specie. 


\section{RESUMEN}

En condiciones favorables, el aguacate cuaja más frutos de los que el árbol es capaz de llevar a la madurez, de modo que la planta ajusta, durante las primeras fases del desarrollo, su capacidad de nutrirlos modificando su número, esto es, provocando la caída de los que no pueden mantener su tasa de crecimiento. De acuerdo con ello, la disponibilidad de carbohidratos podría ser un factor clave en la abscisión fisiológica de estos frutos. Dado que esta especie presenta dicogamia, la abscisión de frutos también se ha atribuido a la ausencia de polinización, pero al mismo tiempo se ha relacionado con fallos en el desarrollo de la semilla, el aborto del embrión, el colapso de la cubierta seminal, y con el efecto de un estrés ambiental, especialmente por frío o calor.

Con el fin de demostrar si en el aguacate la competencia entre flores es responsable del cuajado y desarrollo inicial del fruto, se ha determinado la influencia que la intensidad de floración tiene en la evolución del contenido en carbohidratos y hormonas, en la tasa de abscisión de frutos y su evolución, y, finalmente, sobre porcentaje de frutos cuajados. Para ello se han diseñado experimentos para 1) reducir la floración, y con ello la competencia entre flores, 2) reducir el desarrollo vegetativo, y 3) promover el cuajado de frutos.

Los experimentos se llevaron a cabo en huertos comerciales de aguacate cv. Hass (grupo A de floración), localizados en Torrent y Llaurí (Valencia), España, y en Caronia Marina, Messina, Italia. Se utilizaron árboles adultos (5-8 años de edad), plantados a una distancia de 5 × 6 m. En todos ellos había árboles del cv. Fuerte (grupo B de floración) para asegurar la polinización.

Los resultados demuestran que la aplicación de ácido giberélico durante la inducción floral retrasó la brotación, redujo el número de flores por panícula, aumentó la longitud del brote desarrollado a partir de la yema terminal de la panícula, y retrasó la abscisión fisiológica de frutos.

Su aplicación en antesis promovió el cuajado de frutos y retrasó su abscisión. Ello se corresponde con un aumento inmediato y temporal de la síntesis endógena de $\mathrm{GA}_{1}$, IAA y $t \mathrm{Z}$. Pero la $\mathrm{GA}_{1}$ derivó inmediatamente en su catabolito GA 8 . Puesto que la síntesis de IAA precedió al cuajado y al contenido creciente de $t \mathrm{Z}$, la 
posibilidad de que la fecundación desencadene la síntesis de $t \mathrm{Z}$ mediada por la auxina no puede ser descartada.

La aplicación de ácido giberélico al inicio del cuajado también aumentó, temporalmente, la concentración endógena de $\mathrm{GA}_{1}$ y $\mathrm{GA}_{8}$, así como el número de frutos que iniciaron el desarrollo, y retrasó su abscisión.

La aplicación de paclobutrazol en antesis redujo el crecimiento del brote terminal y anticipó la abscisión de las flores, pero no afectó el cuajado inicial.

En ningún caso se consiguió aumentar el número total de frutos por panícula, de modo que la competencia entre órganos en desarrollo no es la causa de la falta de cuajado en esta especie. 


\section{RESUM}

En condicions favorables, l'alvocat qualla més fruits dels que l'arbre és capaç de portar a la maduresa, de manera que la planta s'ajusta, durant les primeres fases del desenvolupament, la capacitat de nodrir-modificant el nombre, és a dir, provocant la caiguda dels que no poden mantenir la seva taxa de creixement. D'acord amb això, la disponibilitat de carbohidrats podria ser un factor clau en la abscisió fisiològica d'aquests fruits. Atès que aquesta espècie presenta dicogàmia, la abscisió de fruits també s'ha atribuït a l'absència de pol·linització, però al mateix temps s'ha relacionat amb errors en el desenvolupament de la llavor, l'avortament de l'embrió, el col·lapse de la coberta seminal, i amb l'efecte d'un estrès ambiental, especialment per fred o calor.

Per tal de demostrar si en l'alvocat la competència entre flors és responsable del quallat i desenvolupament inicial del fruit, s'ha determinat la influència que la intensitat de floració té en l'evolució del contingut en carbohidrats i hormones, en la taxa d'abscisió de fruits i la seva evolució, i, finalment, sobre percentatge de fruits quallats. Per això s'han dissenyat experiments per a 1) reduir la floració, i amb això la competència entre flors, 2) reduir el desenvolupament vegetatiu, i 3) promoure el quallat de fruits.

Els experiments es van dur a terme en horts comercials d'alvocat cv. Hass (grup A de floració), localitzats a Torrent i Llaurí (València), Espanya, i en Caronia Marina, Messina, Itàlia. Es van utilitzar arbres adults (5-8 anys d'edat), plantats a una distància de $5 \times 6 \mathrm{~m}$. En tots ells hi havia arbres del cv. Fort (grup B de floració) per assegurar la pol·linització.

Els resultats demostren que l'aplicació d'àcid giberèlic durant la inducció floral retardar la brotada, va reduir el nombre de flors per panícula, va augmentar la longitud del brot desenvolupat a partir del rovell terminal de la panícula, i va retardar la abscissió fisiològica de fruits.

La seva aplicació en antesi va promoure el quallat de fruits i va retardar la seva abscisió. Això es correspon amb un augment immediat i temporal de la síntesi endògena de $\mathrm{GA}_{1}$, IAA i $t Z$. Però la $\mathrm{GA}_{1}$ va derivar immediatament en el seu catabolit $\mathrm{GA}_{8}$. Ja que la síntesi de IAA va precedir al quallat $\mathrm{i}$ al contingut 
creixent de $t \mathrm{Z}$, la possibilitat que la fecundació desencadeni la síntesi de $t \mathrm{Z}$ intervinguda per l'auxina no pot ser descartada.

L'aplicació d'àcid giberèlic a l'inici del quallat també va augmentar, temporalment, la concentració endògena de $\mathrm{GA}_{1}$ i GA 8 , així com el nombre de fruits que van iniciar el desenvolupament, i va retardar la seva abscisió.

L'aplicació de paclobutrazol en antesi va reduir el creixement del brot terminal i va anticipar la abscisió de les flors, però no va afectar el quallat inicial.

En cap cas es va aconseguir augmentar el nombre total de fruits per panícula, de manera que la competència entre òrgans en desenvolupament no és la causa de la manca de quallat en aquesta espècie. 



\section{GENERAL INTRODUCTION}




\section{GENERAL INTRODUCTION}

\section{ORIGIN AND GEOGRAPHICAL DISTRIBUTION}

The avocado scattering center is in Central America and southern Mexico. The origin in Mesoamerica includes habitats from sea level to over 3,000 meters above sea level, covering a wide range of climates and soil types, which explains its great genetic diversity and adaptability. Its introduction in South Africa, Israel, Chile, Australia and the United States, has resulted in significant genetic improvements in its quality and agronomic factors, as well as the point of view of the consumer (Cerdas et al., 2006).

The avocado belongs to the Lauraceae family, one of the most primitive families of dicots, consisting of 52 genera and about 3,500 species. The genus Persea consists of 150 species distributed throughout tropical and subtropical regions, especially Asia and America, where there are about 80 species (Bernal y Díaz, 2005).

Within genus Persea three species are recognized of agronomic interest, one of which, the P. americana, is composed of several taxa, which are popularly described as races. Although you can distinguish numerous varieties within each species, at present there are only three that are marketed and are considered geographical ecotypes:

- P. americana Mill., var. Americana. It corresponds to the Antillean race or lowland, originates from tropical areas, and grows below 1200 musl in the tropics.

- P. americana (Schlet + Cham) Blake, var. Drymifolia. Known as Mexican race, it is distributed in the eastern slopes of the highlands, at altitudes above 1000 musl and in hot climates, from arid to semiarid.

- P. americana Williams, var. Guatemalensis. Known as Guatemalan race, it grows from humid and hot climate of the rainy tropical forest to semiarid places, between 100 and 2300 musl.

The avocado has increased in importance in recent years in many countries around the world. The United States, Mexico and Brazil are the largest producers, while 
Israel, South Africa, Australia, New Zealand, Philippines, Spain, Cyprus, Canary Islands, Chile, Ecuador, Venezuela, Greece, and the Caribbean are actively increasing commercial production (B.O Bergh, personal communication; Gustafson 1976). Spain is the only European country with a significant commercial production of avocados, the most cultivated part is the Andalusian Mediterranean coast, mainly the provinces of Malaga and Granada.

\section{TAXONOMY AND MORPHOLOGY}

\subsection{Taxonomy}

Velásquez (2006), presents the following description:

Kingdom: Vegetable

Division: Spermatophyta

Subdivision: Angiospermae

Class: Dicotyledoneae

Subclass: Dipetala

Order: Ranales

Family: Lauraceae

Genus: Persea

Species: Persea americana Miller, Persea gratissima Gaerth, Persea drymifolia Blake.

\subsection{Morphology}

The avocado is a perennial plant of great vegetative growth, arriving in its natural habitat to a height of 10 to $12 \mathrm{~m}$. It has shallow roots, which absorb water and nutrients mainly in the apices through the primary tissues; this determines the susceptibility of the tree to excessive moisture that induces to fungi attacks and vascular rots. The branches are abundant, thin, fragile and sensitive to the sunburn and frost, can easily be broken when loading many fruits or by the action of the wind.

Plant: Extremely vigorous tree (powerful trunk with vigorous ramifications), and can reach up to $20 \mathrm{~m}$ of height. 
Leaves: Evergreen tree. Alternating leaves, with peduncles, very bright. When they are young people they have a reddish colour and when arriving at the maturity they become smooth, coriaceous and of an intense green.

Flowers: perfect green-yellow, $1.10 \mathrm{~cm}$ in diameter, calyx of 3 sepals and corolla of 3 petals, 12 stamens, 9 of which are functional and 3 staminodes, single pistil with a single carpel and a single egg, and whose floral formula is 3-3-6-3-3 (Figs. $1-2-3)$.

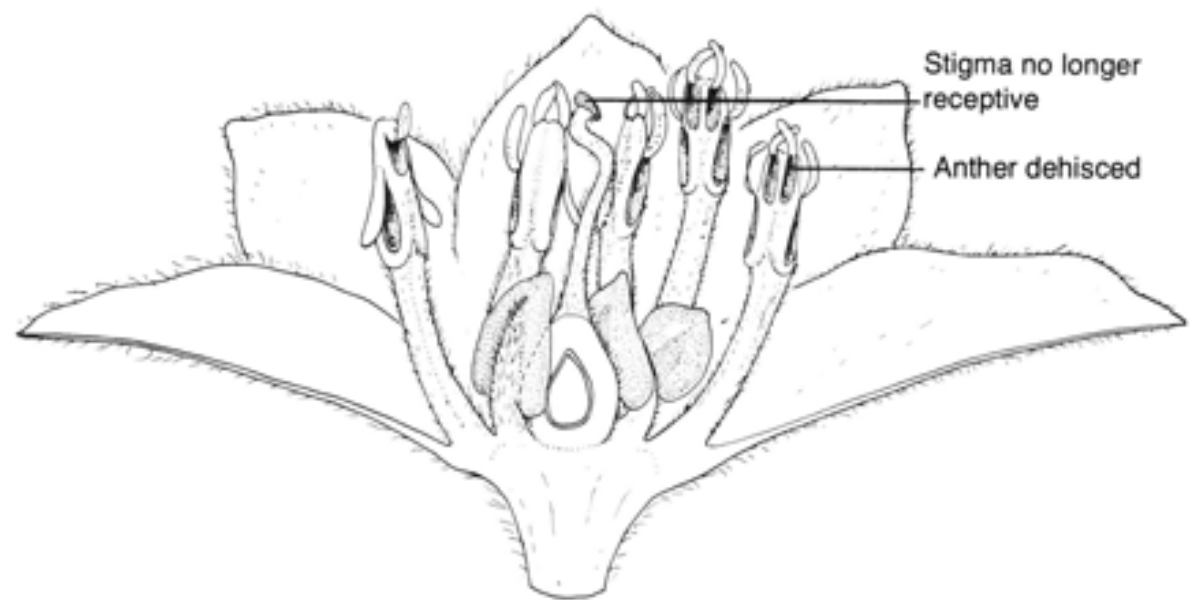

Figure 1: Longitudinal section of avocado male flower.

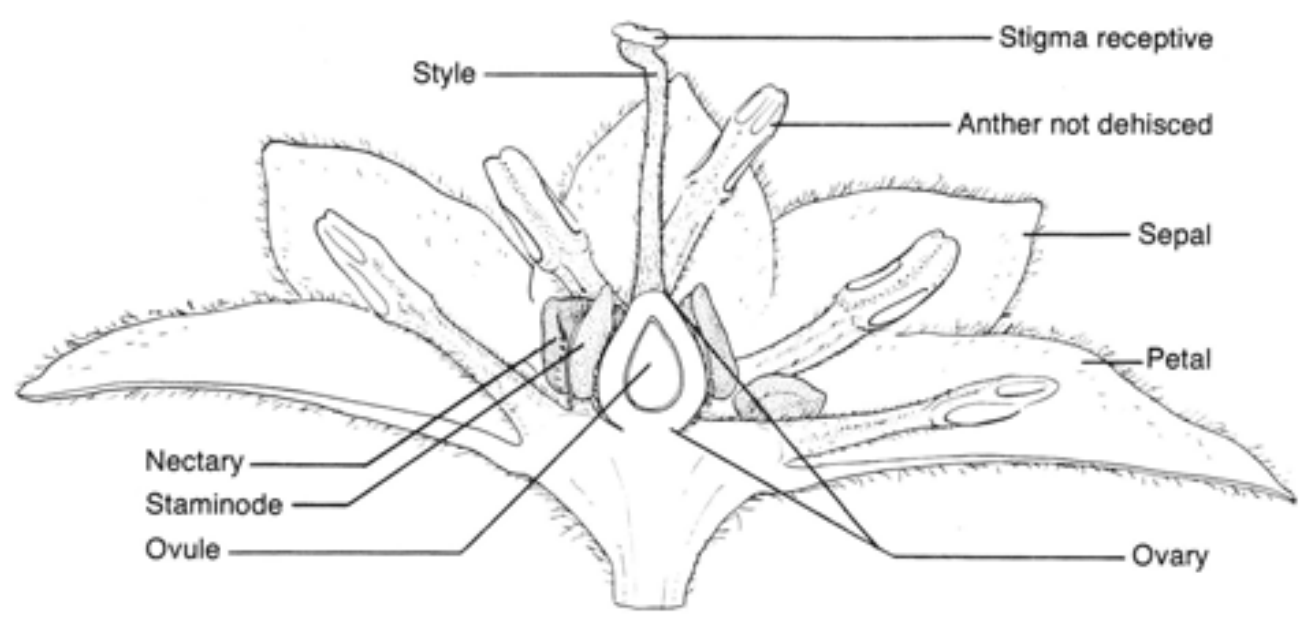

Figure 2: Longitudinal section of avocado female flower. 


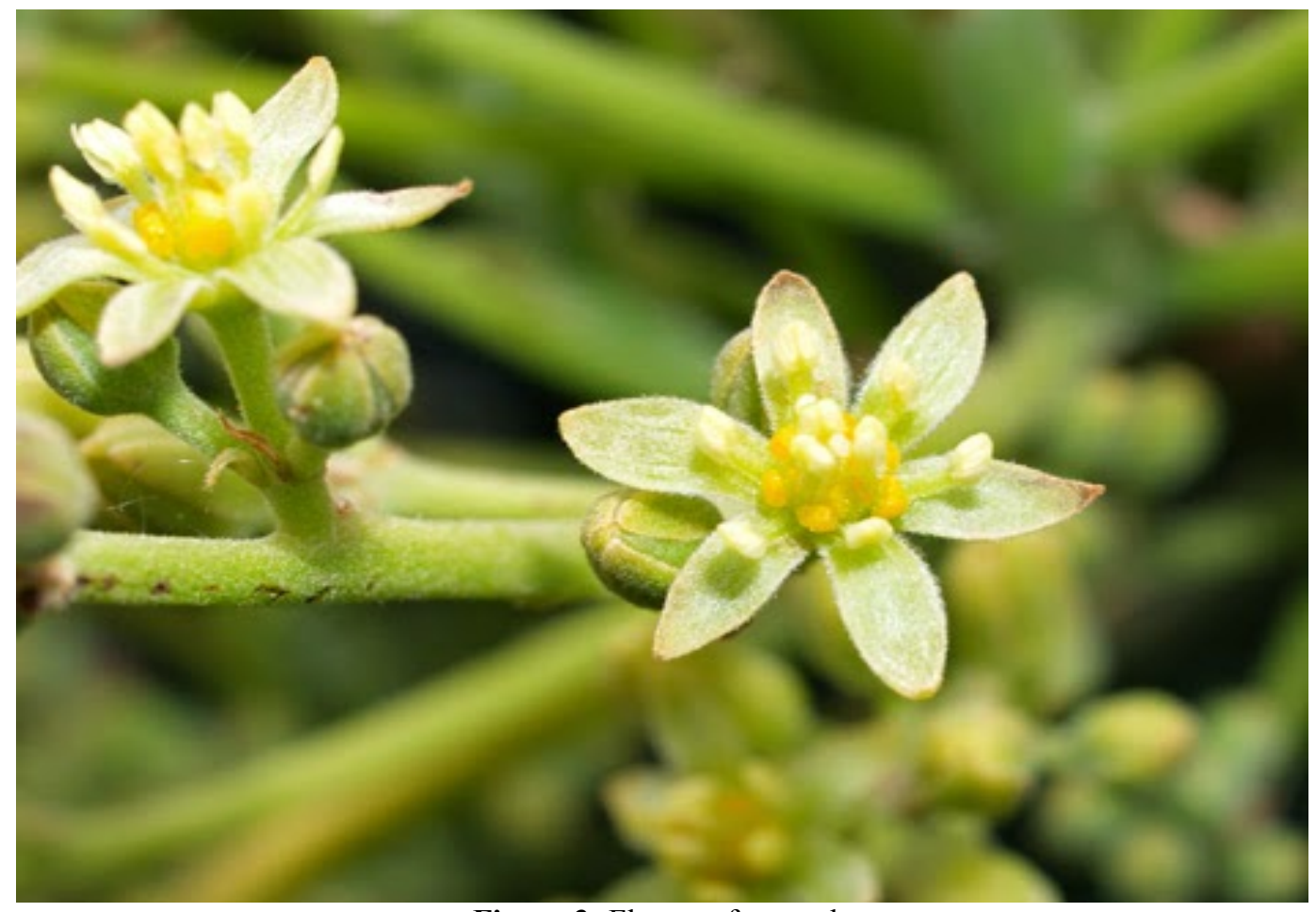

Figure 3: Flower of avocado.

Inflorescences: They have about $30 \mathrm{~cm}$ of length and contain on average around 250 flowers; an adult of avocado tree can exceed one million flowers. The majority of inflorescences arise from the axillary buds placed in more terminal positions of the vegetative shoots, and rarely originate from secondary or not terminal buds; the terminal bud of this shoot is vegetative, giving this way continuity, but can abort and not can pursue the growth. It has been suggested (Scora et al., 2007) that this inflorescence is a tirso with the primary axis paniculate, ending in a vegetative bud, and with secondary axes dicasicos. The flowering, depending on the variety, occurs between February and April (Fig. 4). 


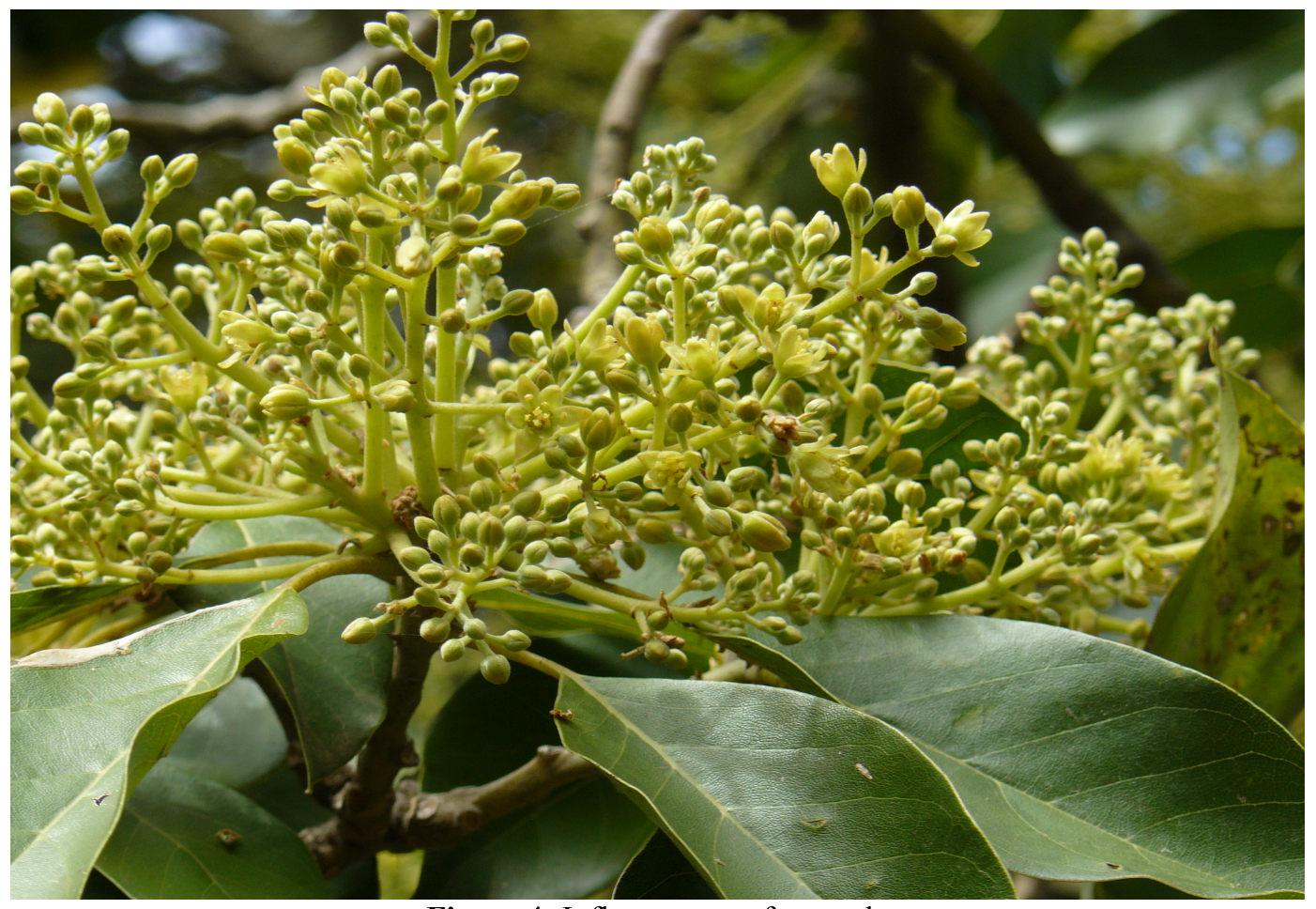

Figure 4: Inflorescence of avocado.

Buds: in avocados there are two types of buds:

- Floral (Fig. 5)

- Vegetative (Fig. 6)

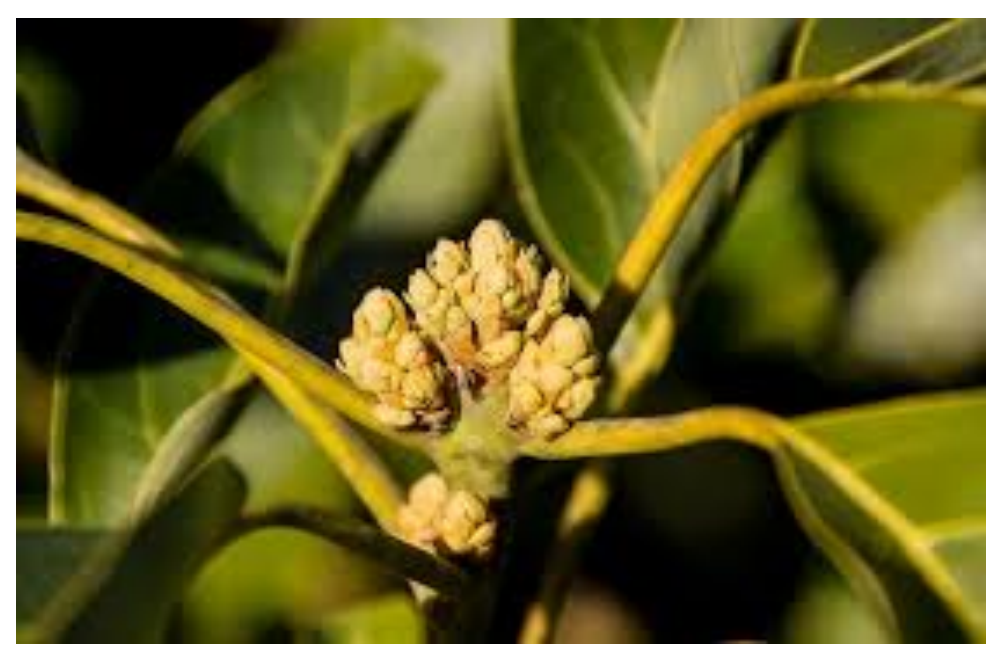

Figure 5: Avocado floral bud. 


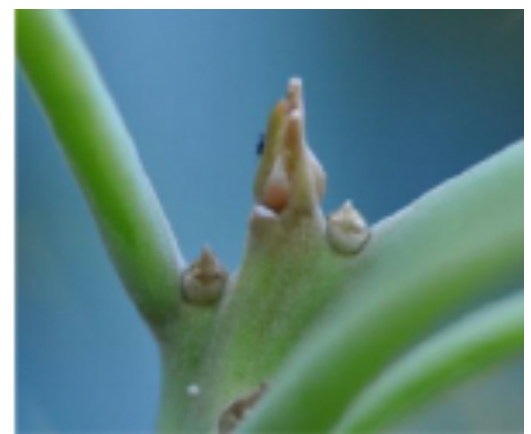

Figure 6: Avocado vegetative bud.

The flower bud is thicker than the vegetative and usually has a more yellowish colour. Up to form the inflorescence it passes through intermediate states, developing a main axis and several branches in which the flowers are located.

Fruit: Berry with a single seed, oval, sometimes spherical. Smooth or rough exocarp, light green to very dark surface, almost black. Greenish-yellow mesocarp, soft and rich in fatty acids. The maturation of the fruit does not take place until it is separated from the tree.

Root system: It is imperfect in terms of water absorption. Despite that it can be extended up to the 120 and $150 \mathrm{~cm}$ depth, the largest amount of absorbent roots are located between 0 and $60 \mathrm{~cm}$. Depending on the type of soil, the roots are more or less absorbed and assumes lateral positions. The primary lateral roots branch off mostly in secondary lateral, which in turn begin to divide, but in more open angles. This system of branching develops abundance of rootlets, of white colour. This superficial radical structure, is extensively suberized and is relatively inefficient in the absorption of water, which can cause the loss of fruits during the critical stages of development such as the fruit set and growth of this (Gardiazabal, 2004).

\section{VEGETATIVE DEVELOPMENT OF AVOCADO}

Avocado plantations start their production in the third year of established and stabilizes it from the seventh or eighth year. The three major events of the phenological cycle of avocado are the root growth, the vegetative growth and the flowering-fruiting (Cristoffanini, 1996). In conditions of tropical climate, the avocado can have along a same year one or more vegetative cycles followed by a period of root growth. The roots begin their growth when the first vegetative growth begins to decline. Subsequently, a second period of vegetative growth 
begins, restoring this way the balance between a phase of root growth followed by another vegetative phase (Calabrese, 1992; Hernandez, 1991) (Fig.7).

As in most of the evergreen fruit trees the growth of the vegetative shoots of the Avocado is synchronized in the flows that vary in force, duration and magnitude (Scora et al., 2002; Rocha-Arroyo et al., 2011). These flows generally occur two or three times a year and may or may not include the entire tree (Davenport, 1986). Their number depends on the environmental conditions, the magnitude of each one of them is variable, and usually only one is responsible for the reproductive development (Salazar-Garcia et al., 2006; Salazar-Garcia et al., 2007; Rocha-Arroyo et al., 2011).

The vegetative growth presents a defined sigmoidal growth pattern, in which the initial stage presents a slow growth, followed by a significant increase and a final stage of stable growth. The stage of accelerated growth coincides with the flowering stage, in which it is possible to achieve a rate of growth of the vegetative shoots of up to $3 \mathrm{~mm} /$ day. These streams can last 3 to 4 months. In the subtropics the magnitude of this growth is determined strongly by the seasonality, being higher in spring (Dixon, 2007).

In a study conducted by Rosales et al. (2003) it was observed that the apical vegetative growth of "Hass" avocado starts 7 days after the start of the sprouting of reproductive buds, rising progressively from the $29^{\text {th }}$ days to submit its highest rate of growth to the $67^{\text {th }}$ days, then drops to $144^{\text {th }}$ days, after which time the rate of vegetative growth is virtually zero. In the case of lateral shoots the growth occurs in a single period which spans from the $29^{\text {th }}$ to the $122 \mathrm{t}^{\mathrm{h}}$ days, being its intensity lower that the apical vegetative growth.

The temperature is the main factor responsible for the changes in the vegetative phase to the reproductive phase. Subtropical avocados cultivars, that are developed with success in the tropics at high altitudes and in the subtropics with cold winters, can produce floral buds only if they are kept under regimes of cold temperatures (Gazit and Degani, 2002), a requirement that is not, however, essential to the cultivars of avocados that grow in cold climates, in semi-arid and tropical and semi-tropical climates. 


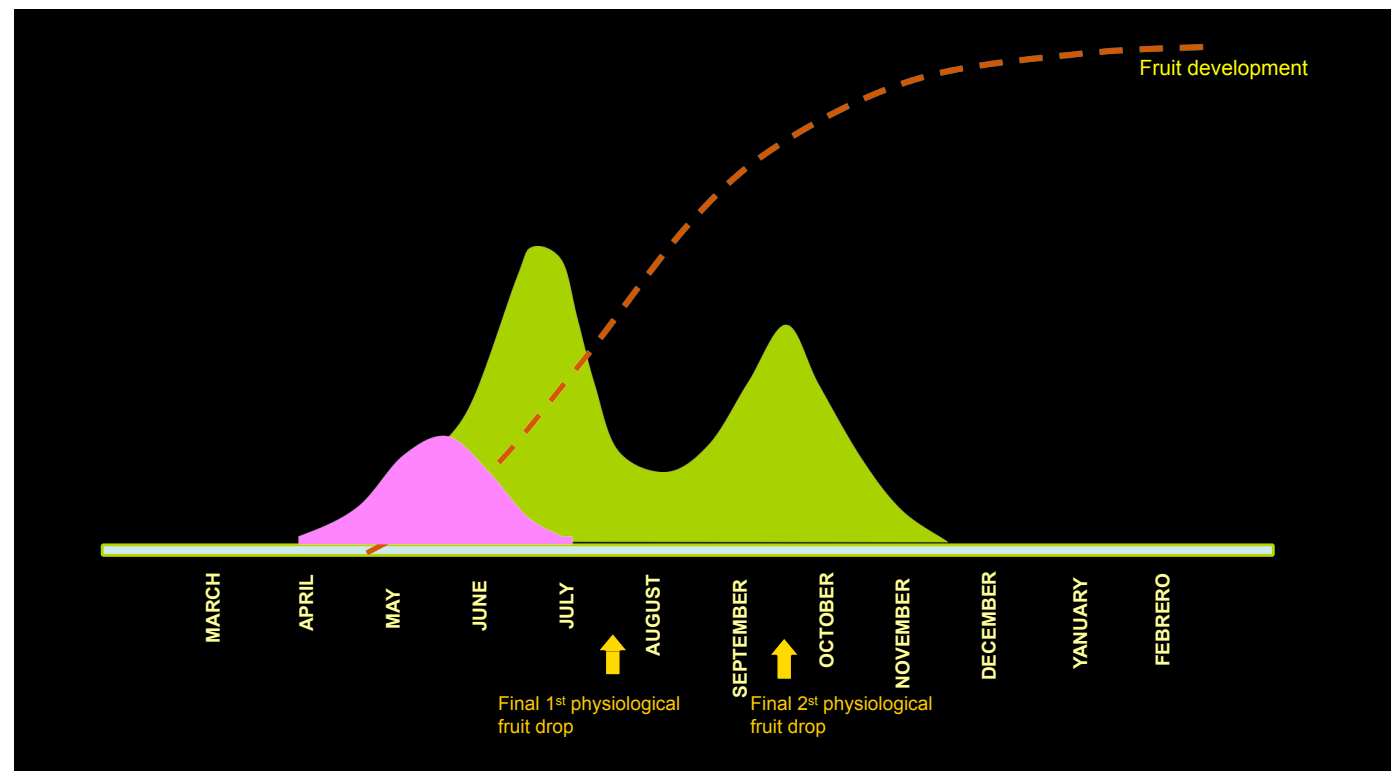

Figure 7: Phenological growth stages of the avocado tree. Pink area (flowering), Green area (vegetative development) and Curve (fruit development).

\section{FLOWERING}

\subsection{Induction and floral differentiation}

Little is yet known about the reproductive biology of this species. It has been pointed out that the first anatomical signs of the floral initiation are detectable in autumn or early winter, depending on the breed of avocado and on the locality (Scholefield et al., 1985; Thorp et al., 1993), and the process of floral initiation occurs only after the shoots enter a period of rest (Davenport, 1982, 1986).

However, recent studies suggest that the process of initiation begins long before (Salazar-Garcia et al., 1998, 1999), so for Southern California, and for the cv. Hass, the transition from the vegetative state to the reproductive in the sprouting of summer takes place at the end of the expansion of sprouting, i.e. from the end of July to August. Similarly, Calabrese (1992) said that the differentiation of the floral buds takes place in November-December.

At the end of the growth of the summer sprouting (end of July to the HN), the axis of the primary meristem form one or two secondary axes, in the armpits of the bracts of the inflorescence, whose meristems can develop further and be transformed into flowers, but in this state of development its transformation is not yet irreversible. It has been suggested that under unfavourable environmental conditions for the reproductive growth, the development of these meristems is 
penalized. About three months later, at the end of November, four secondary floral meristems are already present, and we are able to appreciate macroscopic signs of a partial senescence of the most external bracts of the apical buds. During this state of development, the bud is irreversibly induced to flower. Two months later, at the end of December, the bracts of the buds are separated, and the flowering bud can be easily recognized by its external form. In this state of development of the bud 10 meristems of secondary floral axes can be recognized (Salazar-Garcia et al., 1998).

At the end of the process of induction there are no apparent macroscopic or anatomical changes in the apical buds of Hass, which remain with two secondary meristems (Salazar-Garcia et al., 1999). In the axillary buds, the situation differs in respect of the apical. At the end of the period of induction, the axillary buds only have two meristems of secondary axes floral, which constitutes the irreversible condition of the differentiation of the bud to flower (Salazar-Garcia et al., 1999).

The differentiation and floral development in the avocado generally occurs in autumn and winter, when the duration of the day is less than $12 \mathrm{~h}$ and the temperatures are relatively low.

The expansion of the inflorescence of the shoot is apparent in January, although the floral initiation occurs several months before (Salazar-Garcia et al., 1998). The carbohydrate reserves of the shoot could, in this way, be an important reserve for the development of the panicles, very demanding on energy from carbohydrates (Jackson and Sweet, 1972).

\subsection{Reproductive biology}

The avocado flower is bisexual having both functional male and female organs although separated in time through a synchronous protogynous dichogamous breeding system that prevents self-pollination and promotes outcrossing.

This mechanism prevents the autogamy (fusion of gametes formed in the same flower), since the flower although morphologically hermaphroditic, acts as unisexual.

Each perfect flower opens twice, the first functionally as a female flower with a white receptive stigma; then the flower closes and the following day the flower 
reopens functionally as a male flower, with the stigmas no longer receptive, and dehisced anthers.

The different avocado cultivars are classified in two groups (A or B) based upon their flowering behaviour (Fig. 8).

In the type A cultivars, the flowers open in the morning in the female stage (Fig. 10), close at midday and reopen the afternoon of the following day in the male stage (Fig. 9).

In the type B cultivars, the flowers open in the afternoon in the female stage, close in the evening and reopen the following morning in the male stage. Both of a type as the other remain closed during the night.

While some cultivars, as Waldin, Lula, Trapp, Taylor, among others, hold very well to this dicogamy, most of them have an overlap of these cycles, more or less extensive, making this phenomenon lose relevance.

For the case of the former, which bear or observe with accuracy the dicogamy, it is necessary to intersperse cvr. both types of cvr to increase the percentage of fertilization of the flowers.

It is really essential in the flowering of the Avocado the presence of pollinator agents at the time of flowering, therefore it is advisable to have hives in the crop.

\begin{tabular}{|c|c|c|c|}
\hline & Floral type & Morning & Afternoon \\
\hline \multirow{2}{*}{ Day 1} & $\mathrm{~A}$ & 우 & closed \\
\hline & B & closed & 우 \\
\hline & A & closed & 0 \\
\hline Day 2 & B & 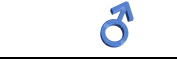 & \\
\hline
\end{tabular}

Figure 8: Timing of flowering for " $\mathrm{A}$ " and "B" flowering avocado types. 


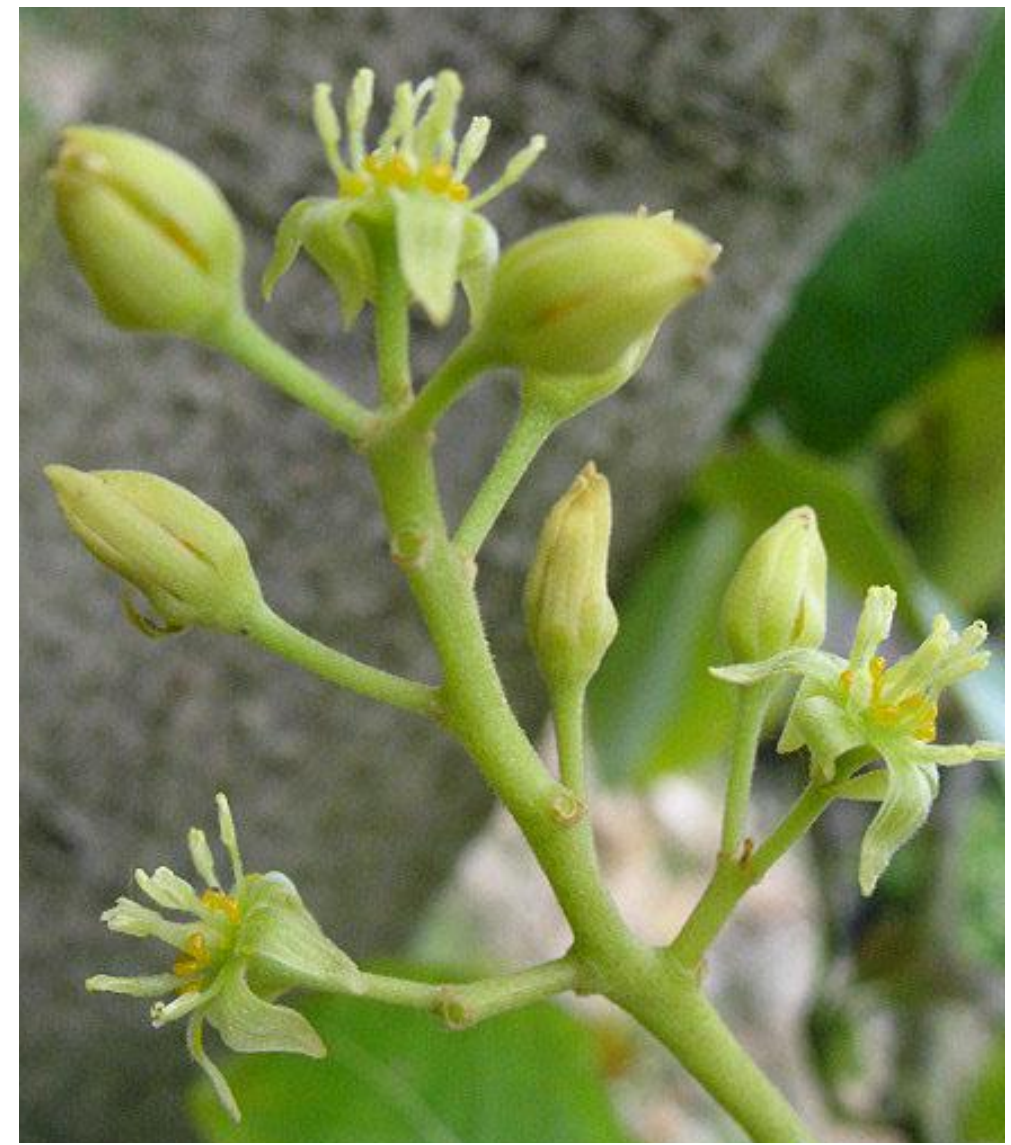

Figure 9: Male flower of avocado.

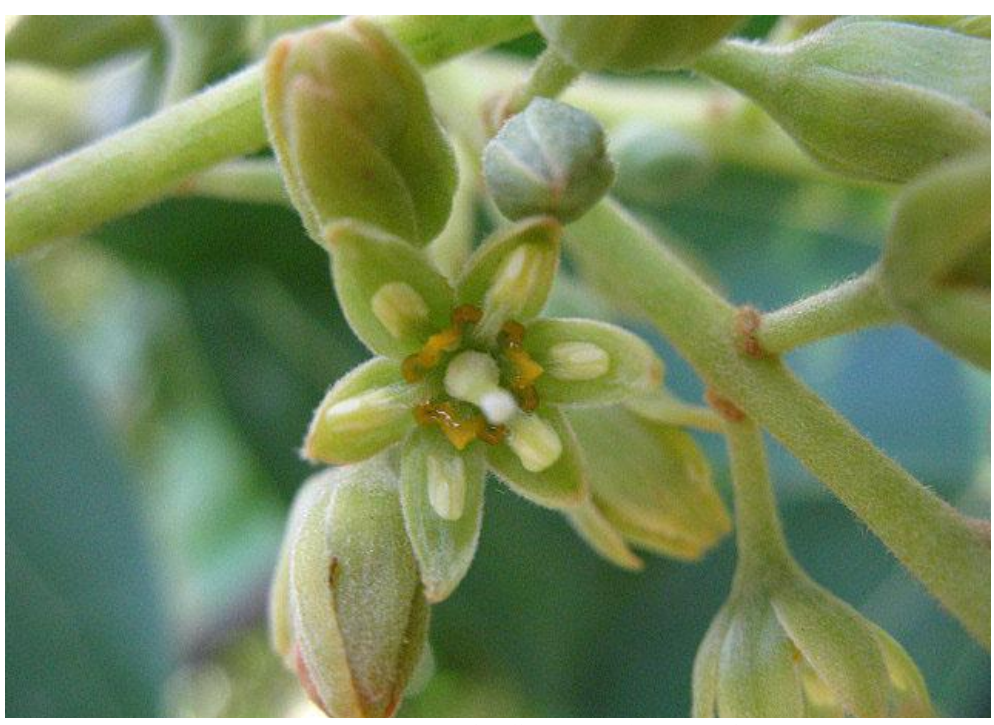

Figure 10: Female flower of avocado.

However, this floral behaviour is only observed under optimum climatic conditions because the cycle may be disrupted due to it is extreme sensitivity to environmental conditions particularly to cool temperatures (Stout, 1923; Lesley and Bringhurst, 1951; Bergh, 1969, 1974; Sedgley and Annells, 1981). 
For a thermal regime $25 / 16^{\circ} \mathrm{C}$ the flower behaves as described above. But for temperatures below $21^{\circ} \mathrm{C}$ and low light conditions, this floral behaviour can be reversed (Calabrese, 1992). Aubert and Lossois (1972) described 13 phenological stages in the phenology of shrub species, divided into three periods: 5 states for the vegetative phase, 5 states for flowering and 3 states for fruiting. However, such graphic scale does not clarify the evolution of such statements and does not include the avocado dicogamic process. Salazar-Garcia et al. (1998) raised for avocado macroscopic and a microscopic scale of 11 states from the closed bud to flower anthesis, linking the external appearance of the buds with the degree of development of the floral meristem. But even this scale reflects the evolution of the masculine and feminine flower states or fruit set states. Finally, Cabezas et al. (2003) conducted a state-type identification within the cycle of flowering and fruiting of avocado, considering morphological aspects of buds and flowering behavior regarding the presented dicogamia. The authors present a phenological model with 10 states, from dormant bud until tender fruit, based on the proposal of Aubert and Lossois (1972).

The flowering of this species is markedly prolonged, firstly because, the induction process in autumn lasts between two and three months in areas where environmental conditions are softer, and, secondly, that cold temperatures at the beginning of spring prolong flowering (Wolstenholme et al., 1990).

\section{FRUIT SET AND DEVELOPMENT OF FRUIT}

\subsection{Fertilization}

One of the main limitations in avocado production worldwide is the massive abscission of flowers and developing fruits, especially in the first two months following flowering. Sedgley and Alexander (1983) mention that the avocado trees can produce thousands of inflorescences, each of which may have more than 300 flowers, so that the total number of flowers per tree reaches over one million. Flowering contributes with a $8 \%$ to the total production of dry biomass in a complete growth cycle of an avocado tree and the process mobilizes nonstructural carbohydrates, reserves, and nutrients from leaves (Gazit and Degani, 2002). Romero (2011) found that in a year of high production, more than $100 \times 10^{3}$ flowers produced only 168 became a fruit. In other cases, such as adult trees 
Guatemalan race, fruit set barely reached between $0.001 \%$ and $0.23 \%$ of a total of more than $1.5 \times 10^{6}$ flowers (Gazit and Degani, 2002), and Lahav and Zamet (1999) indicates, for the cultivar Fuerte, that only $0.015 \%$ of flowers become ripe fruits. In short, the avocado is a species with very intense flowering in subtropical conditions where it may exceed $2 \times 10^{6}$ flowers of which only between $0.001 \%$ and $0.1 \%$ reach the fruit set (Salazar-García and Lovatt, 1998; Dixon and Sher, 2002; Can-Alonzo et al., 2005; Cossio-Vargas et al., 2007b, Garner and Lovatt, 2008).

\subsection{The physiological fruit drop}

In the cv Fuerte, Garner and Lovatt (2008) found a rapid drop of reproductive structures a few days after the greater part of the flowers had reached anthesis, and this does not seem to depend on the climatic conditions of cultivation, this is, tropical or subtropical (Romero, 2011; Zamet, 1999; Dixon et al., 2007a; Garner and Lovatt, 2008; Alcaraz et al., 2011). This pace of abscission has also been recorded in other species such as citrus, pear, mango, etc., which present a maximum of abscission during the first month after the anthesis, followed by a decline in the rate of abscission coinciding with the increase of fruit set.

Avocado fruit that fail to set can be divided into two groups: fruit resulting from flowers in which pollination occurred, but subsequent fertilization failed to take place (in some crops, pollination in the absence of fertilization is sufficient to stimulate development of the ovary into a mature, seedless fruit; this rarely occurs in avocado); and fruit resulting from flowers in which both pollination and fertilization occurred, resulting in a normal embryo and seed (Lovatt, 1990). Sedgley (1987) found that during the first week after the anthesis, $80 \%$ of the fruit drop came from pollinated but not fertilized flowers, while a month after the anthesis all fruit drops had been fertilized and showed a normal development of the embryo and endosperm. It is the study of this fruit drop fertilized that has deserved greater attention.

Under favourable conditions, avocado fruit set is very numerous, in these conditions, the plant during the first three or four weeks, causes the fruit drop to reduce the number of fruits. Later, during the summer, when the fruit has reached between $10 \%$ and $40 \%$ of its final size, a second abscission occurs (Whiley et al., 
1988; Wolstenholme et al., 1990).

The first abscission, i.e, which occurs once the fruits begin the fruit set, can be attributed to fruits with faults in the development of the seed, embryo abortion or death of the seed coat (Dixon and Sher, 2002; Kohne, 2004; Alcaraz et al., 2011), and the effect of environmental stress, particularly cold or heat (Gazit and Degani, 2002). The second fruit drop has been attributed to rapid utilization of carbohydrate reserves in the tree, so that the necessary photo-assimilated exceed the photosynthetic capacity of leaves and sink growth is limited by availability of metabolites (Gazit and Degani, 2002). Under these conditions only the fruits of greater vigor may persist on the tree (Laskowski, 2006). This competition can also be given between fruits development and vegetative growth (Bower y Cutting, 1988; Gazit and Degani, 2002). Fruit development strongly competes with roots and new shoots, reducing the reserves and suffering its drop (Wolstenholme and Whiley, 1995; Rosales et al., 2003). That is why Cossio-Vargas et al. (2007a) suggest that fruit drop marks the competition periods between vegetative growth and fruit development, directly affecting productivity.

Carbohydrate availability is considered a key factor in the fruit abscission. Thus, it has been shown that techniques for increasing carbohydrate levels result in an increased number of fruits and in bigger fruit (Wolstenholme et al., 1990; Lovatt, 1997). Conversely, young fruit abscission is the result of an insufficient supply of photoassimilate to the fruits due to high competition among those who have initiated development. This mechanism, however, is not incompatible with the hormonal regulation by which the fruits are demanding carbohydrates to ensure their survival (Paz-Vega, 1997; Lovat, 2006).

\subsection{Vegetative development-fruit development relationship}

This competition for carbohydrates can also occur between the growth of young fruits and vegetative growth (Bower and Cutting, 1988; Gazit and Degani, 2002). The development of the fruit strongly competes with roots and new shoots, reducing the reserves to a minimum at the time of the fruits drop (Wolstenholme and Whiley, 1995; Rosales et al., 2003). Cossio-Vargas et al., (2007a) have noted a significant of fruits drop that mark the periods of competition between the vegetative growth and the development of the fruit, directly affecting productivity. 
Previous studies (Paz-Vega, 1997; Salazar-Garcia et al., 1998; Salazar-Garcia and Lovatt, 2002) demonstrate that an abundant harvest uses a large amount of energy running out part of the reserves of the tree, so that the availability of resources is limited, significantly decreasing the intensity of flowering and significantly increasing the production of vegetative shoots. Lovatt (2006) found that the presence of the fruit inhibits the development of floral shoots and promotes the development of vegetative buds, increasing the number of buds that fail to sprout the next cycle. This difference is considered to be a determining factor in the establishment of the alternate bearing in the avocado (Dixon, 2007).

\subsection{Alternate bearing}

The low production of the avocado is the result of a series of events that occur along the reproductive development. The determination of the states which are sensitive to the abscission during the reproductive development is a prerequisite to investigate the physiological bases of the low production of the avocado and the development of agricultural strategies to increase its production. It has been demonstrated that it can be increased in the abscission of flowers and fruits set as a result of numerous factors, including extreme temperatures, nutritional deficiencies and genetic factors. Even under optimal conditions, the abscission of flowers and fruits in avocado is excessive.

Unfavourable climatic conditions during the critical period of flowering or fruit set (damage by cold, low or high temperatures, water availability) result in loss of flowers and fruits generating a low performance. In these conditions the reserves of the tree are used to a lesser extent and are available for the next production cycle in which the photoassimilatory system is greater, which is why it generates a greatest flowering, fruits set and harvest, giving rise to the imbalance in the production cycles (Lovatt, 2006). In Israel and California, this behaviour can be the result of a stress by high temperatures $\left(35-40^{\circ} \mathrm{C}\right)$ accompanied by $\mathrm{RH}$ very low and high winds (Lomas and Zamet, 1994).

In accordance with this, the productivity of many varieties of avocado, including cv. Hass, is characterized by the alternate bearing, a year of high harvest (year "on") is followed by another of low harvest (year "off") then another of high, and so on (Paz-Vega, 1997; Lovatt, 2006). A year "on" is determined by an intense 
flowering, high percentage of fruit set and high performance, while a year "off" is characterized by a low flowering, low percentage of fruit set and low performance (Paz-Vega, 1997; Lahav and Zamet, 1999; Bruwer and Robbertse, 2003; Dixon et al., 2007). Practices such as the maintenance of the fruits in the trees for long periods with the aim of increasing the dry matter and the oil content, intensify the alternation (Salazar-Garcia and Lovatt, 2000).

A study of Salazar-Garcia et al. (1998) showed that the reduction of the flowering is associated to a decrease of inflorescences $(13 \%$ of the total number of buds/branch) and a high production of vegetative shoots $(72 \%$ of total buds/branch). Thus, the flows of vegetative growth occur to a lesser extent in the year "on", while in the year "off" the growth is greater, and this difference is determinant of the alternation of crops in the avocado (Dixon, 2007). SalazarGarcia et al. (2006) found that only $13 \%$ of the total vegetative shoots produce floral shoots after a year "on", while after a year "off" $46 \%$ of them produces floral shoots.

Two scenarios have been presented to explain why the development of the fruit in a productive cycle inhibits the flowering and fruiting of the next cycle. The first is based on the higher demand of mineral nutrients, water and carbohydrates required for the processes of flowering, fruit set and ripening. A tree with a high fruit load in the year "on" exhausts the available reserves due to the greater extraction, and does not accumulate the necessary nutrients to sustain the following year a high intensity of flowering and a suitable load while trees in a year "off ", which presents a low harvest and higher production of vegetative structures, accumulate more reserves than nutrients to produce an intense flowering and a high performance in the next cycle (Paz-Vega, 1997).

It should be borne in mind that the magnitude of the alternation can vary, as stocks of carbohydrates depend on the environmental conditions and the handling of the crop. The second hypothesis is based on the reciprocity between the development of floral shoots and vegetative shoots for trees in a year "on" vs. trees in a year "off" is a clear indication that the growth regulators are playing an important role in the alternation of production cycles in the avocado, more than the availability of carbohydrates and nutrients (Paz-Vega, 1997; Lovatt, 2006). 
This hypothesis is based on the fact that the growth regulators which can be found in the seed of the developing fruits during a year "on" are in greater quantity, because a larger number of fruits is developed, favouring the vegetative growth during the next production cycle or year "off " to the detriment of the production of reproductive shoots (Paz-Vega, 1997).

Currently these hypotheses have been overtaken by the demonstration that in the years "on" the fruit suppresses the expression of the gene ortholog FLOWERING LOCUS T, PaFT (Ziv et al., 2014) from the end of October to the end of November, and only in the buds of the trees "off" is an expression of the floral identity transcripts PaAP1 and PaLFY, with significant variations detected since October and November respectively, in a similar way as it was demonstrated in the action of the fruit in the citrus fruits (Muñoz-Fambuena et al., 2011; 2012).

\subsection{Stimulation techniques of fruit set}

Under the hormonal point of view the application of gibberellins (gibberellic acid) to the flowers has been developed as an effective technique to increase production in species with difficulties of fruit set, as citrus fruits (El-Otmani et al. 2000). The application of GA increases the number of fruits that initiate the development, but if it is too high, the result an intense flowering, the not avoided abscission, is postponed. On the contrary, if the number of flowers is reduced, competition is low and the percentage of ovaries that begin their development, after the application of GA, not only increases but persists until the harvest.

An alternative technique is the ringing, cultural practice consisting in marking a complete ring of approximately $1 \mathrm{~mm}$ in width in the crust of the secondary branches of the tree, without affecting the xylem or delete the crust. Although it has been noted a hormonal effect derived from ringing, its priority action is through an improvement in the availability of carbohydrates as a result of the encouragement of the photosynthetic activity (Rivas et al., 2007).

As in the case of the applications of GA, the ringing in extreme conditions of high flowering is incapable of promoting the fruit set of species or varieties with parthenocarpic capacity, indicating that the high competition between bodies in development and the problems of pollination is the cause of the low capacity of the fruit setting of these plants. In these conditions, the availability of the fruit by 
carbohydrates is so committed that it is practically impossible to improve and that is why the ringing may prove to be ineffective. Also in this case the reduction of flowering it is necessary to increase the fruit set.

Finally, a pruning that can generate vegetative shoots that mature before the period of floral induction could ensure this in new leaves, allowing a number of buds to develop flowers even in conditions of high harvest (Mesejo et al. in preparation).

\section{THE ROLE OF CARBOHYDRATES IN SETTING AND FRUIT DEVELOPMENT}

In the avocado, soluble sugars of seven carbons (C7) are mostly the carbohydrate reserves (Liu et al., 1999). These sugars of seven carbons are unusual sugars in nature and have been found in only a few species of plants (Richtmyer, 1970). Other fruit species, such as apple trees, pear trees, olive trees, etc. will produce alcohol sugars of 6 carbons, as sorbitol and mannitol, which are mostly used for its transport. The avocado also produces a sugar alcohol, perseitol, a polihidroxi derivative of the reducing sugar D-manoheptulosa, also 7C (Liu et al., 1999), which is transported by the plant. Large quantities of these C7 sugars have been found in leaves, buds, trunks, and roots, and their concentration reaches higher values than that of the starch (Liu et al,.1999a), carbohydrate of reserve also in the avocado (Olivera and Priestley, 1988; Scholefield et al., 1985).

The fruit of avocado is characterized by a high respiratory rate during the development and maturation postharvest (Blanke and Whiley, 1995; Bower and cutting, 1988; Whiley et al., 1992), but little is known about the sugars that are used as substrate (Eaks, 1990; Luza et al., 1990). The highest rates in the respiratory avocado fruit have been observed during the early stages of the growth of the fruit (up to 12 weeks after anthesis), period of greater cell division. Subsequently, they decrease until reaching the lowest values just before the start of the ripening (Whiley et al., 1992).

Liu et al. (1999b) show a decrease in the concentration of C7 sugars in the skin and flesh of avocado after its storage at low temperature and after the maturation, suggesting the existence of an enzymatic mechanism of metabolism of these.

The fruit of avocado does not mature in the tree (Bower and Cutting, 1988). The 
possibility that a reduction in the concentration of sugars is prerequisite for its maturation has been raised. Only when the fruit is separated from the tree and the contribution of this from the sources, therefore, stops and you can start the process of maturation. The sugars of $7 \mathrm{C}$, D-mannoheptulose and perseitol, could thus play a role in the control of the maturation, but the fact that the D-mannoheptulose is a powerful inhibitor of the hexokinase and therefore of the respiratory glycolytic processes complicates this interpretation (Board et al., 1995; Leon and Sheen, 2003).

On the other hand, the mannoheptulose might be necessary in order to encourage the export of sugars and its load in the phloem, thus ensuring the growth of the fruit. Later, the metabolism of the mannoheptulose, in another place of the tree can involve a ketoreductase and the formation of perseitol. Both the mannoheptulose and the perseitol are products of the assimilation of $\mathrm{CO}_{2}$ in the leaves, and a recent study suggests that in this body the mannoheptulose is formed as a phosphorylated product of the sedoheptulose-1,7 diphosphate, track condensation of the dihydroxyacetone phosphate and erythrose 4-phosphate (Liu et al., 1999; 2002).

\section{HORMONAL CONTROL OF FRUIT SET AND FRUIT DEVELOPMENT}

In the avocado, competition between young fruits in development and those with the vegetative growth of spring has been related to the reduction of the fruiting (Kalmar and Lahav, 1976; Köhne, 1987; Bower, 1990). At the same time, as said, the fruits set reduce the intensity of vegetative development in the sprouting of summer and autumn (Whiley et al., 1988). In addition, fruits compete for resources among themselves affecting, this way, their final size (Wright, 1989). All these processes of nutritional type are, however, hormonally regulated (Naylor, 1984).

In some species of fruit of perennial leaf in which the intensity of flowering can be reduced easily, the partial inhibition of flowering has been shown to be an effective mechanism to reduce competition among flowers in development and improve the fruit set, and this even for species/cultivars parthenocarpic. Thus, in mangos, oranges, tangerines and lemons, the application of gibberellic acid $\left(\mathrm{GA}_{3}\right)$ 
in autumn, during the time of floral induction, significantly reduces the intensity of flowering favouring the fruit set (Monselise and Havely, 1964; Chacko et al, 1972; Nir et al, 1972; Guardiola et al, 1977; Oohata Iwahory, 1981; Nuñez-Elisea and Davenport, 1991). This effect in citrus fruits has been associated with the reduction of the gene expression of the gene FLOWERING LOCUS T (FT) (Muñoz-Fambuena et al., 2012b) and with the reduction of the sprouting (Guardiola et al., 1984, Garcìa-Luis et al, 1986; Muñoz-Fambuena et al, 2012b), and leads to a redistribution of the sprouting increasing the percentage of inflorescences with leaves and decreasing the leafless. Both results, reduction in flowering and increase of inflorescences with leaves, as a whole, increase the percentage of flowers that exceed the fruit set and the number of fruits that initiate the development and reach the maturation.

In the avocado similar results have been achieved by inhibiting the flowering (Salazar and Lovatt 2000), but its effect on the fruit set and the final harvest has not been studied.

A recent research has shown that the $\mathrm{GA}_{3}$ altered the phenological stages and morphology of the inflorescence (Salazar-Garcia and Lovatt, 1998). Implemented in November, at the time of floral induction, gibberellic acid reduces the intensity of flowering due to the production of inflorescences partially formed, each with a smaller number of flowers, but with the development of an accelerated vegetative shoot. The results suggest that the possibility of applying it in November in an "off" year would equal the alternation by reducing the formation of secondary axes of shoots of inflorescences. Subsequent applications (December or January) would not affect the inflorescences or the number of flowers, but accelerate the development of vegetative shoot in the apex of the indeterminate inflorescences. Due to the advanced development caused by the implementation of $\mathrm{GA}_{3}$, the leaves become sources of photo assimilates in fruit set, instead of sinks of competition (Blanke and Lovatt, 1998). Therefore, the foliar applications of $\mathrm{GA}_{3}$, both early and late, provide strategies for the handling of the productivity of the avocado. 
II. HYPOTHESIS 


\section{HYPOTHESIS}

In accordance with the foregoing, our working hypothesis is that in avocado flowering intensity is responsible for fruit set and initial development of the fruit.

To prove it, we have determined:

1. The influence of the flowering intensity in the time course of carbohydrate content during the first flower drop.

2. The influence of number of flowers on the rate of fruitlet abscission.

3. Hormonal control of the process. Time course of auxin, gibberellins and cytokinins.

4. Percentage of fruit set.

So we have designed a series of experiments in order to:

- Reduce flowering.

- Reduce competition between flowers and vegetative growth.

- Promote fruit set. 


\section{MATERIALS AND METHODS}




\section{MATERIALS AND METHODS}

\section{VEGETAL MATERIAL}

The experiments were carried out in commercial orchards of avocado (Persea americana Mill.) cv. Hass (group A flowering), located in Torrent and Llaurí (Valencia), Spain, and in Caronia Marina (Messina), Italy. Adult trees (5-8 years), planted at a distance of $5 \times 6 \mathrm{~m}$., appearing uniform, in good sanitary condition and with proper agronomic management throughout the period of the experiment, were used.

In Llaurí 8 trees arranged in random, 8-year-old grafted on rootstock 'Duke 7' were used. In this plantation there were cv. Fuerte trees (group B flowering) in a ratio of $1: 10$, to ensure pollination.

In Torrent 36 trees arranged randomly, 5 years old, grafted on rootstock 'Toro Canyon' were used. In this plantation there were cv. Fuerte trees, in proportion $1: 10$, to ensure pollination.

In Caronia Marina 8 trees arranged randomly, 5 years old, grafted on rootstock 'Toro Canyon' were used. Also, here pollination was ensured with cv. Fuerte trees in a ratio of $1: 10$.

\section{EXPERIMENTAL DESIGN}

\subsection{Intensity of flowering vs. fruit set}

The study was conducted in Torrent during the 2015-16 campaign. Dates of treatments and sampling are presented in Table 1.

For this experiment 6 trees were selected randomly, during the time of floral induction (phenological state $010 \mathrm{BBCH}$ scale Alcaraz et al, 2013) foliar applied $\mathrm{GA}_{3}$ at a concentration of $50 \mathrm{mg} \mathrm{l}^{-1}(51 /$ tree $)$, which a nonionic surfactant at a concentration of $0.01 \%$ was added. The application was made with tank at a pressure of 25-30 atm, wetting to dripping trees. Six Other trees with similar conditions were selected as control.

Three branches of the same size, approximately, and two years old, were randomly selected from each of the trees, south, northeast and northwest oriented, in order to count their sprouting and flowering nodes at the time of floral 
differentiation (phenological stage 519 of $\mathrm{BBCH}$ scale). On each count date buds were classified as no sprouted (NS), incipient (I) and sprouted (S) (Figure 11).

In addition, 12 panicles were randomly selected in winter, before sprouting, from each treatment, randomly distributed among the 6 trees, which were counted the number of flowers.

At the time of anthesis (phenological stage $610 \mathrm{BBCH}$ scale) the status of each type of node was evaluated, and the number of flowers, as the result of multiplying the number of knots that had been observed in a panicle, was calculated by the average number of flowers per panicle. In this case the results were also expressed by 100 nodes. In addition, from 12 panicles per treatment, the evolution of the shoot developed length of vegetative terminal bud is periodically evaluated.

\subsection{The exogenous control of the abscission of reproductive organ}

5 treatments (table 2) were conducted in anthesis: gibberellic acid $\left(\mathrm{GA}_{3}\right)$ at a concentration of $50 \mathrm{mg} \mathrm{l}^{-1}$, paclobutrazol (PBZ) at a concentration of $50 \mathrm{mg} \mathrm{l}^{-1}$, ringing $(\mathrm{RN})$, and combinations of gibberellic acid + ringing $\left(\mathrm{RN}+\mathrm{GA}_{3}, 50 \mathrm{mg} \mathrm{l}\right.$ $\left.{ }^{1}\right)$ and paclobutrazol + ringing $\left(\mathrm{RN}+\mathrm{PBZ}, 50 \mathrm{mg} \mathrm{l}^{-1}\right)$. In other trees the same treatments were performed after 15 days, when the fruit had a diameter of $3 \mathrm{~mm}$ (state $711 \mathrm{BBCH}$ ). For each treatment four trees were used. The experiments were conducted for two consecutive years in Llaurí, Torrent and Caronia Marina. In Llaurí and Caronia Marina treatments were performed individually at the inflorescence; in Torrent on the entire tree.

Weekly fruit set was evaluated by counting the average number of fruits per panicle of 8 panicles per treatment, and development of the average length of 10 shoots developed from vegetative terminal bud of the panicle.

At the same time fruits and shoots developed from treated panicles were sampled. 


\begin{tabular}{cc}
\hline Sampling date & Phenological stage \\
\hline 19 - Nov - 2015 & 010 \\
29 - Febr - 2016 & $511-610$ \\
11 - April - 2016 & 610 \\
19 - April - 2016 & 617 \\
26 - April - 2016 & 711 \\
02 - May - 2016 & 715 \\
13 - May - 2016 & 716 \\
\hline
\end{tabular}

Table 1: Sampling dates and phenological growth stages at sampling in

Torrent (Valencia), Spain, for flowering and fruit set evaluation. Dates of treatment: 19/11/2015 $11 / 04 / 2016$ and 26/04/2016.

\begin{tabular}{c|c|c|c}
\hline TREATMENTS & - & $\mathrm{GA}_{3}$ & PBZ \\
\hline- & 4 & 4 & 4 \\
\hline + RINGING & 4 & 4 & 4 \\
\hline
\end{tabular}

Table 2: Treatments and number of trees per treatment in Torrent (Valencia), Spain, used in the experiment to improve fruit set. Dates of treatment: 11/04/2016 and 26/04/2016.

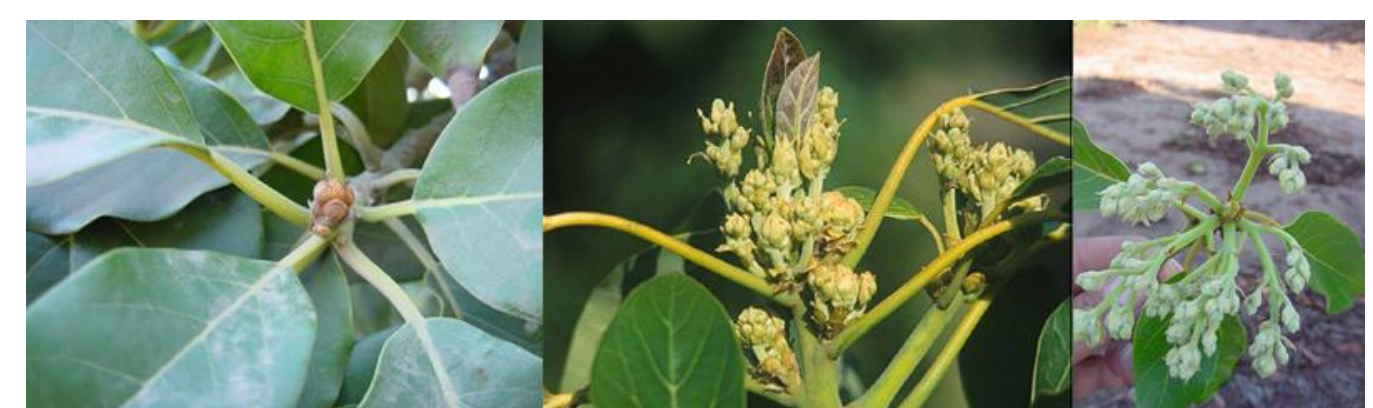

Figure 11: Classification buds: no sprouted (left), incipient (centre) and sprouted (right).

\subsection{Vegetative development vs. Reproductive development. Hormonal and nutritional control}

The study was carried out in Llaurí and Caronia Marina. Trees treated in both fields were evaluated determinate panicles (Figure 12) and indeterminate panicles (Figure 13). From 10 flower shoots (which included several thyrsus), divided into 
two trees per treatment, the time course of the first physiological flower drop was weekly evaluated (Tables 3 and 4). For this, the inflorescence is introduced into a bag and minimally waved to collect all the flowers that had started the process of abscission. The collected flowers, were carried to the laboratory at low temperature $\left(7^{\circ} \mathrm{C}\right)$, counted and frozen for lyophilization. Then they were triturated for further analysis of carbohydrates and hormones.

In the latest dates, when no more flowers of the tirso were exuded, fruits set and leaves were taken. They were taken to the laboratory and handled like flowers. At the same time the length of the terminal shoot was measured.

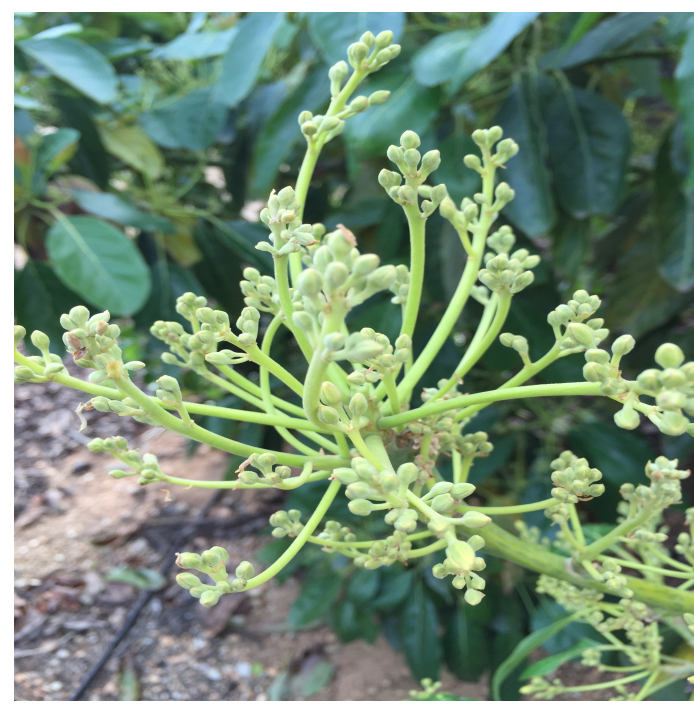

Figure 12: Determinate panicle.

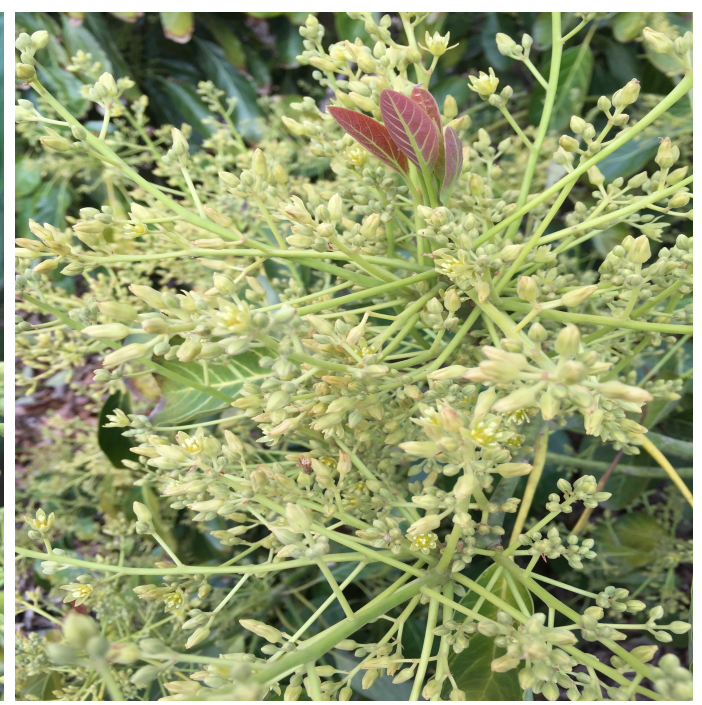

Figure. 13. Indeterminate panicle.

\begin{tabular}{cc}
\hline Sampling date & Phenological stage \\
\hline 31-March-15 & $518 / 113 \mathrm{BBCH}$ \\
09 -April -15 & $610 \mathrm{BBCH}$ \\
16 -April -15 & $617 \mathrm{BBCH}$ \\
23 -April- 15 & $618 \mathrm{BBCH}$ \\
28 -April -15 & $711 \mathrm{BBCH}$ \\
04 -May -15 & $712 \mathrm{BBCH}$ \\
11 -May -15 & $713 \mathrm{BBCH}$ \\
15 -May -15 & $715 \mathrm{BBCH}$ \\
29 -May -15 & $716 \mathrm{BBCH}$ \\
08 -June -15 & $717 \mathrm{BBCH}$ \\
13 -July -15 & $719 \mathrm{BBCH}$
\end{tabular}

Table 3. Sampling dates and phenological growth stages at sampling in Llaurí (Valencia), Spain, for the evaluation of fruitlet abscission. Date of treatment: 09/04/2015. 


\begin{tabular}{cc}
\hline Sampling date & Phenological stage \\
\hline 05-April-15 & $518 / 113 \mathrm{BBCH}$ \\
04-May-15 & $617 \mathrm{BBCH}$ \\
14-May-15 & $618 \mathrm{BBCH}$ \\
25-May-15 & $711 \mathrm{BBCH}$ \\
04-June-15 & $712 \mathrm{BBCH}$ \\
26-june-15 & $715 \mathrm{BBCH}$ \\
20-July-15 & $719 \mathrm{BBCH}$
\end{tabular}

Table 4: Sampling dates and phenological growth stages at sampling in Caronia Marina (Messina), Italy, for the evaluation of fruitlet abscission.

Date of treatment: 25/05/2015.

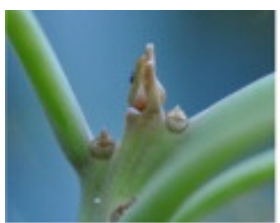

Stage 010

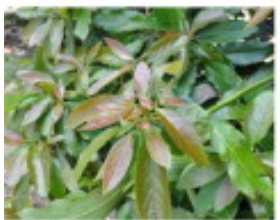

Stage 119/315

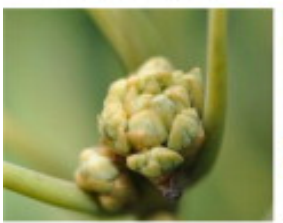

Stage 513

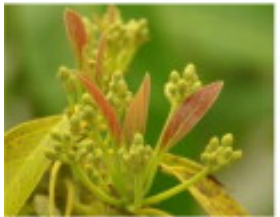

Stage 518/113

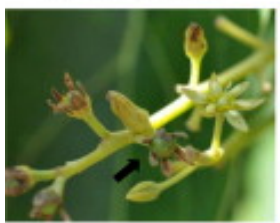

Stage 711

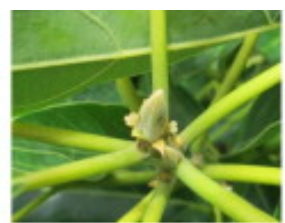

Stage 019

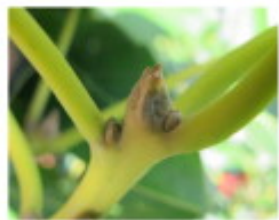

Stage 510

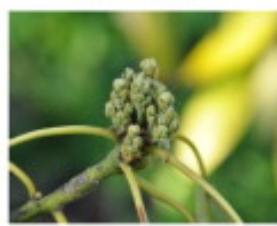

Stage 514

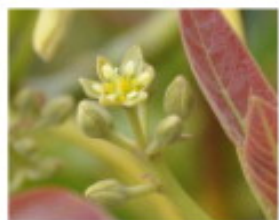

Stage 610 Female

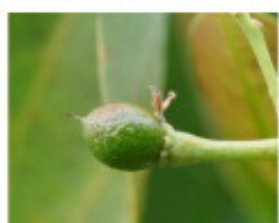

Stage 712

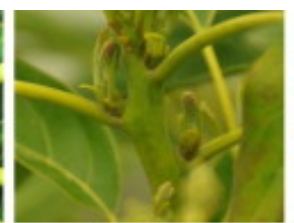

Stage 110

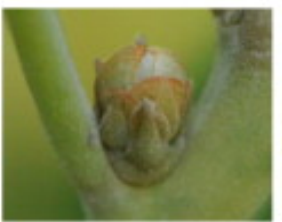

Stage 511

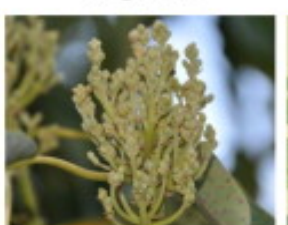

Stage 515

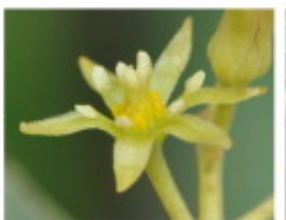

Stage 610 Male

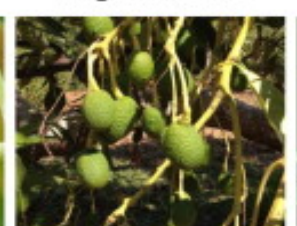

Stage 715

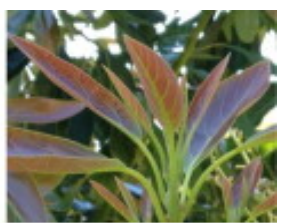

Stage 115

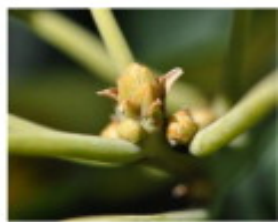

Stage 512

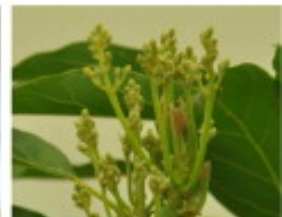

Stage $517 / 110$

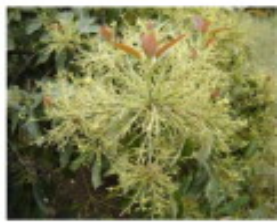

Stage 617

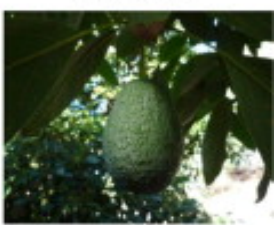

Stage 719

Figure 14: Some of the primary and secondary phenological growth stages of avocado tree according to BBCH-scale. 


\section{ANALYSIS OF CARBOHYDRATES}

Analysis of soluble sugars is performed according to the protocol Tesfayac et al., (2012) with certain modifications. Sugar determination, powdered samples [100 mg dry weight (DW)] were extracted with $1.0 \mathrm{ml} \mathrm{80 \%} \mathrm{(v/v)} \mathrm{ethanol.} \mathrm{For} \mathrm{recovery}$ purposes, a known amount of mannitol (Sigma Chemical Co., Madrid, Spain), a sugar absent in the phloem sap, was added to the extracts as an internal standard. The extracts were then incubated at $80^{\circ} \mathrm{C}$ for $5 \mathrm{~min}$ and centrifuged at $15,000 \times \mathrm{g}$ for $10 \mathrm{~min}$. The supernatant was removed and the pellet re-extracted twice, as above. The supernatants were evaporated in vacuum at $45^{\circ} \mathrm{C}$ to $0.5 \mathrm{ml}$, and residues were re-dissolved in $1.0 \mathrm{ml}$ water and purified sequentially by cation exchange Dowex 50×(8-100 mesh; Sigma Chemical Co., Madrid, Spain) and anion exchange Dowex $1 \times(4-400$ mesh; Sigma Chemical Co., Madrid, Spain) chromatography. The 1.0-ml columns were pre-equilibrated with $2 \mathrm{M} \mathrm{HCl}$ and 1 $\mathrm{M} \mathrm{Na} \mathrm{CO}_{3}$, respectively, and washed with 50 column volumes of water before sample application. The elutes ( $1.0 \mathrm{ml}$ extract and $2 \mathrm{ml}$ water washings $)$ were then passed through a C18 Sep-Pak cartridge (Waters Millipore, Barcelona, Spain). An aliquot of $0.5 \mathrm{ml}$ was acidified with $25 \mu \mathrm{l}$ of $0.1 \mathrm{M} \mathrm{H}_{2} \mathrm{SO}_{4}$ and filtered through a $0.45 \mu \mathrm{m}$ membrane (Waters Millipore, Barcelona, Spain). Sugars were analysed using a HPLC Spectra System ${ }^{\circledR}$ (Spectra, San Jose, CA, USA) connected to a differential refractometer (Spectra R150), vacuum pump (Spectra P2000), and ChromQuest ${ }^{\circledR}$ Chromatography Data System for Windows NT (Thermo Quest Inc., San Jose, CA, USA). Twenty-microlitre aliquots of the filtered extracts were injected into a Hypersil ${ }^{\circledR}$ APS-2 $(250 \times 4.6 \mathrm{~mm})$ column (Thermo Quest Inc., San Jose, CA, USA). The column was kept at $25^{\circ} \mathrm{C}$, and pure $\mathrm{mQ}$ water was used as

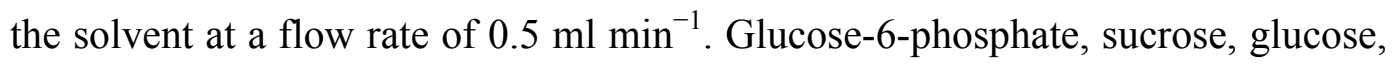
fructose and perseitol were identified according to their retention times. Sugar quantification was performed using peak area calculation related to regression curves for known concentrations of sugars (Sigma Chemical Co., Madrid, Spain), taking into account the recovery of each sample. The effectiveness of the extraction was ascertained by the amount of mannitol used as an internal standard. 


\section{HORMONAL ANALYSIS}

Hormonal analysis is performed from $50 \mathrm{mg}$ of lyophilized material. Duplicate aliquots of each sample $(50 \mathrm{mg})$ were extracted with $80 \%$ methanol: acetic acid $1 \%(\mathrm{v} / \mathrm{v})$ in the presence of specific internal standards (labeled hormones deuterium to quantify losses of each hormone inherent extraction process) [O1Chemim Ltd - Olomouc, o Cambridge Isotope Lab - Andover]: [17, $\left.17-{ }^{2} \mathrm{H}\right]$ GAn, $\left[{ }^{2} \mathrm{H}_{5}\right]$-IAA y $\left[{ }^{2} \mathrm{H}_{6}\right]$-ABA). These standards were added to quantify each of different gibberellins (GA's), indoleacetic acid (IAA) and abscisic acid (ABA). In the case of the cytokinins, them forms deuteradas of the trans-zeatina (D-tZ), dihidro-zeatina (D-DHZ) e 2-isopentenil-adenina (D-iP) are used as standards internal.

To recover the acid fraction where the GA's, el IAA and ABA are located, extracts passed consecutively through columns HLB (Waters Cromatografía, S.A., Barcelona, Spain) reverse phase, MCX (cation exchange) and WAX (ion exchange) (Oasis $30 \mathrm{mg}$, Waters Cromatografía S.A., Barcelona, Spain) as described in Seo et al. (2011). For recovery of the basic fraction where cytokinins are located, the samples passed first through an HLB cartridge (elution CH3CN80: acetic acid 1\%) and then through an MCX column. Samples were taken to dryness in a rotary evaporator.

The dry residue was dissolved in 5\% acetonitrile and $1 \%$ acetic acid, and hormones were separated using ultra-chromatography in reverse phase (UPHL) through a column RP-MS Accucore 2,6 $\mu \mathrm{m}$ (50 mm x 2,1 i.d.: Thermo Fisher Scientific Inc., Waltham, MA, EEUU) with an acetonitrile gradient from 5 to $50 \%$, after which they were detected and analyzed in a spectrometer mass/mass (Q-exactive Orbitrap detector, Thermo Fisher Scientific Inc., Waltham, MA, EEUU). The final hormone concentrations of the extracts were determined using the calibration curves made previously. The interpretation of the results is performed by they programs Xcalibur 2.2 SP1 build 48 and TraceFinder. 


\section{STATISTICAL ANALYSIS}

In all cases randomized experiments were designed, using the tree as a unit of study and a tree repetition.

The analysis of variance with a level of confidence was applied to the results $(P \leq 0.05)$. For the analysis of interactions between treatments and dates analysis of double factorial variance were made. For the separation of means the test of Student-Newman-Keuls was applied using the computer program StatGraphics Centurion. For the analysis of interactions between treatments and dates the double factorial variance analysis were performed. When it was necessary the transformation arc sen $\vee_{p}$ were applied to normalize the population. 


\section{RESULTS}




\section{RESULTS}

\section{INTENSITY OF FLOWERING-FRUIT SET}

\subsection{Reduction of the flowers number by applying $\mathbf{G A}_{3}$}

Foliar application of $\mathrm{GA}_{3}$ at a concentration of $50 \mathrm{mg}^{-1}$ for the period of floral induction (phenological stage 010 of $\mathrm{BBCH}$ scale), significantly delayed the sprouting of cv. Hass. Thus, 91 days after treatment, control showed a significantly higher percentage of buds in the most advanced state, fully developed, that the treaty (50\% and 30\%, respectively) (Figure 15), and a lower percentage of them no sprouted buds (35\% and 50\% respectively) (Figure 15). However, the number of buds in the intermediate state (I), incipient, was not influenced by the treatment.

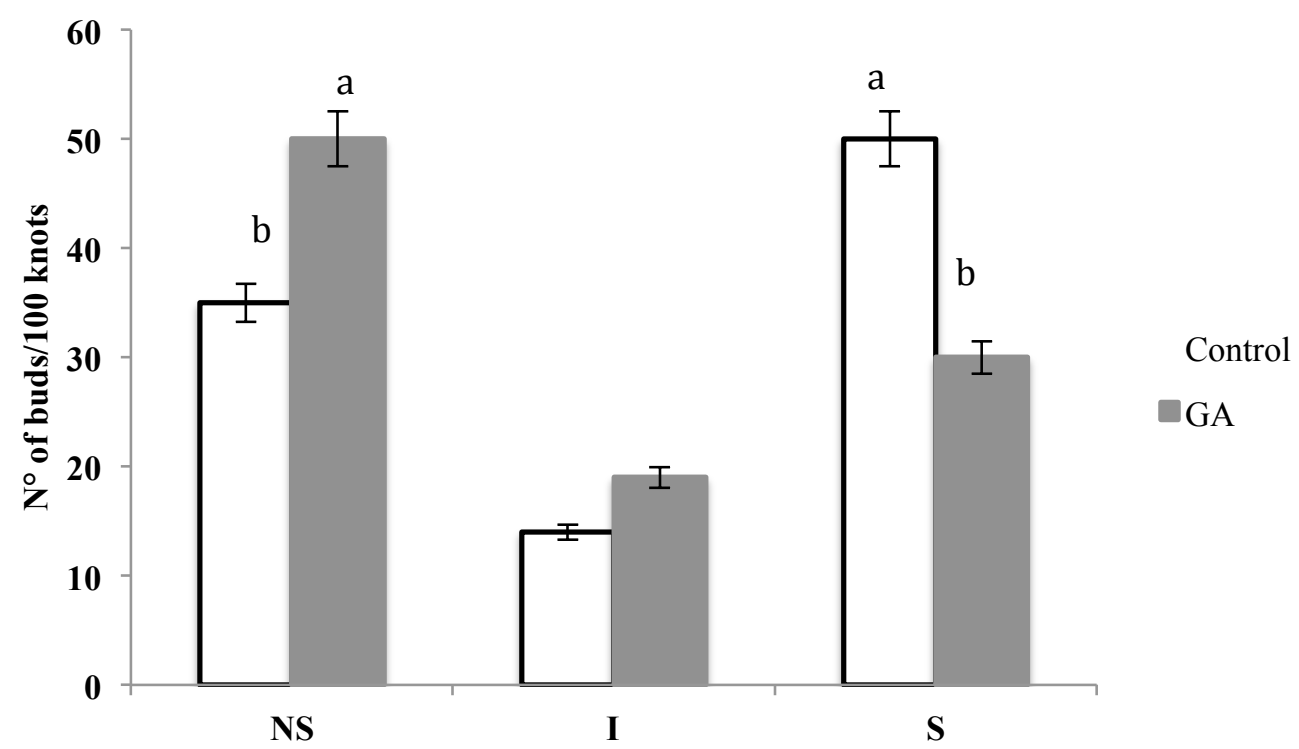

Figure 15: The influence of $\mathrm{GA}_{3}\left(50 \mathrm{mg} \mathrm{l}^{-1}\right)$ applied in the floral bud inductive period on bud development of avocado cv. Hass. Date of treatment: November 29, 2015. Evaluation 91 days after treatment. The horizontal axis represents the phenological stage bud at the time of evaluation (NS: no sprouted; I: incipient; S: sprouted). Values expressed in number of buds per 100 knots. Vertical bars indicate standard error. Different letters for the same state of the bud indicate significant differences $(P \leq 0.05)$.

Subsequent evaluations showed a progressive decrease in the number of no sprouted knots in both treatments, reaching zero in both cases 130 days after treatment, in the vegetative development when, in addition, they had the same number of fully developed buds (which on average was $50 \%$ in the case of trees treated with GA and 54\% in the control). 
These results reflect a temporary effect of GA in delaying sprouting, which is lost over time.

The GA also modifies flowering. So, 130 days after treatment, the treated trees have $48.3 \%$ fewer flowers than the control (Figure 16). Considering that in this evaluation the number of developed shoots were not affected by the GA, the fewer flowers obtained by the treatment was a consequence of reducing the number of flowers per panicle. So while the panicles of control trees have, on average, 341 flowers per panicle, the treaty had only 267 . In this case the direct effect of GA reducing the number of flowers per panicle also reached statistical significance.

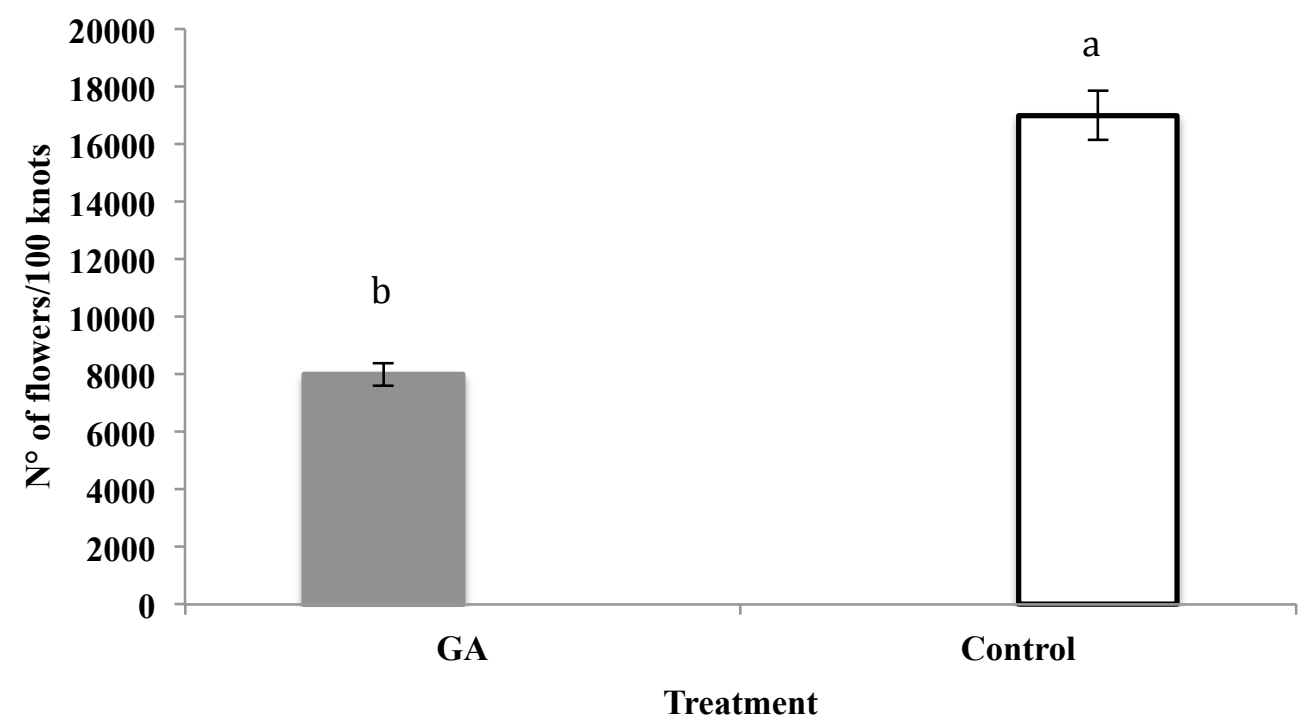

Figure 16: The influence of $\mathrm{GA}_{3}\left(50 \mathrm{mg} \mathrm{l}^{-1}\right)$ applied in the floral bud inductive period on flowers number of avocado cv. Hass. Date of treatment: November 29, 2015. Values calculated from the average number of flowers per panicle multiplied by the average number of knots developed per 100 knots. Vertical bars indicate standard error. Different letters indicate significant differences $(P \leq 0.05)$ between treatments.

Considering that in avocado panicle may have (or not, abortion) terminal vegetative bud, the effect of GA also reached the development of the shoot emerged from it. Thus, 140 days after treatment significant differences in the length of these shoots were observed, which remained constant until the end of the study period (Figure 17). At this time, while shoots of treated trees were $4.7 \mathrm{~cm}$, the controls barely reached $3.4 \mathrm{~cm}$. Seven days after the first had grown by $32 \%$, while the second had done $15 \%$. These differences remained virtually constant over time, and at the end of the study (185 days after treatment) sprouts treated trees were $2.25 \mathrm{~cm}$ longer than the controls (Figure 17). 


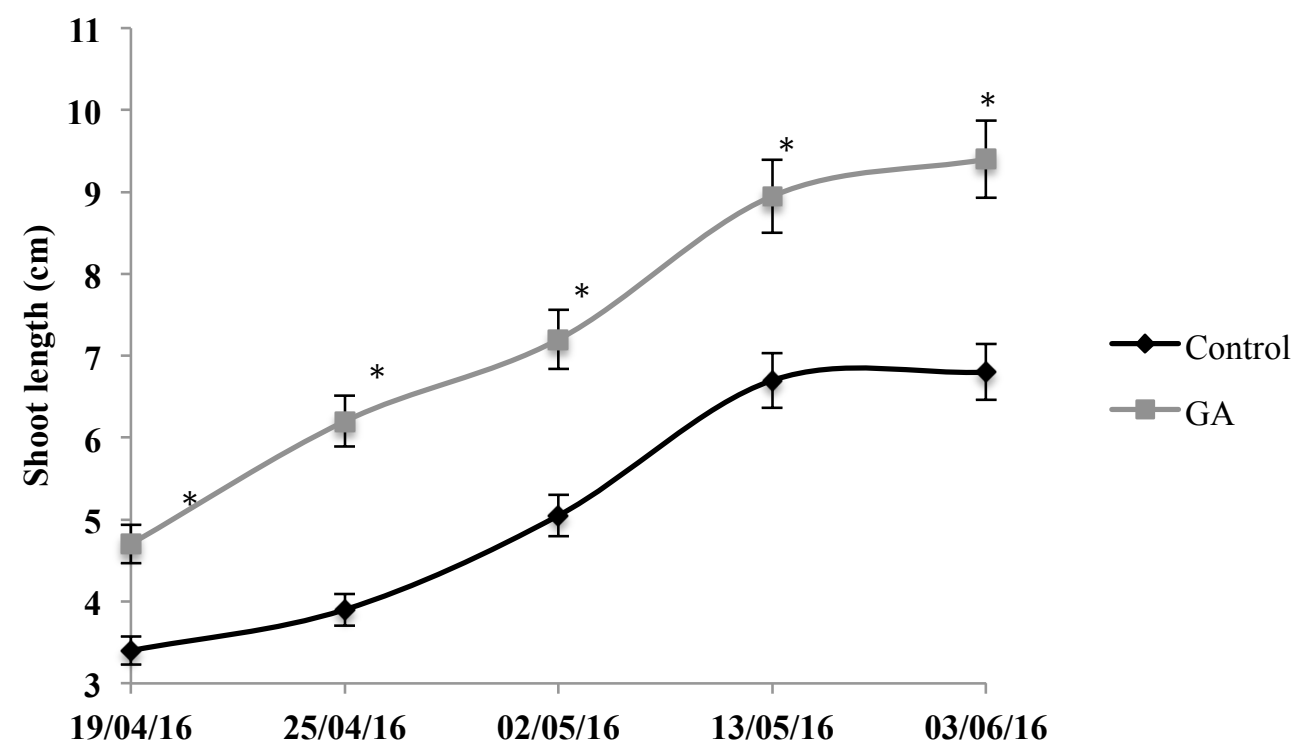

Figure 17: The influence of $\mathrm{GA}_{3}\left(50 \mathrm{mg} \mathrm{l}^{-1}\right)$ applied in the floral bud inductive period (November 29,2015 ) on the length of developed shoot from vegetative terminal bud of the panicle cv. Hass. Each point is the average of 10 shoots. Vertical bars indicate standard error. The * indicates significant differences for the same date $(P \leq 0.05)$.

Fruit set was also temporarily altered by the treatment and 145 days after it, the GA had increased the number of fruits per panicle by $90 \%$ compared to control. These differences were more notable 152 days after treatment, when the first had 19 fruits per panicle, on average, the latter only had 2 (Figure 18).

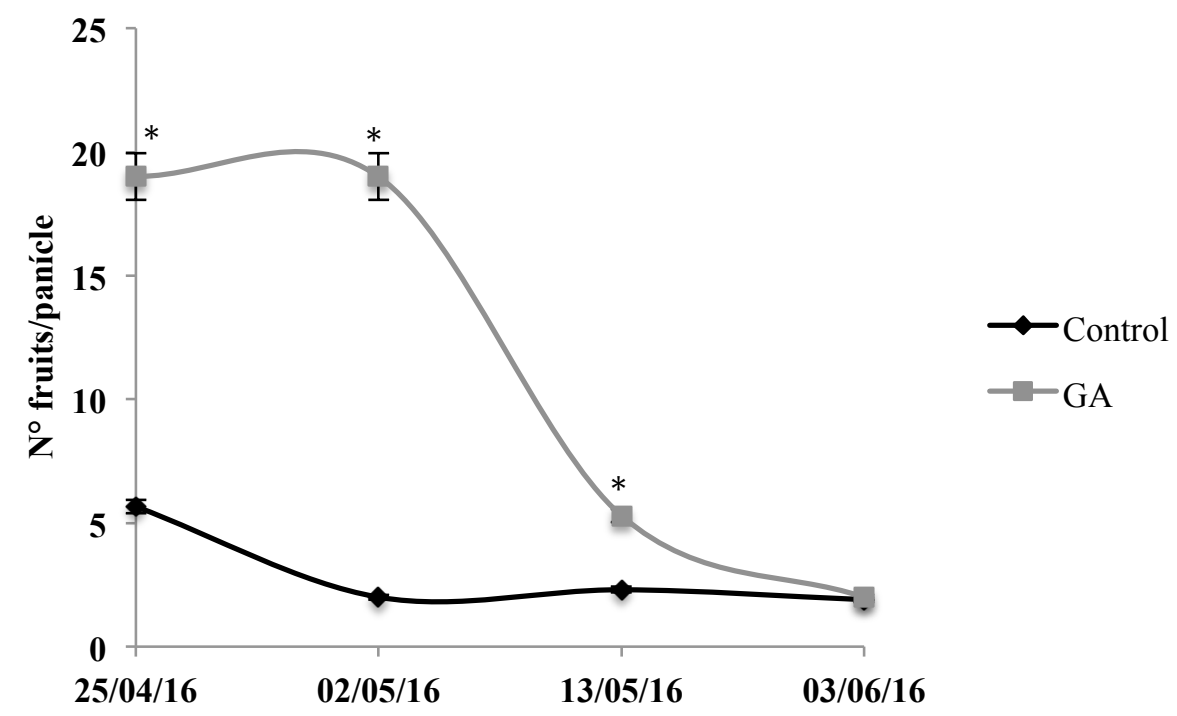

Figure 18: The influence of $\mathrm{GA}_{3}\left(50 \mathrm{mg} \mathrm{l}^{-1}\right)$ applied in the floral bud inductive period on the number of fruit set per panicle and its time course in cv. Hass. Date of treatment: November 29, 2015. Vertical bars indicate standard error. The * indicates significant differences for the same date $(P \leq 0.05)$.

It is notable that the largest number of fruits set per panicle during the first dates 
on trees treated with GA corresponds to fewer flowers (Figure 16), and to a further development of shoots from the terminal bud of the inflorescence (Figure 17).

It is also interesting to note that, while differences in the number of fruits set were lost over time to match (Figure 18), those found along the length of the shoots were kept until the end (Figure 17). These results therefore suggest that fruit set of this species is not conditioned by phenomena of competition between the vegetative development of the terminal bud of the panicle and its own reproductive development.

\section{VEGETATIVE DEVELOPMENT- REPRODUCTIVE DEVELOPMENT RELATIONSHIP. HORMONAL AND NUTRITIONAL CONTROL}

\subsection{The time course of flower abscission}

The time course of flowers abscission in avocado cv. Hass, under the conditions

of our experiment is presented in Figure 19. In the two localities, percentage curves of flower abscission showed a similar pattern, differing only in magnitude. Overcome anthesis, abscission rate was fast and progressive.

In Llaurí (Figure 19 A), 7 days after anthesis (DAA) (state $617 \mathrm{BBCH}$ ) flowers drop was higher in indeterminate panicles $(35.5 \%)$ than in determinate panicles (17.5\%). Fourteen DAA (state $618 \mathrm{BBCH}$ ) abscission was $82.7 \%$ and $75.8 \%$, respectively. Twenty DAA (state $711 \mathrm{BBCH}$ ) flowers drop was $100 \%$ in both types of panicle.

In Caronia Marina (Figure $19 \mathrm{~B}$ ), the May 4 (state $617 \mathrm{BBCH}$ ) abscission of flowers was $73.4 \%$ in indeterminate panicles and $69.5 \%$ in determinate panicles, without significant differences between them. In the phenological state 618 BBCH scale (May 14) abscission was $96.9 \%$ in the first and $98.9 \%$ in the second. On May 25, corresponding to state $711 \mathrm{BBCH}$ scale, as in the case of Llaurí, flowers drop was $100 \%$ in the two types of panicle.

In view of this, the flowers abscission anticipated in Caronia Marina if compared to Llaurí, especially in indeterminate panicles. Thus, in the state $617 \mathrm{BBCH}$ scale, while in Caronia Marina it had dropped $73.4 \%$ of flowers in Llaurí it had just dropped $35.5 \%$. In the determinate panicles abscission was $69.5 \%$ and $17.5 \%$, respectively (Figure 19). 


\section{BBCH}

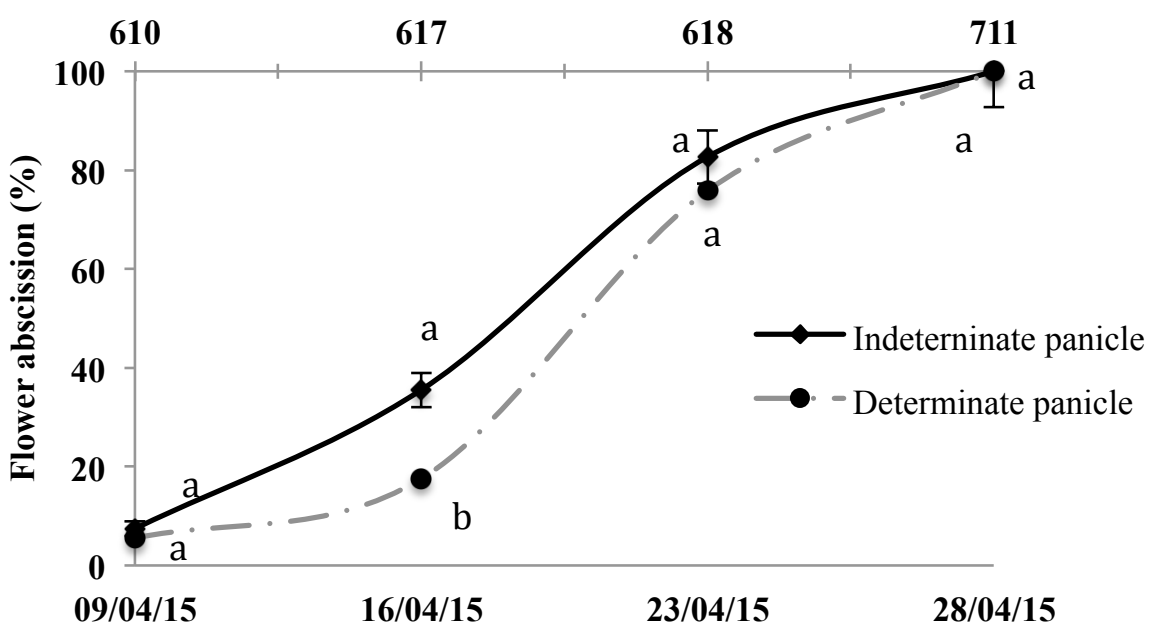

A

BBCH

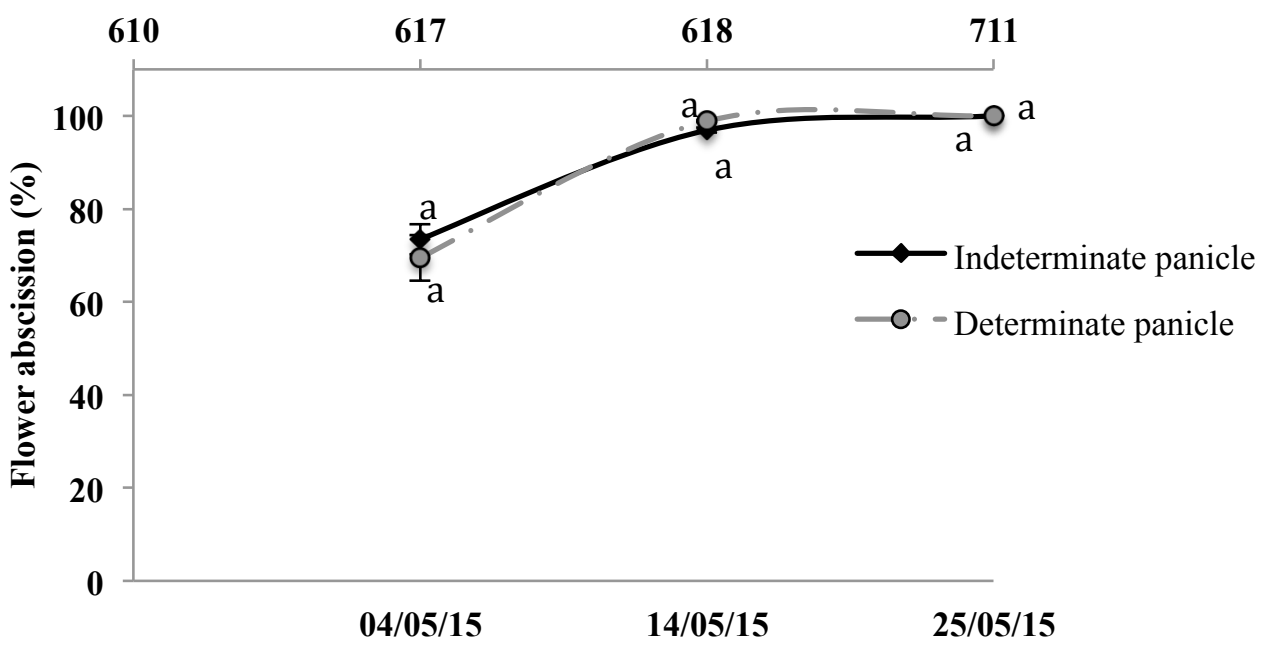

Figure 19. The time course of the percentage of flower abscission from indeterminate and determinate panicles in avocado trees cv. Hass cultivated in Llaurí (Valencia, Spain) (A) and Caronia Marina (Sicily, Italy) (B). Each point is the average of 10 thyrsi. Vertical bars indicate standard error. In some cases the SE was smaller than the size of the symbols. Different letters indicate significant differences $(P \leq 0.05)$. The upper axis represents the phenological stages according to the $\mathrm{BBCH}$ scale.

\subsection{The time course of fruit abscission. Number of fruits per panicle.}

\section{Influence of the flowers number}

The time course of fruit abscission in avocado cv. Hass, under the conditions of our experiment is presented in Figure 20.

In Llaurí, percentage curves of fruit abscission of indeterminate panicles and determinate panicles presented a similar behaviour. A week after fruit set (state 
$712 \mathrm{BBCH}$ ), abscission of the fruitlets was $92.2 \%$ in the indeterminate panicles and $84.8 \%$ in the determinate panicles (Figure $20 \mathrm{~A}$ ). The May 11 (state 713 $\mathrm{BBCH}$ ) abscission reached $98.7 \%$ in the first and $96.6 \%$ in the second. May 15 (state $715 \mathrm{BBCH}$ ) almost $100 \%$ of the structures drop in both types of panicles was reached.

In Caronia Marina (figure $20 \mathrm{~B}$ ), however, June 5 (state $712 \mathrm{BBCH}$ ) presented a $37.3 \%$ drop in indeterminate panicles and $49.1 \%$ in determinate panicles. June 26 (state $715 \mathrm{BBCH}$ ) abscission in indeterminate panicles reached $71.5 \%$ of fruitlets, while the determinate panicles $97.7 \%$.

But unlike that the abscission of flowers, newly fruit set was delayed in Caronia Marina. When the $43.2 \%$ of fruit, on average, had dropped in Caronia, Llaurí had already dropped the $88.3 \%$ (Figure 20).

According to the behaviours detected in Llaurí and Caronia Marina, fruitlets abscission in that species should not be controlled by nutritional competition between fruitlets and shoots, but probably by aspects of climate type or problems resulting from a lack of pollination.

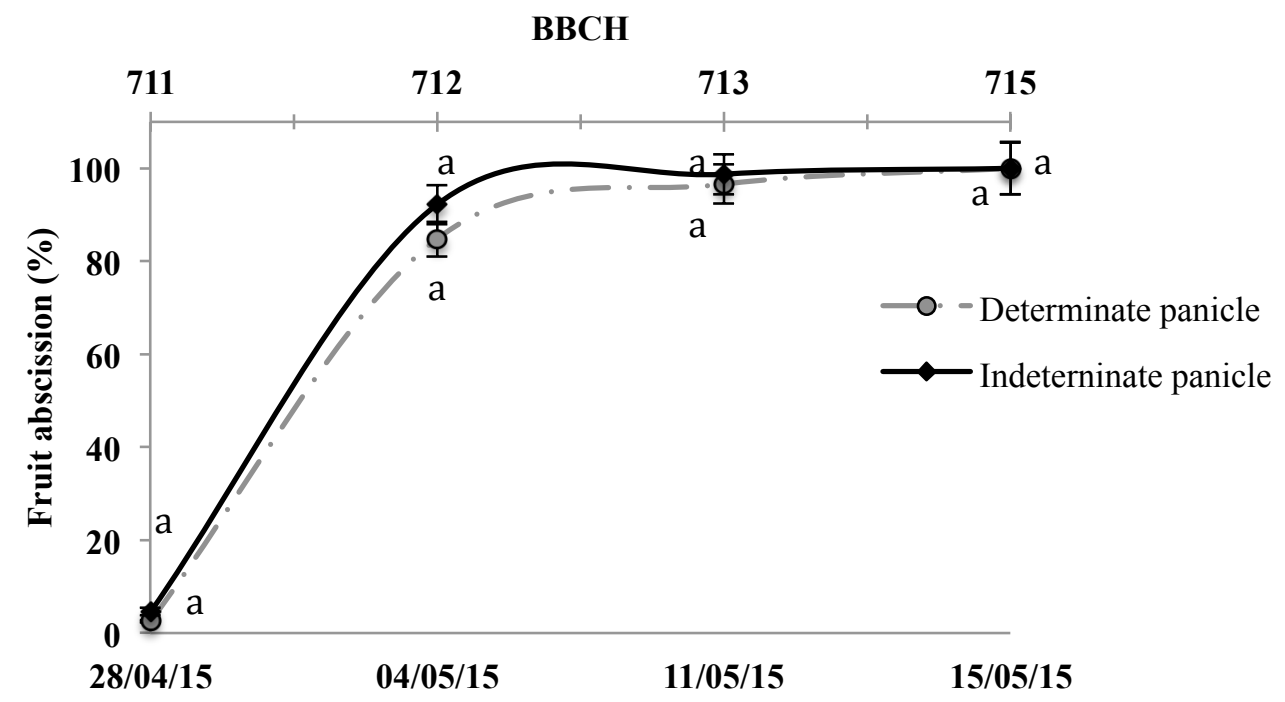




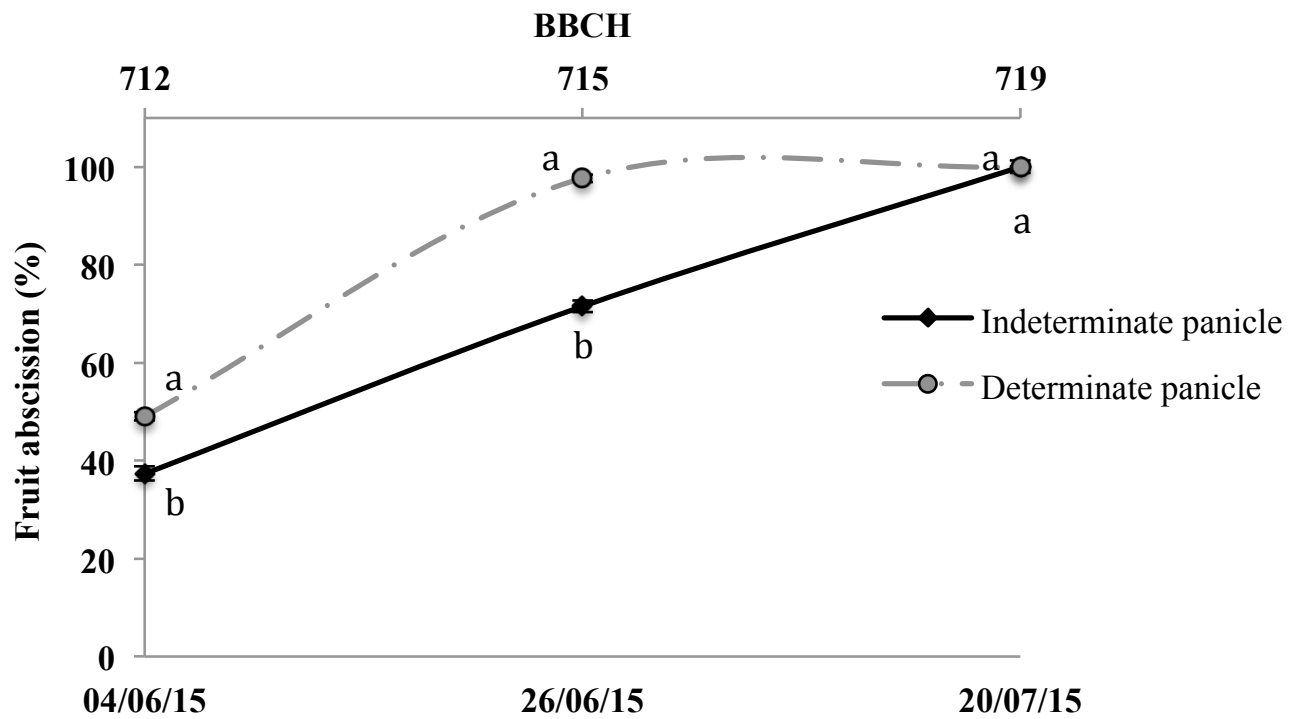

Figure 20: The time course of the percentage of fruit abscission from indeterminate and determinate panicles in avocado trees cv. Hass cultivated in Llaurí (Valencia, Spain) (A) and Caronia Marina (Sicily, Italy) (B). Each point is the average of 10 thyrsi. Vertical bars indicate standard error. In some cases the SE was smaller than the size of the symbols. Different letters indicate significant differences $(P \leq 0.05)$. The upper axis represents the phenological stages according to the $\mathrm{BBCH}$ scale.

As a result of the massive abscission of reproductive organs, the number of fruits per panicle that starts the growth is extremely low. Thus, 0.4 fruits per indeterminate panicle and 0.9 fruits per determinate panicle remained, on average, in Llaurí, and 0.4 and 2.8 fruits per panicle, respectively, in Caronia Marina (Figure 21).

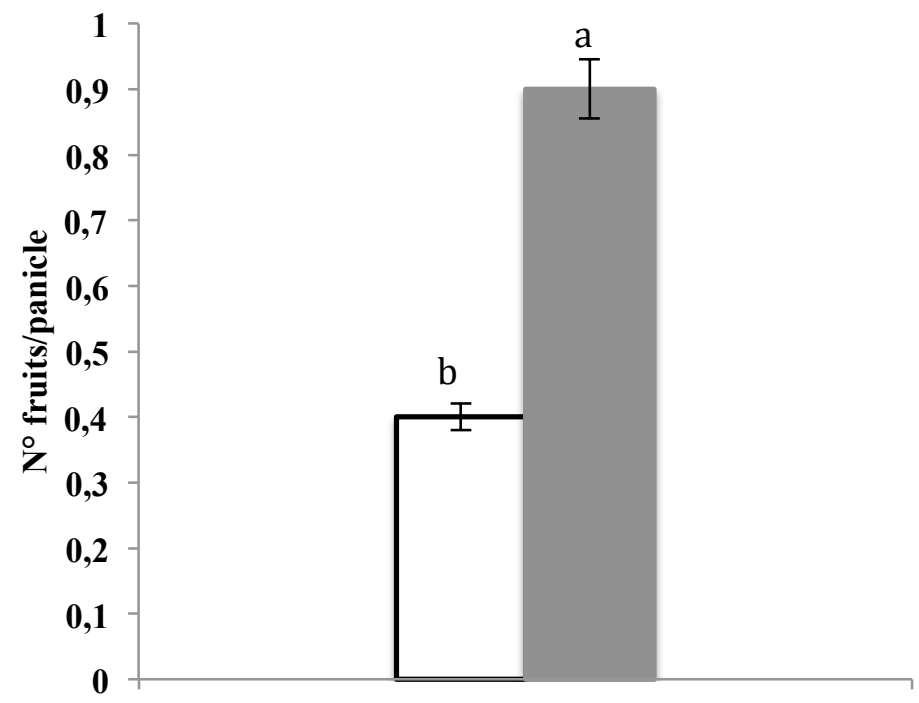

$13 / 07 / 15$

DIndeterninate panicle

Determinate panicle 


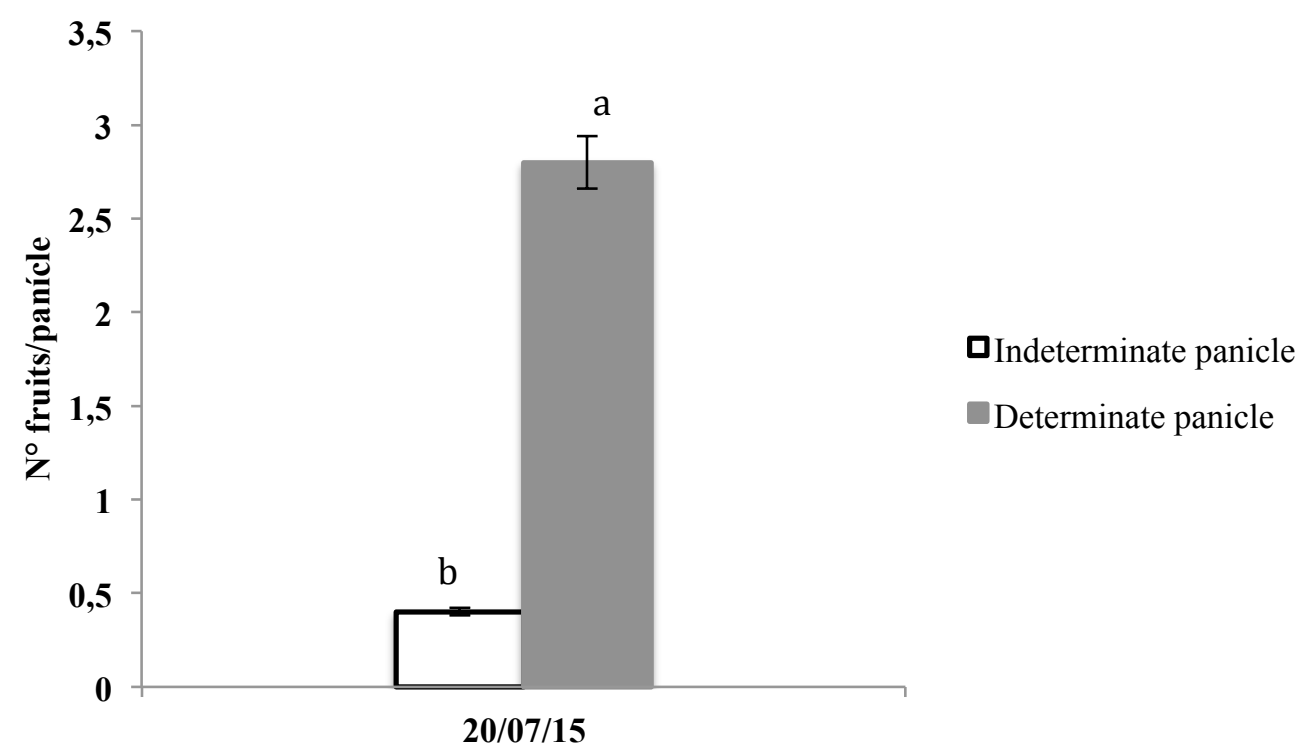

Figure 21: Number of fruits per panicle initiating development after the first abscission in avocado trees cv. Hass cultivated in Llaurí (Valencia, Spain) (A) and Caronia Marina (Sicily, Italy) (B). Each point is the average of 10 thyrsi. Vertical bars indicate standard error. Different letters indicate significant differences $(P \leq 0.05)$.

\subsection{Carbohydrate consumption}

During the abscission period of flowers and fruits in indeterminate and determinate panicles, we identified five soluble sugars: sucrose, fructose, glucose, glucose-6-P, and perseitol. Together, the content of these five sugars constitutes $98 \%$ of the total.

\subsubsection{Consumption during flowering}

The sucrose concentration of flowers drop followed a very similar pattern (with some quantitative difference) in the two parcels studied, and always higher values in the indeterminate panicles (Figure 22). In the state 617, in the parcel of Llaurí, the content of flowers drop was 28.5 and $18.9 \mathrm{mg} \mathrm{g}^{-1} \mathrm{DW}$ for indeterminate and determinate panicles, respectively, while Caronia Marina was 42.1 and $30.8 \mathrm{mg} \mathrm{g}^{-}$ ${ }^{1}$ DW. Over time it increased to 43.6 and $32.5 \mathrm{mg} \mathrm{g}^{-1} \mathrm{DW}$, respectively, in Llaurí (April 23), and 48.1 and $35.8 \mathrm{mg} \mathrm{g}^{-1} \mathrm{DW}$ in Caronia Marina (May 15), reaching at the time of fruit set (711 state $\mathrm{BBCH}$ scale) practically identical values for both types of panicles and in the two locations. In Llaurí (28 April) values were 54.9 and $53.6 \mathrm{mg} \mathrm{g}^{-1} \mathrm{DW}$ for flower drops from indeterminate and determinate panicles, respectively, and in Caronia Marina (May 25) 56.3 and $53.5 \mathrm{mg} \mathrm{g}^{-1} \mathrm{DW}$ (Figure 22). 

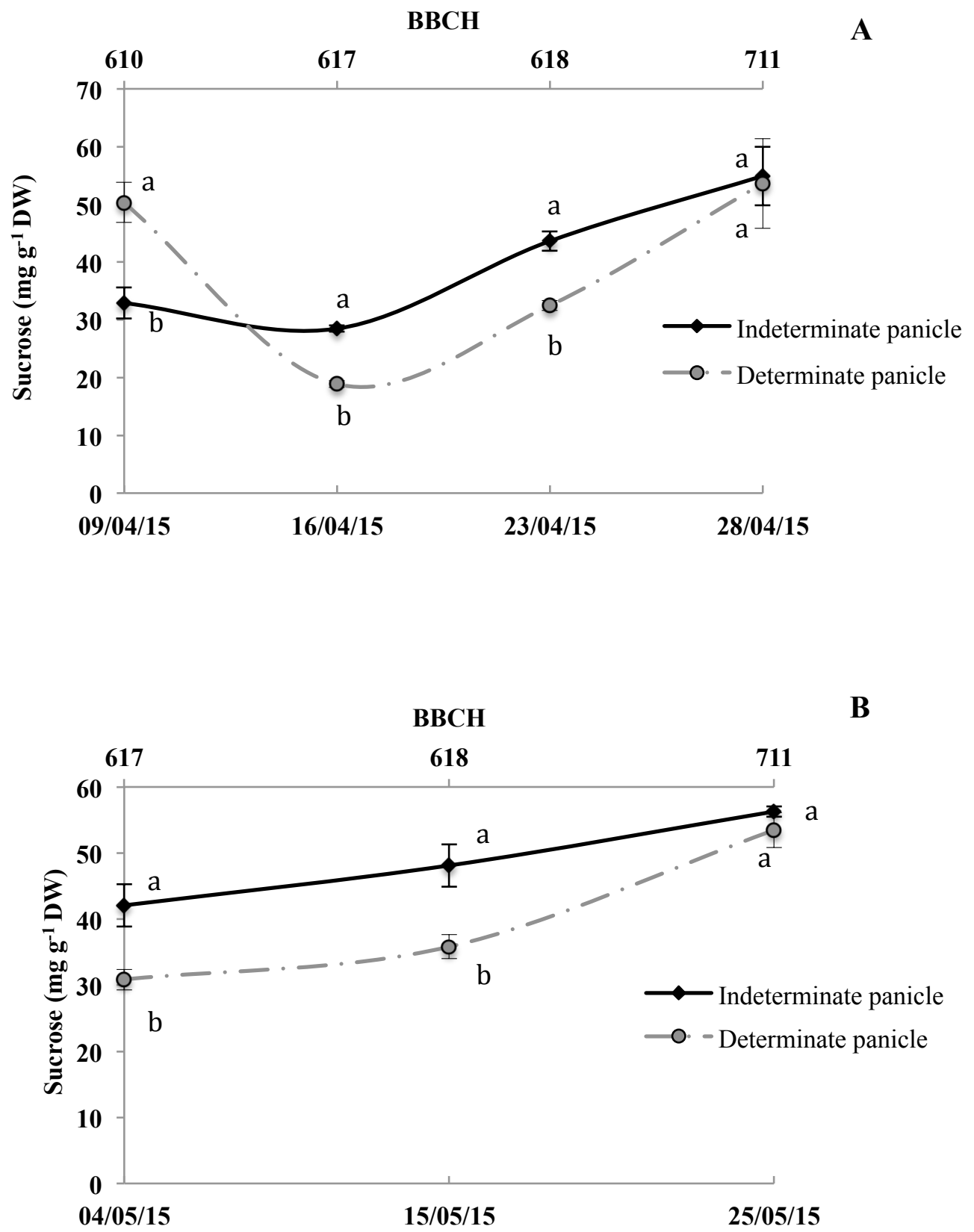

Figure 22: The time course of the sucrose concentration of flowers drop in Llaurí (Valencia, Spain) (A) y Caronia Marina (Sicilia Italy) (B) from indeterminate and determinate panicles in avocado trees cv. Hass. Each point is the average of 10 thyrsi. Vertical bars indicate standard error. Different letters indicate significant differences $(P \leq 0.05)$. The upper axis represents the phenological stages according to the $\mathrm{BBCH}$ scale.

In growing flowers, which did not drop, the time course of their sucrose concentration was also similar, although very noticeable quantitative differences. Thus, in the state 617 of the BBCH scale, the sucrose concentration in flower of indeterminate and determinate panicles was in Llaurí 57.5 and $49.1 \mathrm{mg} \mathrm{g}^{-1} \mathrm{DW}$, 
respectively, and in Caronia Marina 17.7 and $11.3 \mathrm{mg} \mathrm{g}^{-1} \mathrm{DW}$ (Figure 23). Seven days later, this concentration increased in Llaurí to values of 76.9 and 67.6 for flowers of indeterminate and determinate panicles, while in Caronia Marina 11 days later it was barely altered, with values of 18.0 and $10.8 \mathrm{mg} \mathrm{g}^{-1} \mathrm{DW}$ respectively. Finally, at the time of fruit set (state $711 \mathrm{BBCH}$ ) values decreased in both parcels, keeping markedly higher values in Llaurí, with 48.9 and $45.0 \mathrm{mg} \mathrm{g}^{-1}$ DW in flowers of indeterminate and determinate panicles respectively, that in Caronia Marina, with 6.8 and $5.1 \mathrm{mg} \mathrm{g}^{-1} \mathrm{DW}$, respectively (Figure 23).

BBCH

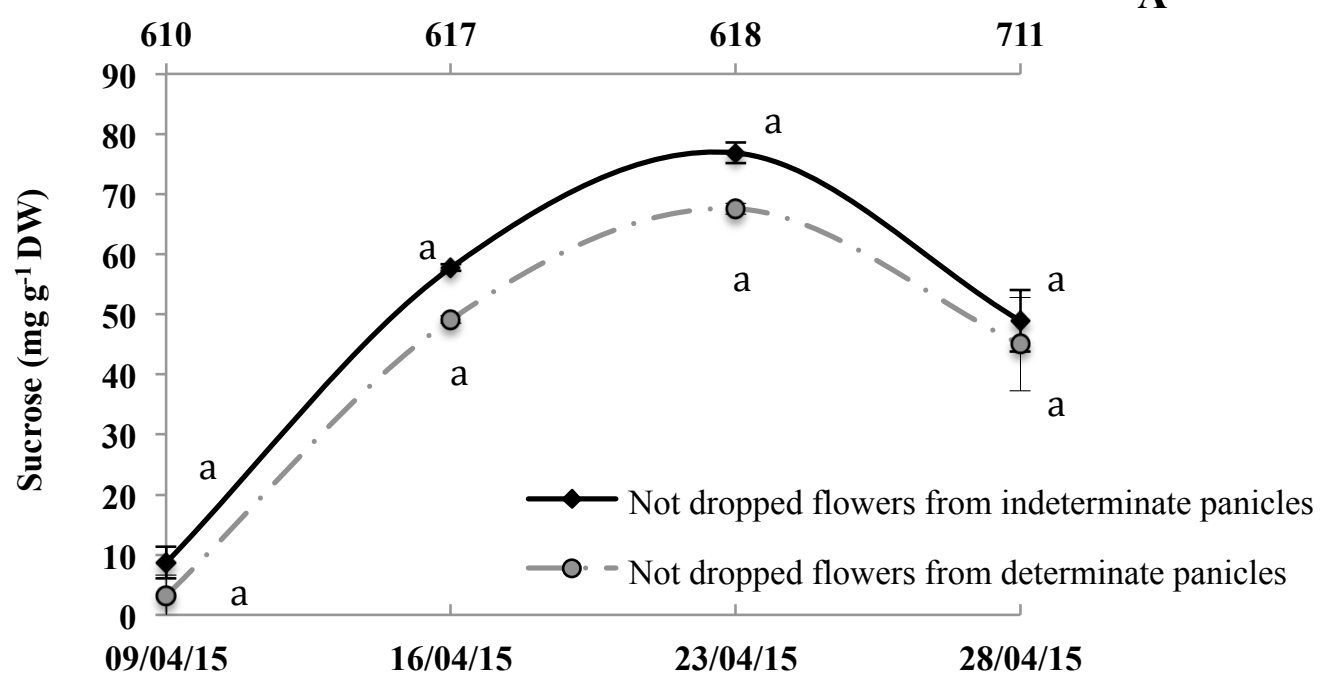

ВBCH

618

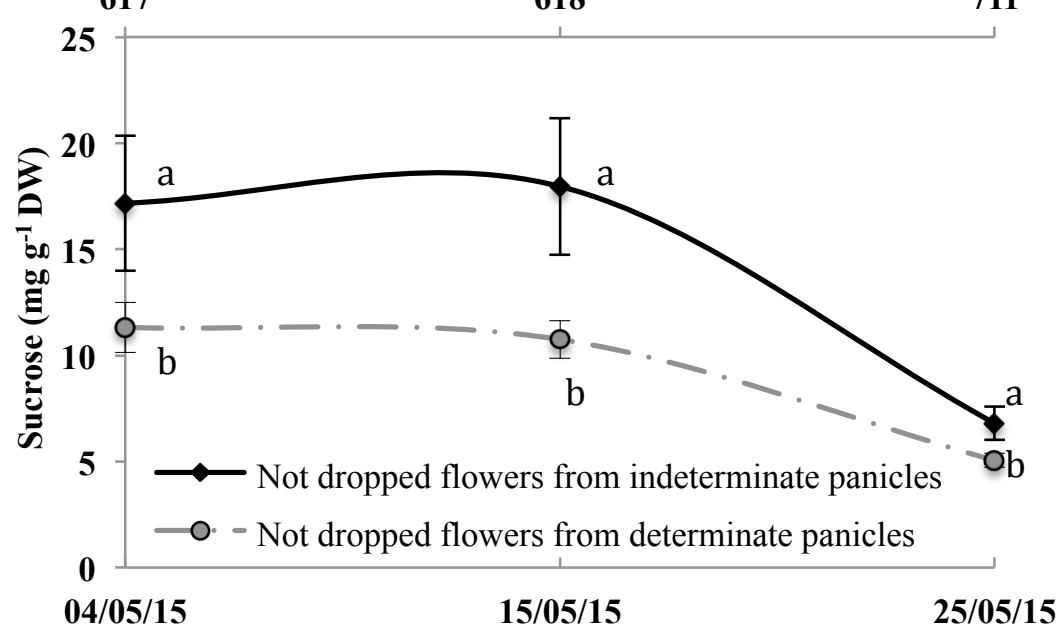

B

Figura 23: The time course of the sucrose concentration of not-dropped flowers in Llaurí (Valencia, Spain) (A) and Caronia Marina (Sicilia Italy) (B) from indeterminate and determinate panicles in avocado trees cv. Hass. Each point is the average of 10 thyrsi. Vertical bars indicate 
standard error. Different letters indicate significant differences $(P \leq 0.05)$. The upper axis represents the phenological stages according to the $\mathrm{BBCH}$ scale.

In view of similar behaviour in both parcels, the remaining carbohydrates were studied only in Llaurí, since it is where we also studied the fitohormonas content. In this parcel, the concentration of perseitol in the flowers of indeterminate panicles followed a similar evolution in dropped and not dropped flowers (Figure 24). Its concentration between 610 and 618 phenological stages of $\mathrm{BBCH}$ scale ranged from 14 to $16 \mathrm{mg} \mathrm{g}^{-1} \mathrm{DW}$, and decreased to values of $11 \mathrm{mg} \mathrm{g}^{-1} \mathrm{DW}$ in the state 711 . In flowers of determinate panicles the time course of the concentration was also similar between them, but with statistically significant differences from the flowers of indeterminate panicles. In this case, the concentration slightly increased to phenological state 618 , reaching values of 16.7 and $13.5 \mathrm{mg} \mathrm{g}^{-1} \mathrm{DW}$ in dropped and not dropped flowers, respectively, to decrease in both cases, a week later, down to 10.2 and $6.3 \mathrm{mg} \mathrm{g}^{-1} \mathrm{DW}$, respectively (Figure 24). Also for this carbohydrate, the concentration was always higher in the flower of indeterminate panicles (Figure 24).

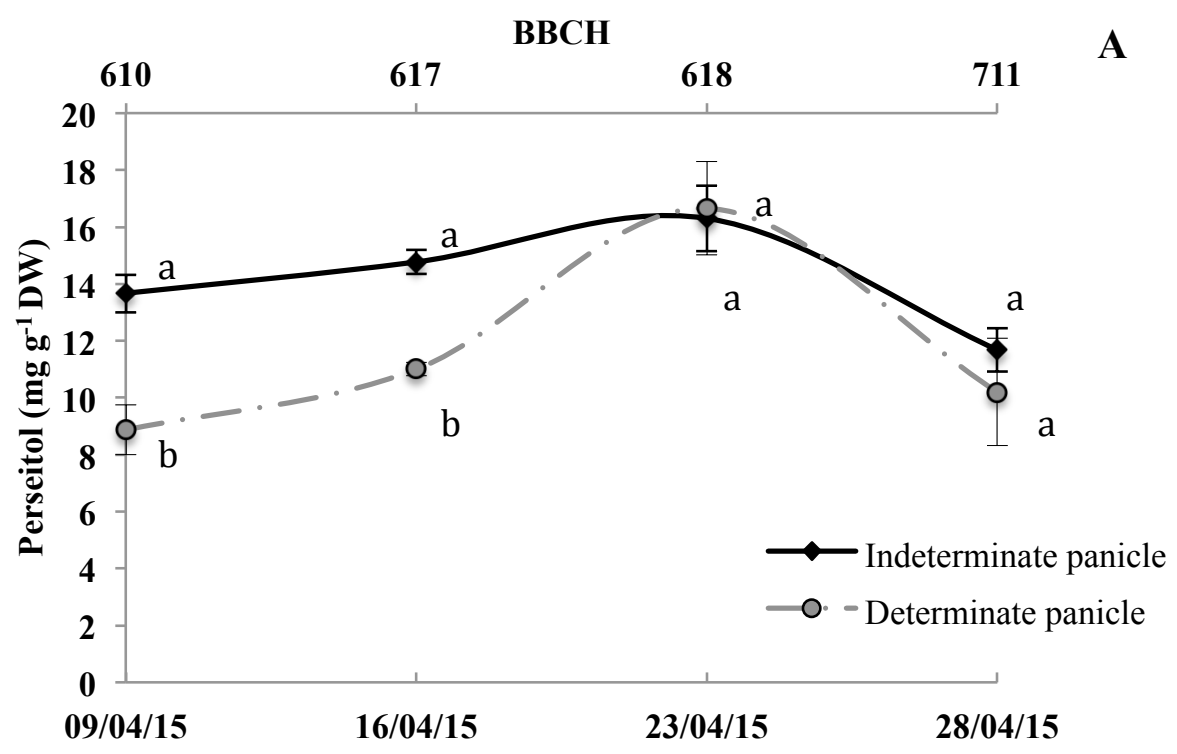




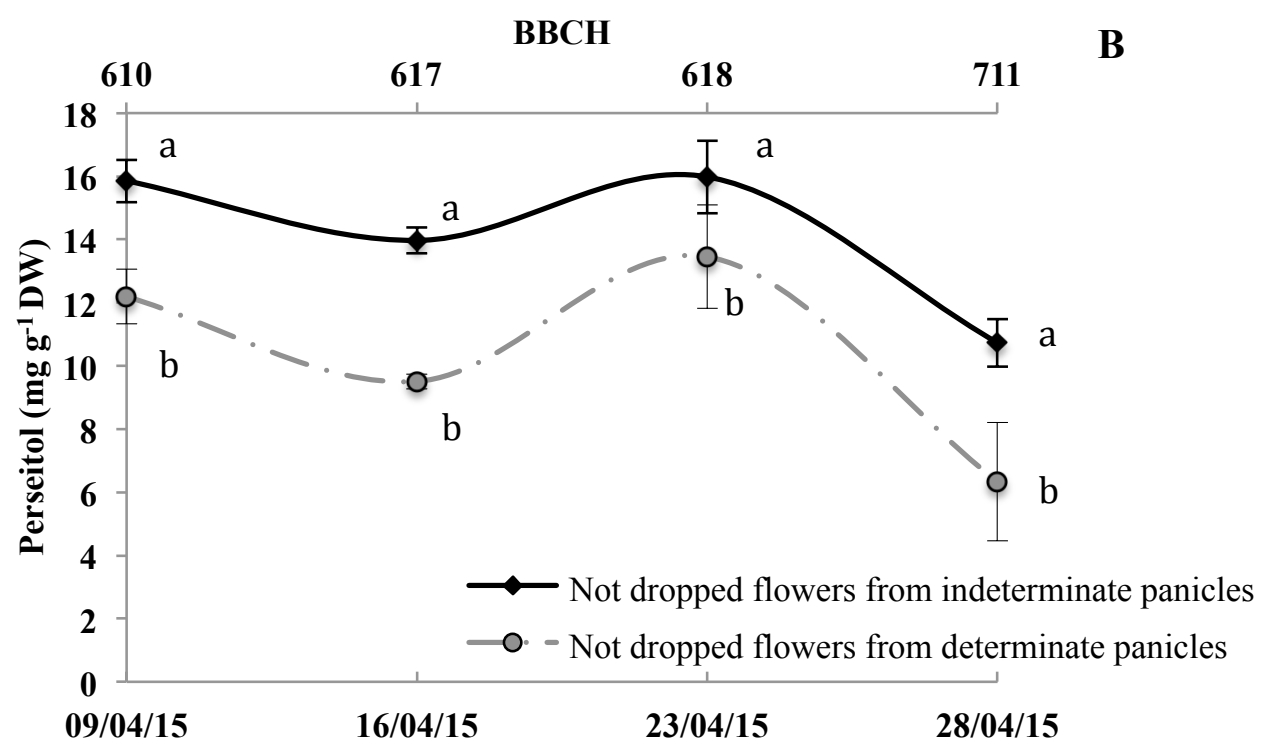

Figure 24: The time course of the perseitol concentration in dropped (A) and not-dropped (B) flowers from indeterminate and determinate panicles in avocado trees cv. Hass cultivated in Llaurí. Each point is the average of 10 thyrsi. Vertical bars indicate standard error. Different letters indicate significant differences $(P \leq 0.05)$. The upper axis represents the phenological stages according to the $\mathrm{BBCH}$ scale.

The time course of glucose and fructose is similar for both flowers of indeterminate and determinate panicles or for dropped and not dropped flowers, although there are quantitative differences (Figures 25 and 26). Their concentration slightly increases between the phenological stages 610 and 617 of the $\mathrm{BBCH}$ scale for flowers dropped from indeterminate panicles and between 610 and 618 for the flowers dropped from determinate panicles from which decreases to fruit set (state $711 \mathrm{BBCH})$. For glucose, the concentration is 28-39 $\mathrm{mg} \mathrm{g}^{-1} \mathrm{DW}$ for the flowers dropped from indeterminate panicles, and 20-37 $\mathrm{mg} \mathrm{g}^{-1}$ DW for the flowers dropped from determinate panicles (Figure $25 \mathrm{~A}$ ). For fructose concentrations are in the range $35-50 \mathrm{mg} \mathrm{g}^{-1} \mathrm{DW}$ and $32-45 \mathrm{mg} \mathrm{g}^{-1} \mathrm{DW}$, respectively (Figure $26 \mathrm{~A}$ ).

For not dropped flowers, glucose concentration in indeterminate and determinate panicles increased 2.5 and 6 times, respectively, from state $610 \mathrm{BBCH}$ (19.4 and $8.3 \mathrm{mg} \mathrm{g}^{-1} \mathrm{DW}$, respectively) to the state $618 \mathrm{BBCH}$ (51.7 and $49.9 \mathrm{mg} \mathrm{g}^{-1} \mathrm{DW}$, respectively), falling below $13 \%$ and $27 \%$ (44.9 and $36.3 \mathrm{mg} \mathrm{g}^{-1} \mathrm{DW}$ ), respectively (Figure 25B). For fructose, it increased between states 610 and 618 of the $\mathrm{BBCH}$ scale and was 2.3 and 3.1 times for flowers of indeterminate and determinate panicles respectively (20.7 to $48.5 \mathrm{mg} \mathrm{g}^{-1} \mathrm{DW}$, and 15.6 to $48.1 \mathrm{mg} \mathrm{g}^{-}$ 
${ }^{1} \mathrm{DW}$, respectively), and the descent to the state 711 was just non-existent in the first and $17 \%$ in the second (Figure $26 \mathrm{~B}$ ).
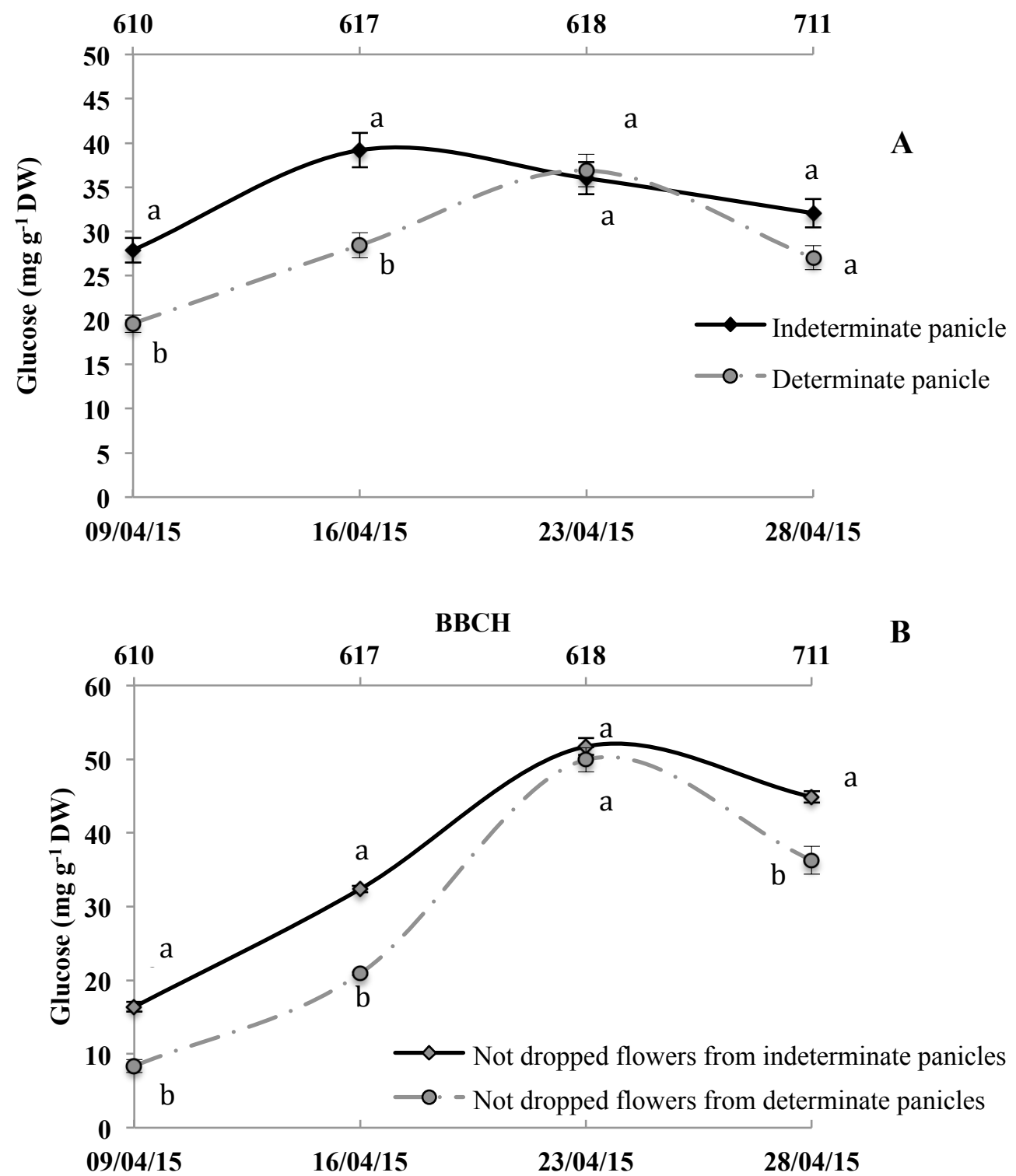

Figure 25: The time course of the glucose concentration in dropped (A) and not-dropped (B) flowers from indeterminate and determinate panicles in avocado trees cv. Hass cultivated in Llaurí. Each point is the average of 10 thyrsi. Vertical bars indicate standard error. Different letters indicate significant differences $(P \leq 0.05)$. The upper axis represents the phenological stages according to the $\mathrm{BBCH}$ scale. 

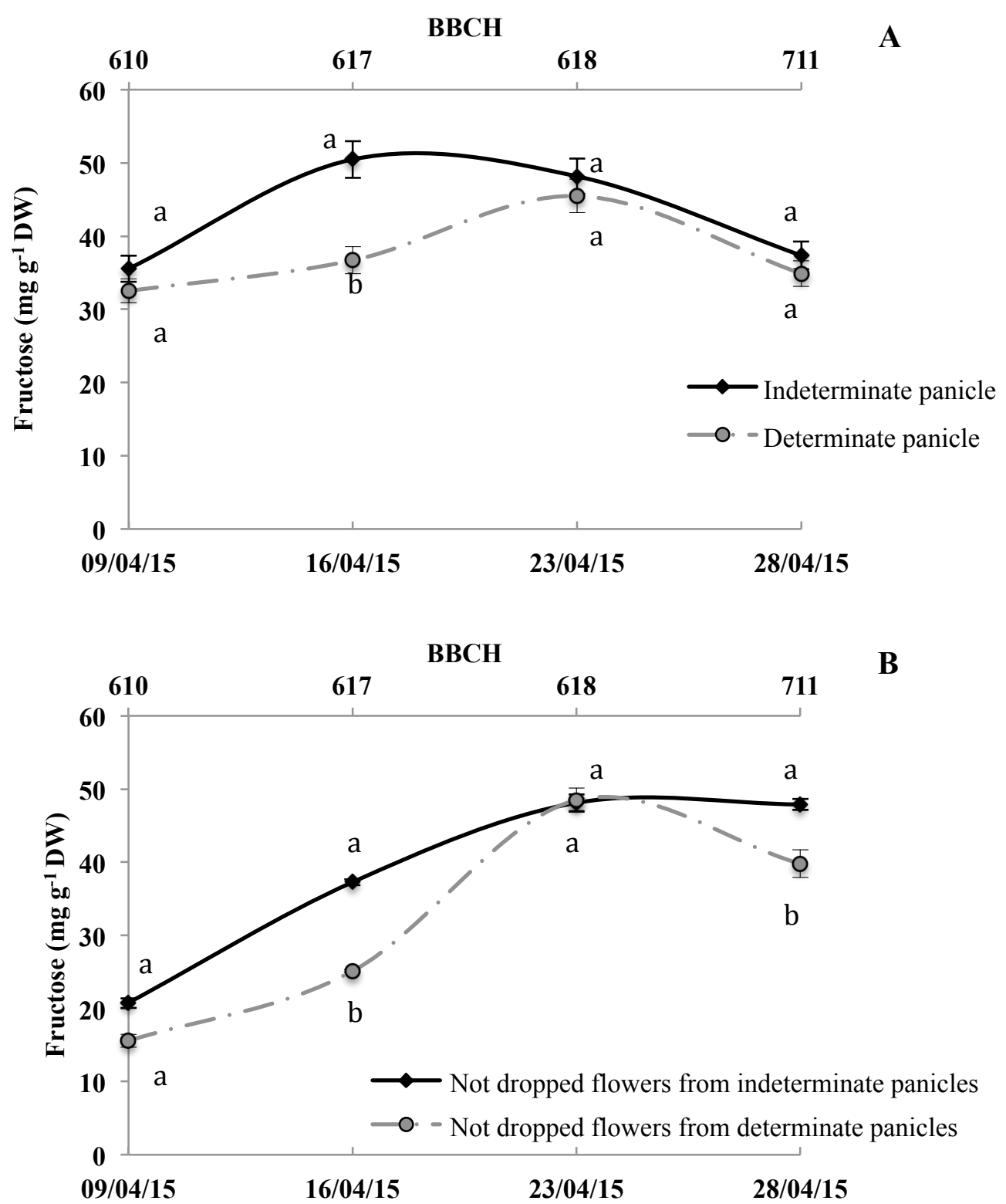

Figure 26: The time course of the fructose concentration in dropped (A) and not-dropped (B) flowers from indeterminate and determinate panicles in avocado trees cv. Hass cultivated in Llaurí. Each point is the average of 10 thyrsi. Vertical bars indicate standard error. Different letters indicate significant differences $(P \leq 0.05)$. The upper axis represents the phenological stages according to the $\mathrm{BBCH}$ scale.

\subsubsection{Consumption during the initial development of fruit}

The sucrose concentration of the fruit during the initial phase of development (phenological state 711 to 715 of $\mathrm{BBCH}$ scale) followed a similar evolution in indeterminate and determinate panicles and independence that had dropped or not dropped (Figure 27). Thus among the states 711 to $715 \mathrm{BBCH}$ kinetics was similar for all the fruits, although with some quantitative differences. Between 711 and $712 \mathrm{BBCH}$ states concentrations were barely disturbed, oscillating 
between 7.2 and $8.5 \mathrm{mg} \mathrm{g}^{-1} \mathrm{DW}$ and 13.1 and $3.2 \mathrm{mg} \mathrm{g}^{-1} \mathrm{DW}$ in the dropped and not dropped fruits, respectively. These concentrations decreased over time until reaching minimum values in the states $713-715 \mathrm{BBCH}(4.8$ and 2.1 for the dropped fruits in indeterminate and determinate panicles, respectively, and 2.1 and 3.4 for the not dropped fruits) and subsequently the concentrations increased very little in the dropped fruits. Logically, and dramatically in not dropped fruits reached values of 18.9 and $17.3 \mathrm{mg} \mathrm{g}^{-1} \mathrm{DW}$ in the state $716 \mathrm{BBCH}$ in indeterminate and determinate panicles, respectively, and 26.1 and $23.7 \mathrm{mg} \mathrm{g}^{-1}$ DW in $717 \mathrm{BBCH}$, but in any case the statistical significance was reached (Figure 27). The dropped fruits in $715 \mathrm{BBCH}$ reached statistically different values of $4.8 \mathrm{y}$ $2.1 \mathrm{mg} \mathrm{g}^{-1} \mathrm{DW}$, depending on their location in indeterminate and determinate panicles (Figure 27). Beyond this state, no fruit drop was recorded, the physiological fruit drop ended in the state 715 of the $\mathrm{BBCH}$ scale.

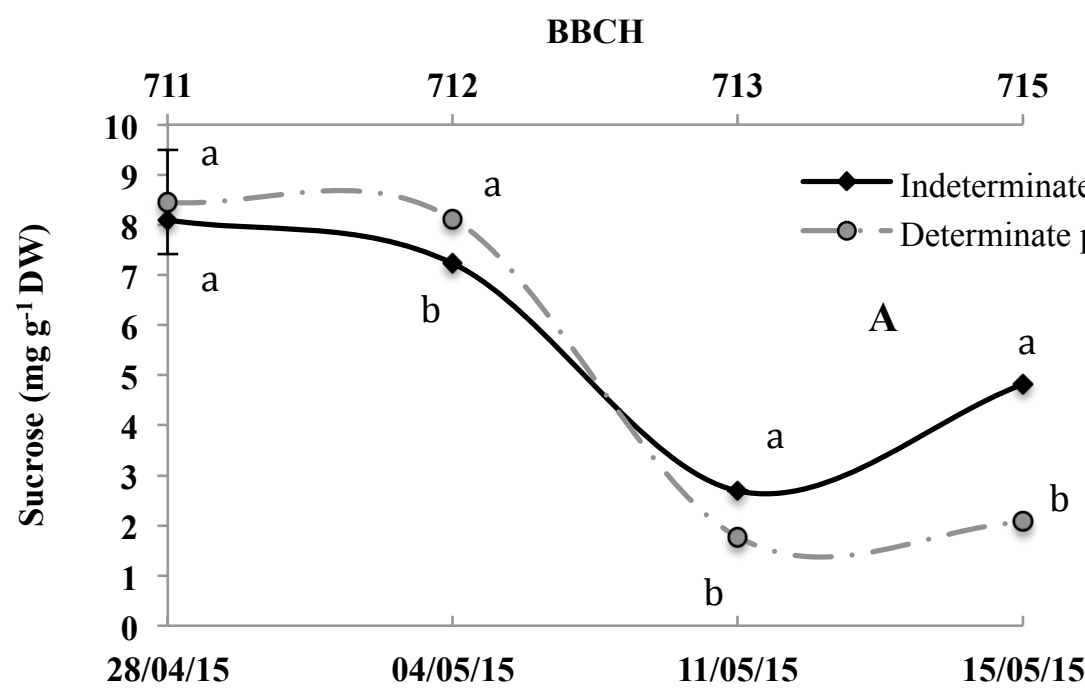




\section{BBCH}

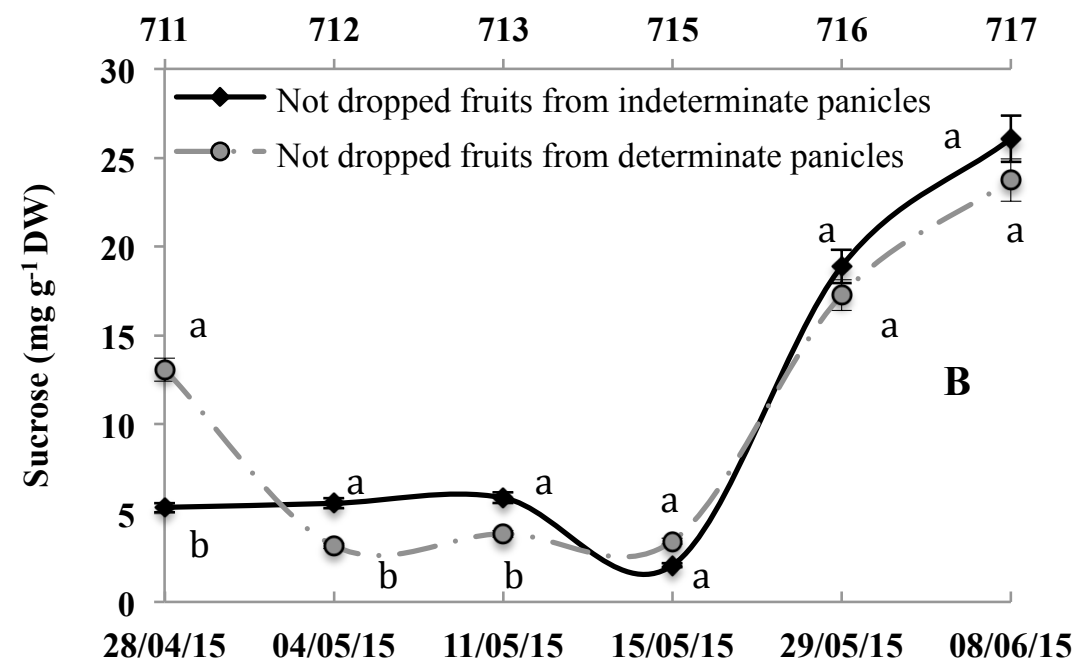

Figure 27: The time course of the sucrose concentration in dropped (A) and not-dropped (B) fruits from indeterminate and determinate panicles in avocado trees cv. Hass cultivated in Llaurí. Each point is the average of 10 thyrsi. Vertical bars indicate standard error. Different letters indicate significant differences $(P \leq 0.05)$. The upper axis represents the phenological stages according to the BBCH scale.

In fruits drop, the concentration of perseitol barely was altered between phenological stages 711 and $715 \mathrm{BBCH}$ scale, whether they were located in indeterminate or determinate panicles, oscillating between 6 and $8 \mathrm{mg} \mathrm{g}^{-1} \mathrm{DW}$ (Figure 28).

A

\section{BBCH}

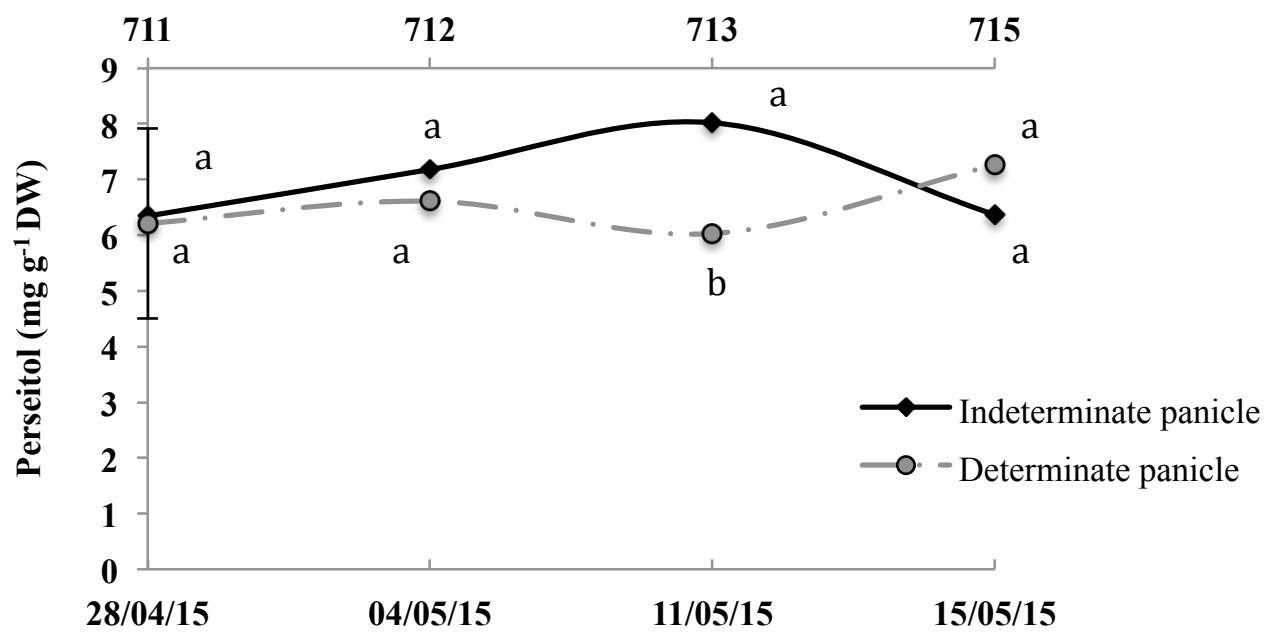




\section{BBCH}

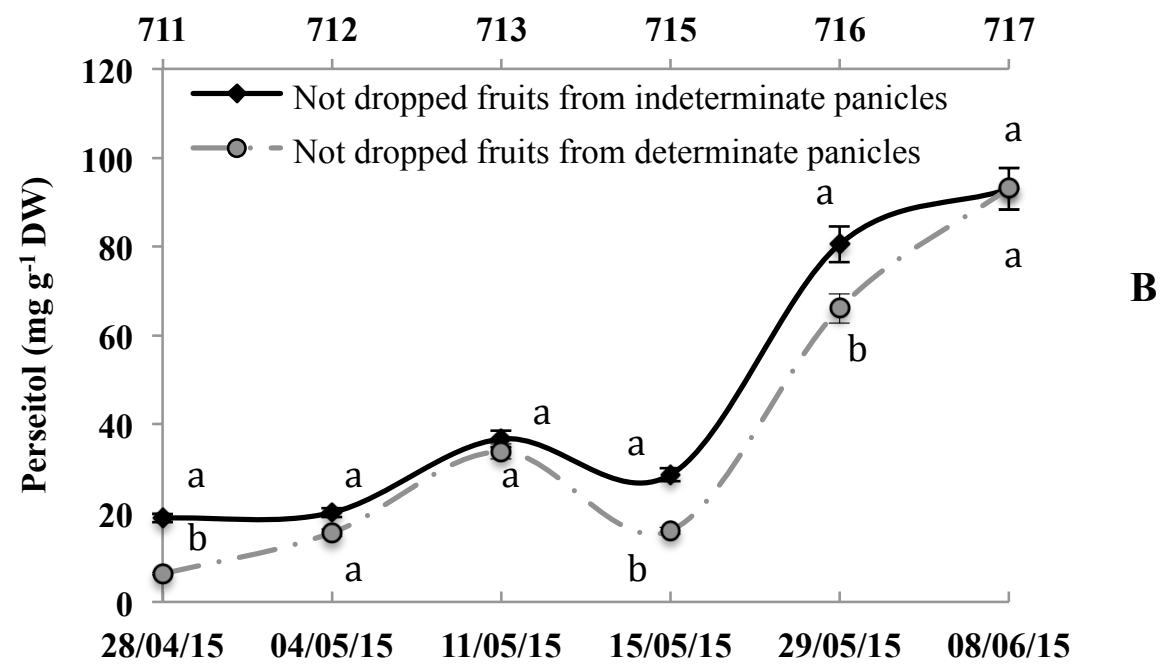

Figure 28: The time course of the perseitol concentration in dropped (A) and not-dropped (B) fruits from indeterminate and determinate panicles in avocado trees cv. Hass cultivated in Llaurí. Each point is the average of 10 thyrsi. Vertical bars indicate standard error. Different letters indicate significant differences $(P \leq 0.05)$. The upper axis represents the phenological stages according to the $\mathrm{BBCH}$ scale.

However, in the not dropped fruits, although similar developments between 711 and $713 \mathrm{BBCH}$ states, i.e., oscillating in time, but without great temporal changes (their concentration varied between 6.3 and $33.8 \mathrm{mg} \mathrm{g}^{-1} \mathrm{DW}$ ), after the fruit drop (state $715 \mathrm{BBCH}$ ) perseitol concentration increased by 3.2 and 5.8 times in fruits of indeterminate and determinate panicles acquiring the same value in both cases $93.2 \mathrm{mg} \mathrm{g}^{-1} \mathrm{DW}$ (Figure 28).

As in the case of flowers, the evolution of the concentration of glucose and fructose was very similar for both types of fruits, that is, from indeterminate and determinate panicles. And, as in those, the differences were marked between the values of the dropped and not dropped fruits (Figures 29 and 30). In fruits drop, and regardless of the panicle type, glucose concentration between phenological stages 711 and $715 \mathrm{BBCH}$ ranged between 18.9 and $22.7 \mathrm{mg} \mathrm{g}^{-1} \mathrm{DW}$ (Figure 29), and fructose between 16.2 and $24.1 \mathrm{mg} \mathrm{g}^{-1} \mathrm{DW}$ (Figure 30). At the end of the physiological fruit drop, both monosaccharides concentration was significantly higher in the fruit drop of indeterminate panicles.

The concentration of glucose and fructose in not dropped fruits was oscillating between phenological stages 711 and $717 \mathrm{BBCH}$, with three peaks for glucose in 
the states 711, 713 and 716, and two for fructose in the states 713 and 717 (Figures 29 and 30). The glucose concentration in the fruit from $715 \mathrm{BBCH}$, that is, the end of physiological fruit drop, did not present significant differences between indeterminate and determinate panicles (Figure 29). While the fructose was significantly higher in the fruits from determinate panicles, increasing the gap over time to be highest in the state $717 \mathrm{BBCH}, 90.2 \mathrm{mg} \mathrm{g}^{-1} \mathrm{DW}$ versus $67.7 \mathrm{mg} \mathrm{g}^{-}$ ${ }^{1} \mathrm{DW}$ of fruits from indeterminate panicles.

A
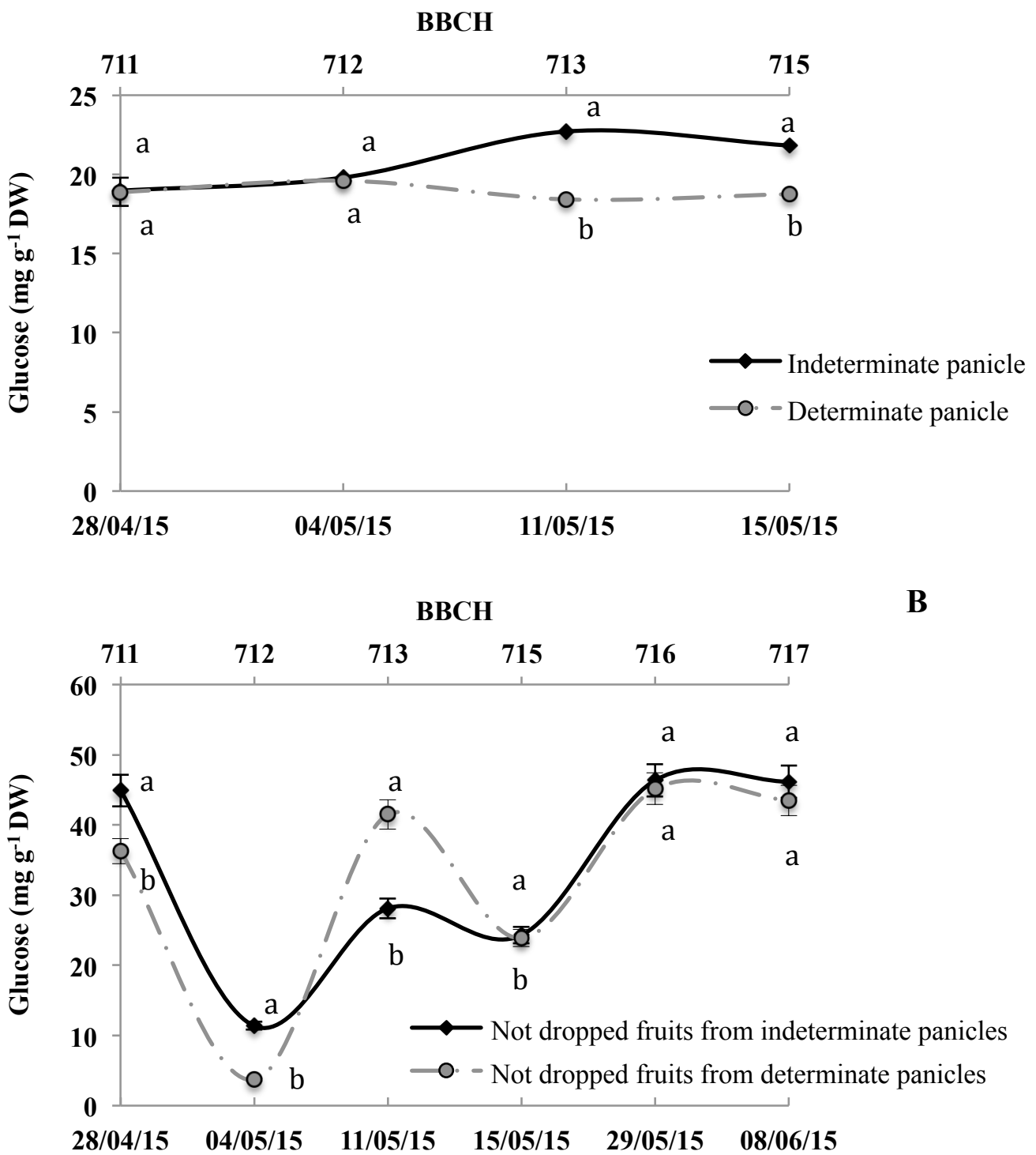

Figure 29: The time course of the glucose concentration in dropped (A) and not-dropped (B) fruits from indeterminate and determinate panicles in avocado trees cv. Hass cultivated in Llaurí. Each point is the average of 10 thyrsi. Vertical bars indicate standard error. Different letters indicate significant differences $(P \leq 0.05)$. The upper axis represents the phenological stages according to the $\mathrm{BBCH}$ scale. 

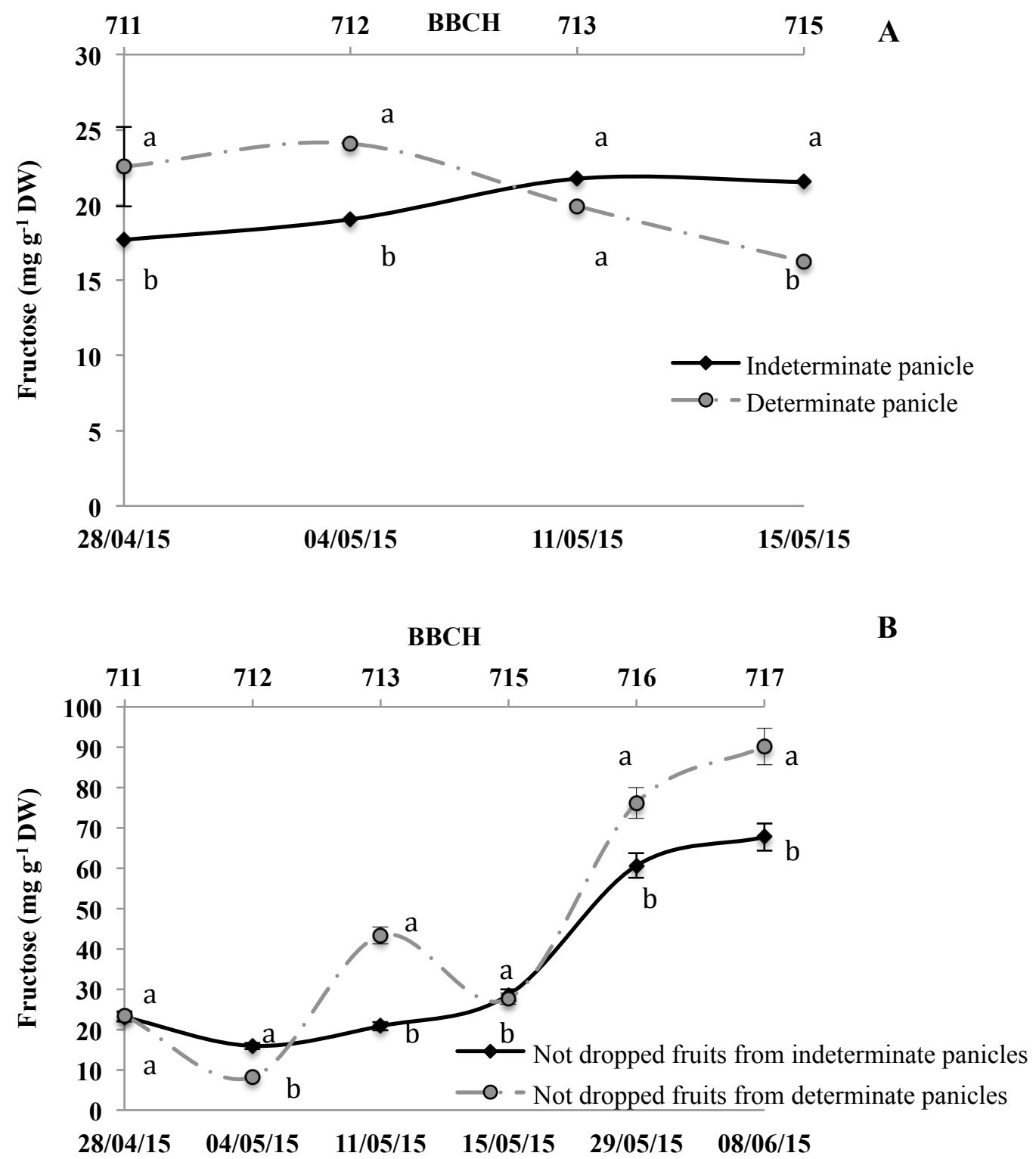

Figure 30: The time course of the fructose concentration in dropped (A) and not-dropped fruits (B) from indeterminate and determinate panicles in avocado trees cv. Hass cultivated in Llaurí. Each point is the average of 10 thyrsi. Vertical bars indicate standard error. Different letters indicate significant differences $(P \leq 0.05)$. The upper axis represents the phenological stages according to the $\mathrm{BBCH}$ scale.

\subsection{Endogenous hormonal control}

\subsubsection{During flowering}

Regarding gibberellins of non-hydroxylation route in flowers drop from indeterminate and determinate panicles, $\mathrm{GA}_{9}$ content decreased by about $90 \%$, during flowering and until fruit set, without significant detected differences between the two types of inflorescences (Figure 31). 


\section{BBCH}

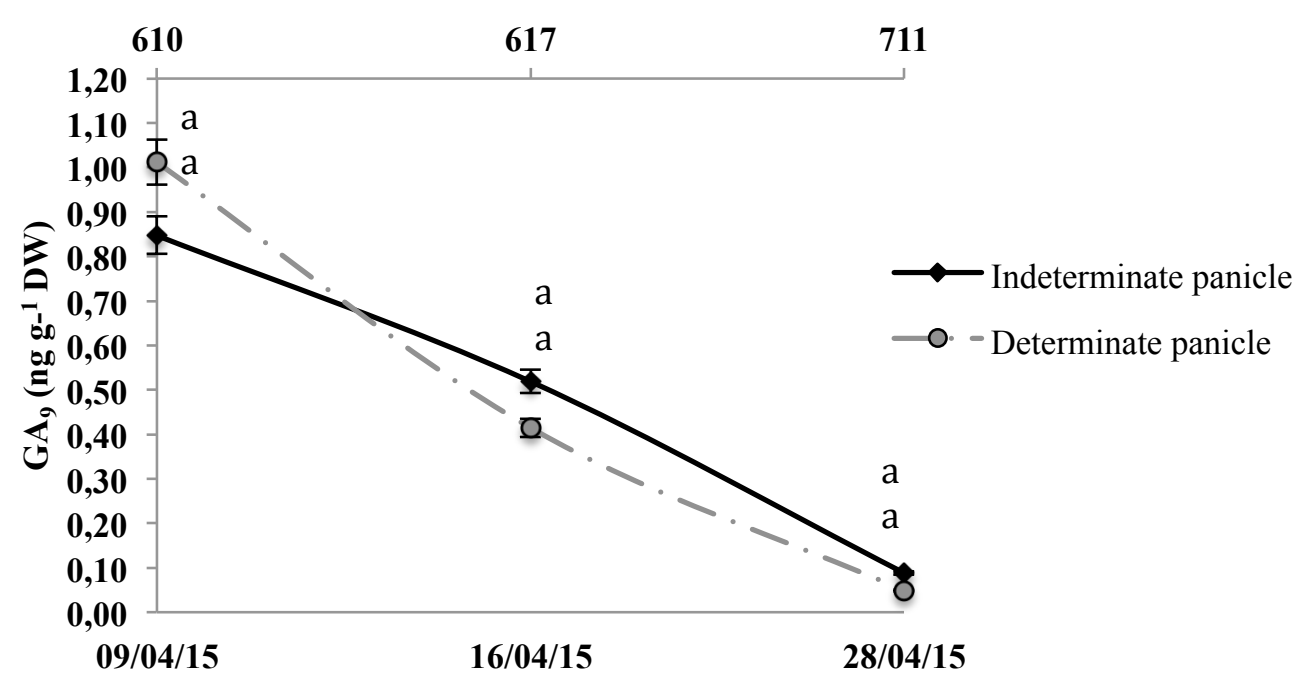

Figure 31: The time course of $\mathrm{GA}_{9}$ concentration in flowers drop from indeterminate and determinate panicles in avocado trees cv. Hass. Each point is the average of three replications. Vertical bars indicate standard error. Different letters indicate significant differences $(P \leq 0.05)$. The upper axis represents the phenological stages according to the $\mathrm{BBCH}$ scale.

The concentration of its catabolite $\left(\mathrm{GA}_{51}\right)$ also decreased over time, but in lower magnitude $(25-30 \%)$, especially for flowers from determinate panicles, while for flowers from indeterminate panicles its concentration remained virtually constant (Figure 32). However, the $\mathrm{GA}_{4}$ gibberellin, active in tissues, was not detected.

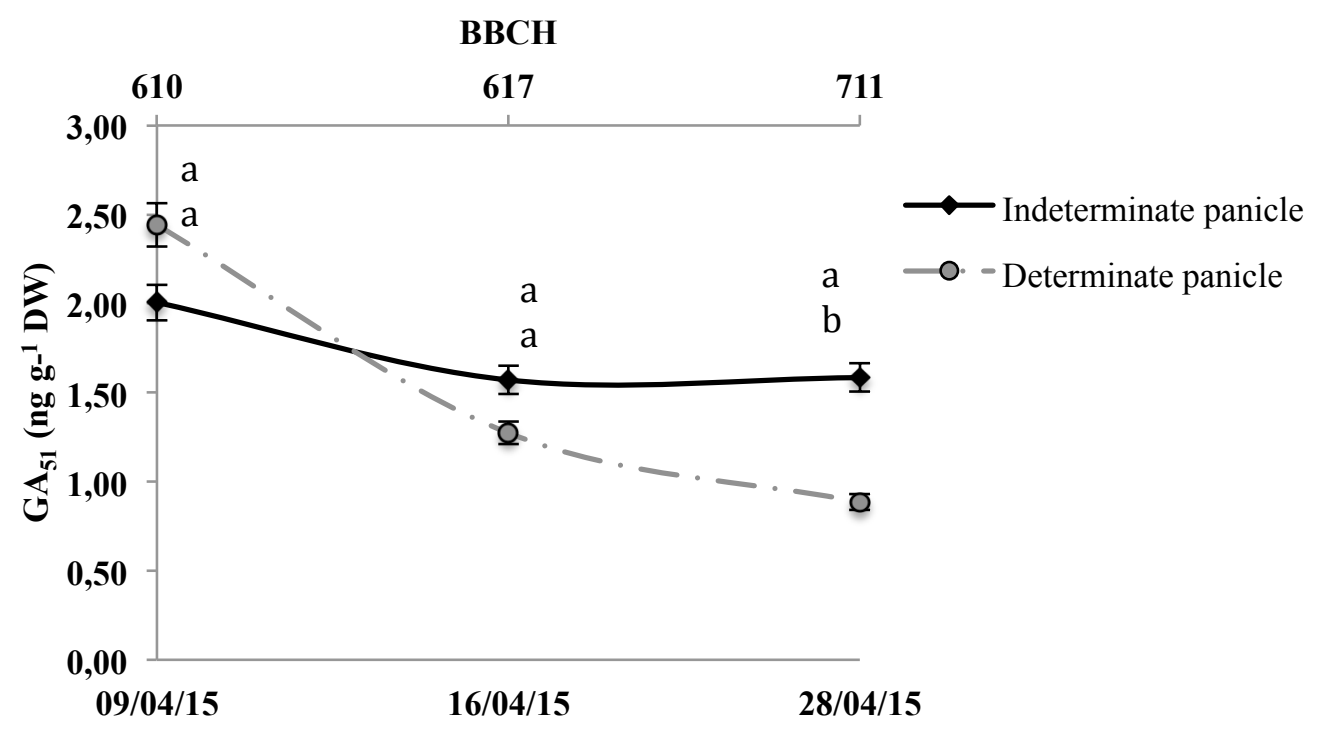

Figure 32: The time course of $\mathrm{GA}_{51}$ concentration in flowers drop from indeterminate and determinate panicles in avocado trees cv. Hass. Each point is the average of three replications. Vertical bars indicate standard error. Different letters indicate significant differences $(P \leq 0.05)$. The upper axis represents the phenological stages according to the $\mathrm{BBCH}$ scale. 
Regarding gibberellins of 13-hydroxylation route, while the concentration of $\mathrm{GA}_{19}$ increased with time (Figure 33) the concentration of $\mathrm{GA}_{20}$ decreased (Figure 34) and this evolution could be explained by the increased concentration of catabolite $\mathrm{GA}_{29}$ of the latter (Figure 35). But in any case, the concentration of these three gibberellin is so low (mostly below $0.8 \mathrm{ng} \mathrm{g}^{-1} \mathrm{DW}$ ) that it would be erroneous to confer importance on it. Moreover, the $\mathrm{GA}_{1}$ gibberellin, active in plant tissues, was not detected, while its catabolite, the $\mathrm{GA}_{8}$, increased with time and was the one with the highest concentration (between 2 and $5 \mathrm{ng} \mathrm{g}^{-1} \mathrm{DW}$ ) (Figure 36). The trend was similar in all flower drops from indeterminate and determinate panicles. These results suggest that the 13- $\beta$ hidroxilation route of gibberellins in this species could be merely catabolic.

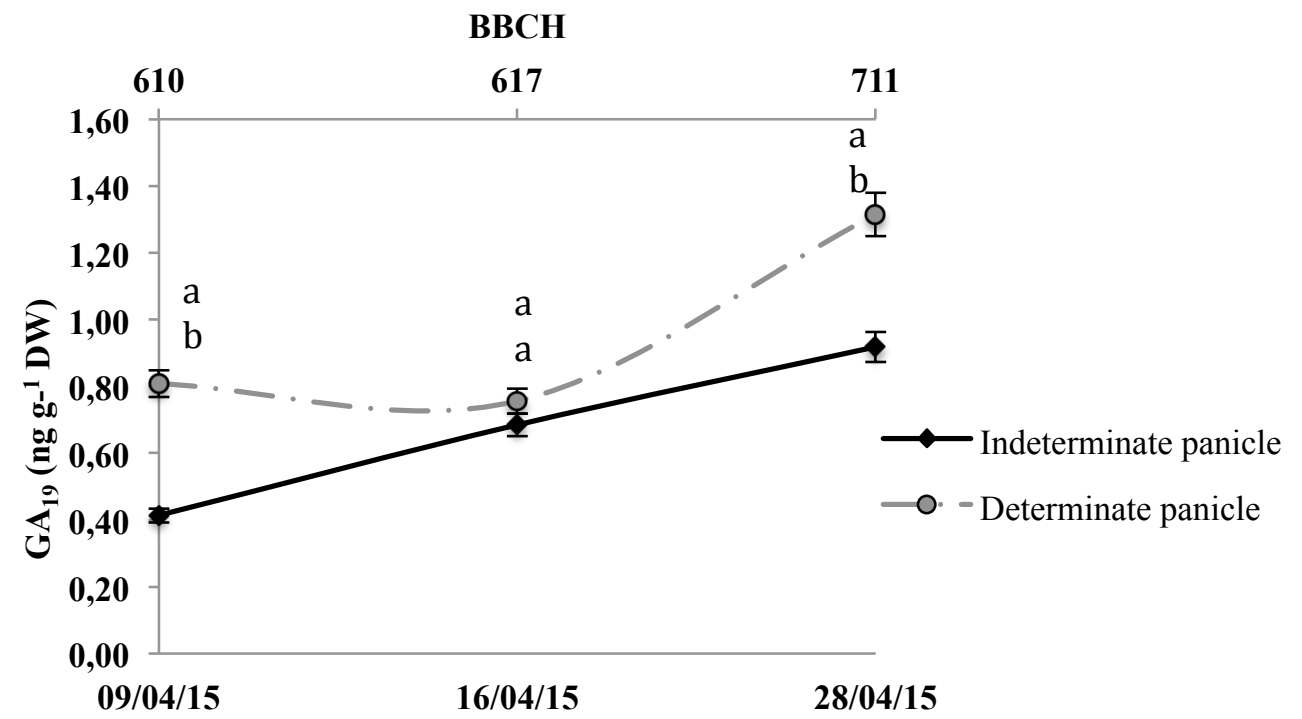

Figure 33: The time course of $\mathrm{GA}_{19}$ concentration in flower drop from indeterminate and determinate panicles in avocado trees cv. Hass. Each point is the average of three replications. Vertical bars indicate standard error. Different letters indicate significant differences $(P \leq 0.05)$. The upper axis represents the phenological stages according to the $\mathrm{BBCH}$ scale. 


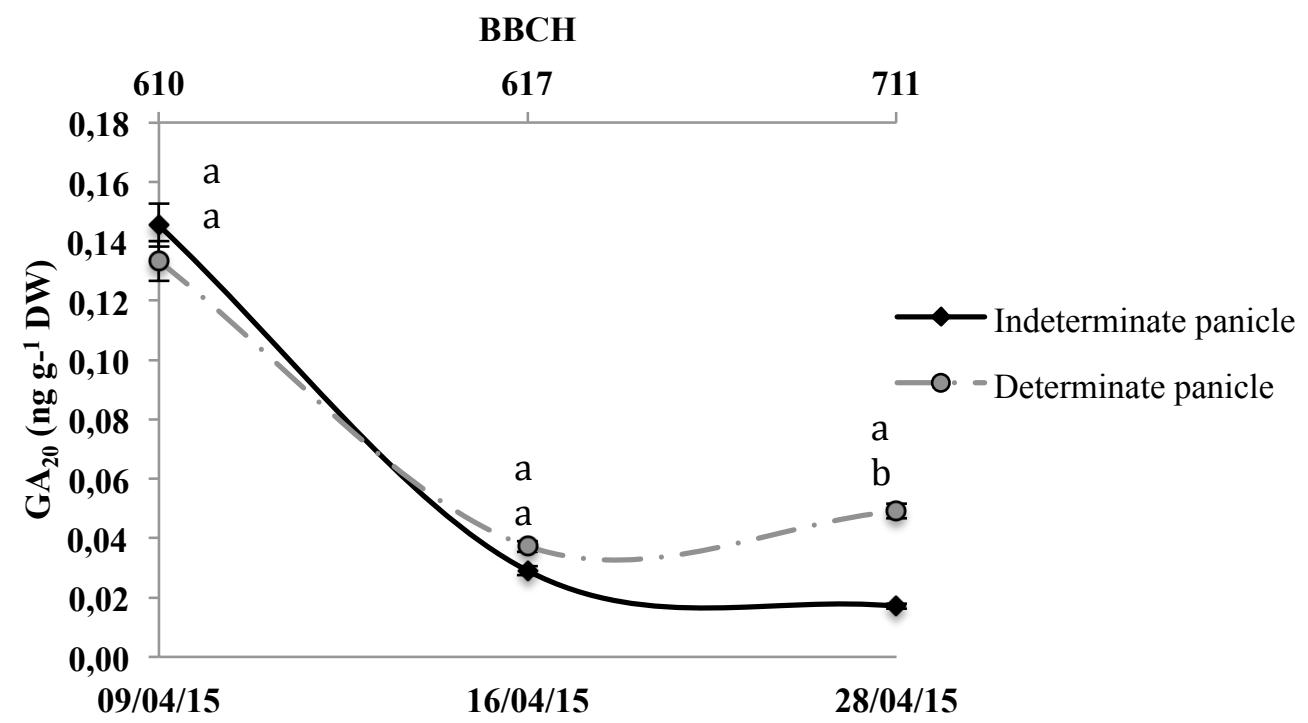

Figure 34: The time course of $\mathrm{GA}_{20}$ concentration in flower drop from indeterminate and determinate panicles in avocado trees $\mathrm{cv}$. Hass. Each point is the average of three replications. Vertical bars indicate standard error. Different letters indicate significant differences $(P \leq 0.05)$. The upper axis represents the phenological stages according to the $\mathrm{BBCH}$ scale.

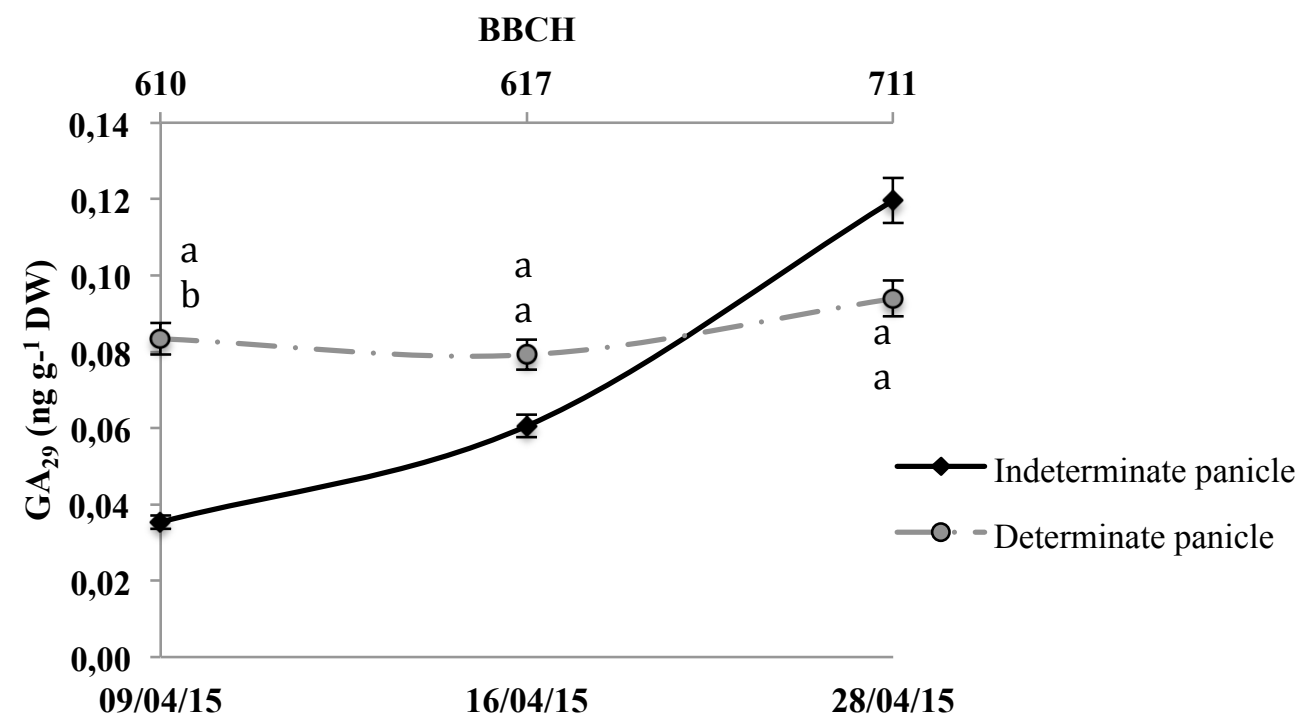

Figure 35: The time course of $\mathrm{GA}_{29}$ concentration in flower drop from indeterminate and determinate panicles in avocado trees cv. Hass. Each point is the average of three replications. Vertical bars indicate standard error. Different letters indicate significant differences $(P \leq 0.05)$. The upper axis represents the phenological stages according to the BBCH scale. 


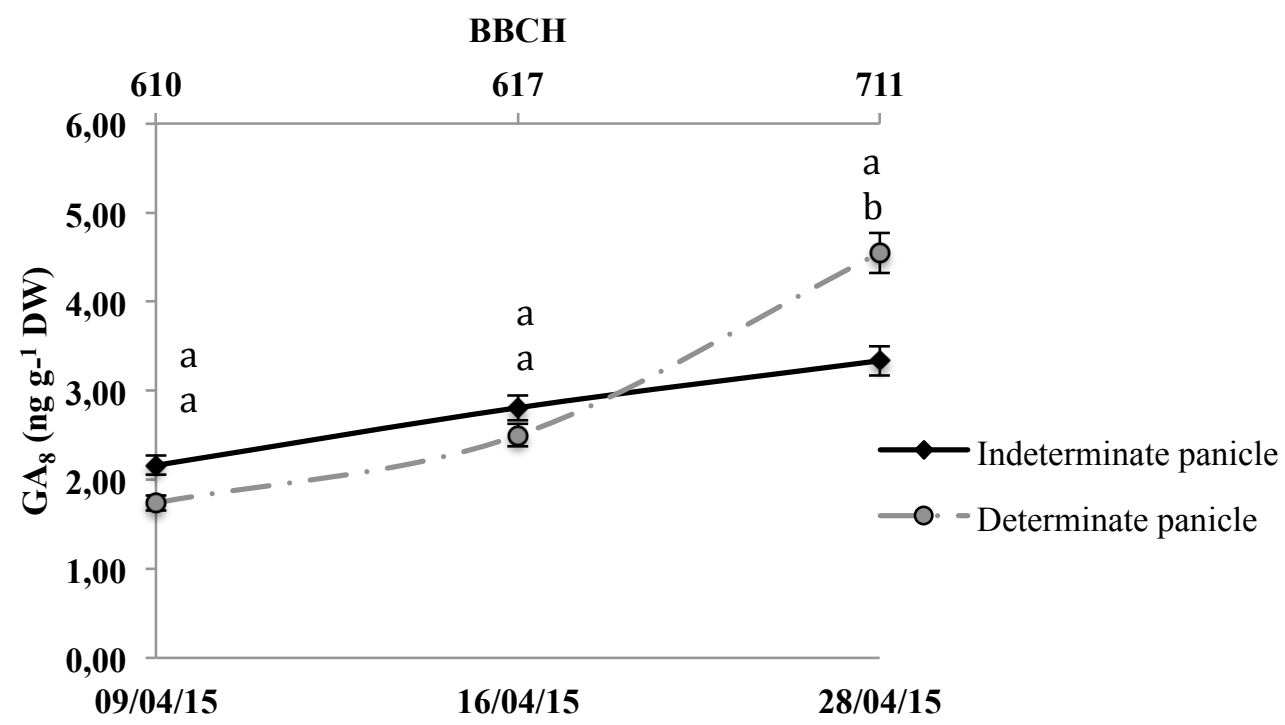

Figure 36: The time course of $\mathrm{GA}_{8}$ concentration in flower drop from indeterminate and determinate panicles in avocado trees cv. Hass. Each point is the average of three replications. Vertical bars indicate standard error. Different letters indicate significant differences $(P \leq 0.05)$. The upper axis represents the phenological stages according to the $\mathrm{BBCH}$ scale.

IAA concentration decreased over the period of flower abscission, especially those from determinate panicles. From anthesis until fruit set it decreased continuously, by $55 \%$ to the value of $34.4 \mathrm{ng} \mathrm{g}^{-1} \mathrm{DW}$ in the latter, while in flowers from indeterminate panicles reduction was $17 \%$ from anthesis to $617 \mathrm{BBCH}$, remaining constant until fruit set and reaching the value of $55.5 \mathrm{ng} \mathrm{g}^{-1} \mathrm{DW}$ (Figure 37). 


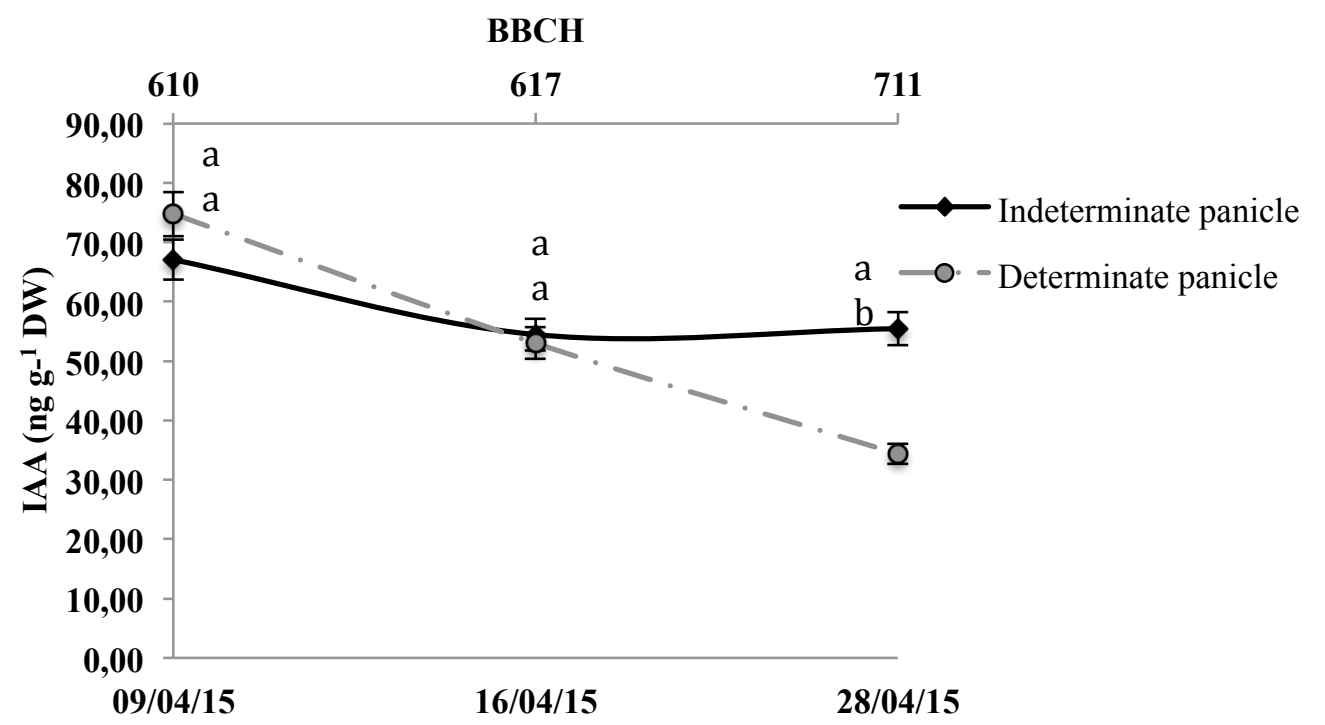

Figure 37: The time course of IAA concentration in flower drop from indeterminate and determinate panicles in avocado trees $\mathrm{cv}$. Hass. Each point is the average of three replications. Vertical bars indicate standard error. Different letters indicate significant differences $(P \leq 0.05)$. The upper axis represents the phenological stages according to the $\mathrm{BBCH}$ scale.

The concentration of cytokinin DHZ over period of flower abscission and even fruit set significantly increased to maximum values of 0.20 and $0.16 \mathrm{ng} \mathrm{g-}^{1} \mathrm{DW}$ (Figure 38), while iP significantly decreased to minimum values of 0.87 and 0.83 ng g ${ }^{-1}$ DW (Figure 39). But as it happened with gibberellins, these concentrations are extremely low as ascribe to significant importance in the development of flowers or in regulating its abscission. $t \mathrm{Z}$ concentration, however, metabolically showed high values over time and remained stable in the early stages of development, after reaching the minimum values coinciding with fruit set (Figure 40). $t \mathrm{Z}$ concentration remained higher in the flower from determinate panicles throughout the study period. 


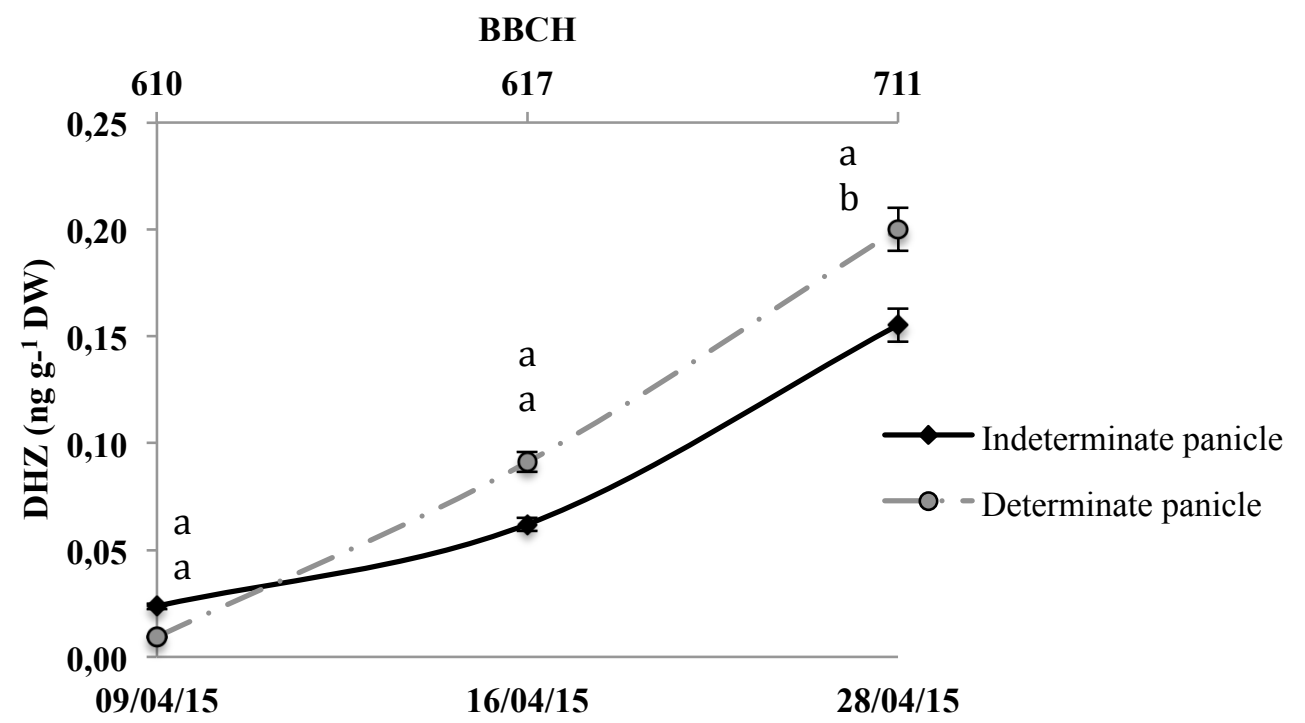

Figure 38: The time course of DHZ (dihydrozeatin) concentration in flower drop from indeterminate and determinate panicles in avocado trees cv. Hass. Each point is the average of three replications. Vertical bars indicate standard error. Different letters indicate significant differences $(P \leq 0.05)$. The upper axis represents the phenological stages according to the $\mathrm{BBCH}$ scale.

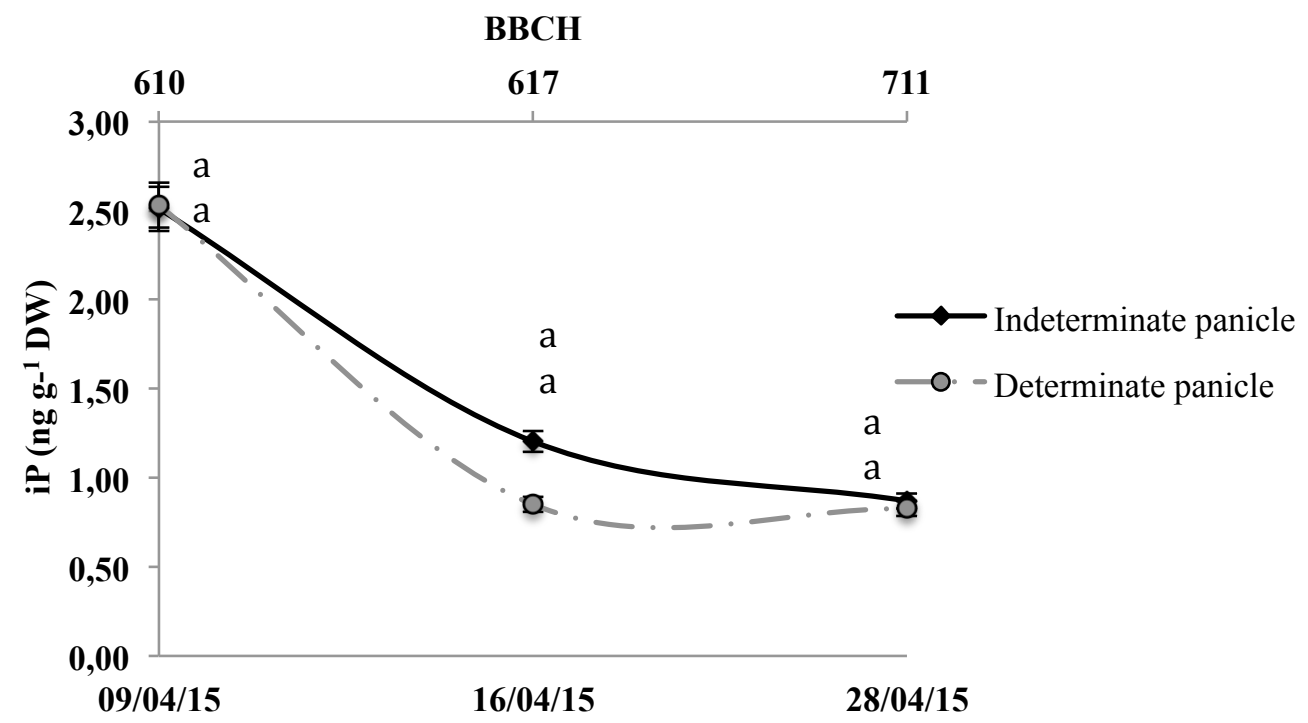

Figure 39: The time course of iP (2-isopentenyl-adenine) concentration in flower drop from indeterminate and determinate panicles in avocado trees cv. Hass. Each point is the average of three replications. Vertical bars indicate standard error. Different letters indicate significant differences $(P \leq 0.05)$. The upper axis represents the phenological stages according to the $\mathrm{BBCH}$ scale. 


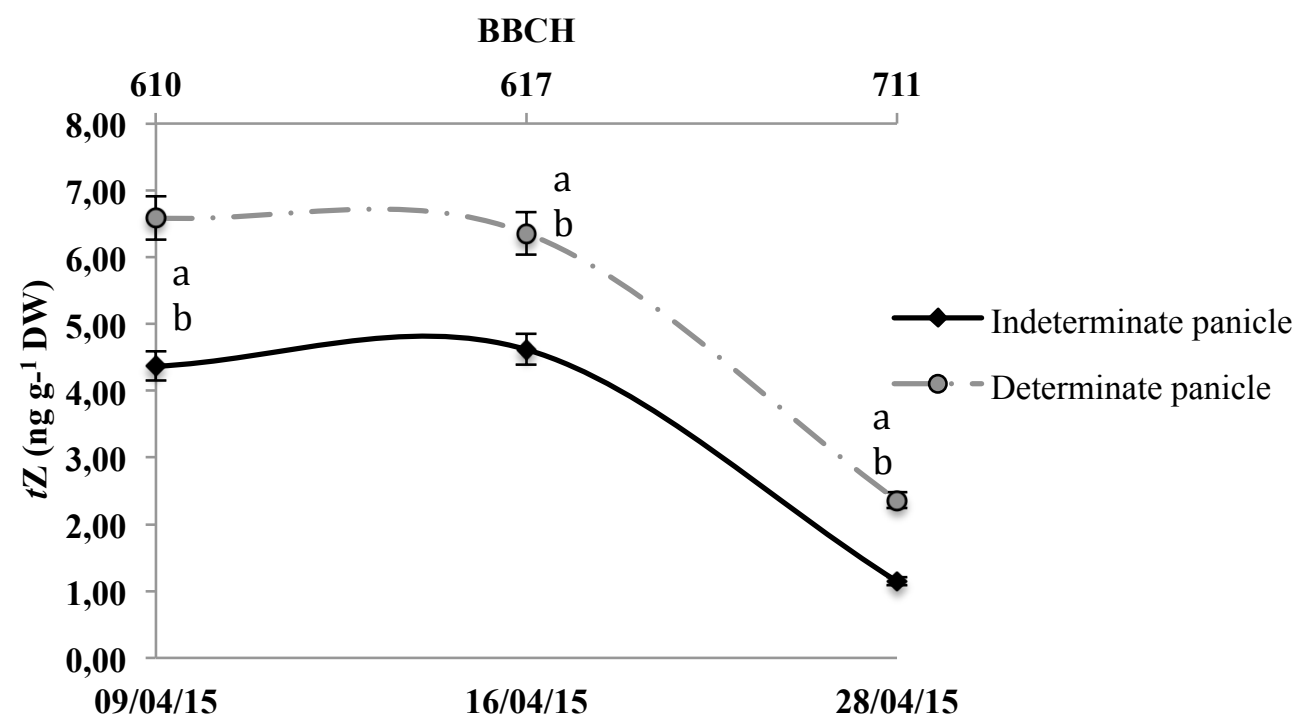

Figure 40: The time course of $t Z$ (trans-zeatin) concentration in flower drop from indeterminate and determinate panicles in avocado trees cv. Hass. Each point is the average of three replications. Vertical bars indicate standard error. Different letters indicate significant differences $(P \leq 0.05)$. The upper axis represents the phenological stages according to the $\mathrm{BBCH}$ scale.

\subsubsection{During the initial development of fruit}

The time course of the concentration on the fruits of gibberellins during his abscission was altered by the presence of the apical bud. In those located in determinate panicles, during the early stages of development the concentration of $\mathrm{GA}_{9}$ decreased (figure 41), as did that of his catabolite $\mathrm{GA}_{51}$ did (Figure 42). However, in the fruits of indeterminate panicle the concentration of GA9 significantly increased (Figure 41) and $\mathrm{GA}_{51}$ remained constant (Figure 42).

Gibberellins of the 13-hydroxylation route also showed differences in the fruits as they were in indeterminate or determinate panicles. The concentration of $\mathrm{GA}_{19}$ increased over time (Figure 43), and yet the concentration of its precursor, $\mathrm{GA}_{20}$, decreased (Figure 44), being the values of the fruits of indeterminate panicles superior to those of the determinate panicles in the first and lower in the second. The concentration of catabolite of the latter, $\mathrm{GA}_{29}$, was barely altered over time (Figure 45). Gibberellin $\mathrm{GA}_{1}$ was not detected in fruits, too, although its catabolite $\mathrm{GA}_{8}$, yes (Figure 46), which suggests, also in this case, that the path of the 13hydroxylation of gibberellins in the avocado fruits should be catabolic. What is more, its extremely low values, not exceeding $2.5 \mathrm{ng} \mathrm{g}^{-1} \mathrm{DW}$ and almost always lower than $1 \mathrm{ng} \mathrm{g}^{-1} \mathrm{DW}$, indicate a very little relevant role in the initial development of their fruits. 


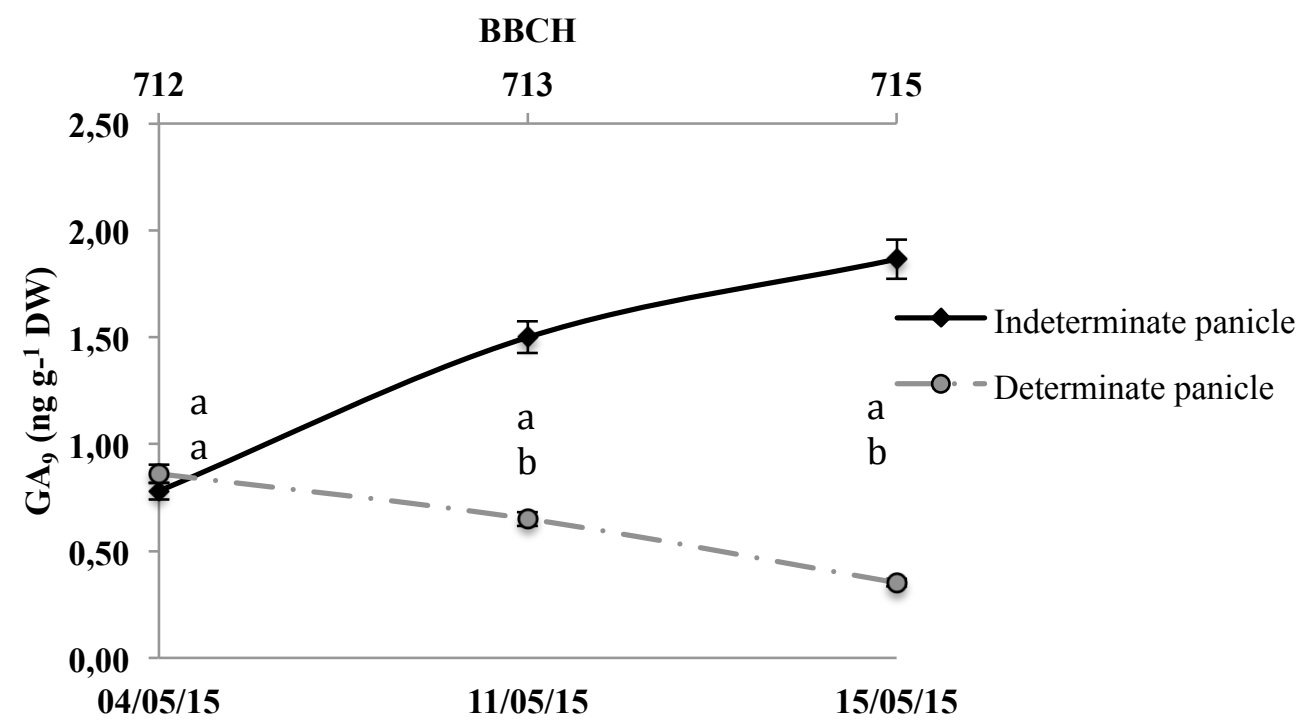

Figure 41: The time course of $\mathrm{GA}_{9}$ concentration in fruit drops from indeterminate and determinate panicles in avocado trees cv. Hass. Each point is the average of three replications. Vertical bars indicate standard error. Different letters indicate significant differences $(P \leq 0.05)$. The upper axis represents the phenological stages according to the $\mathrm{BBCH}$ scale.

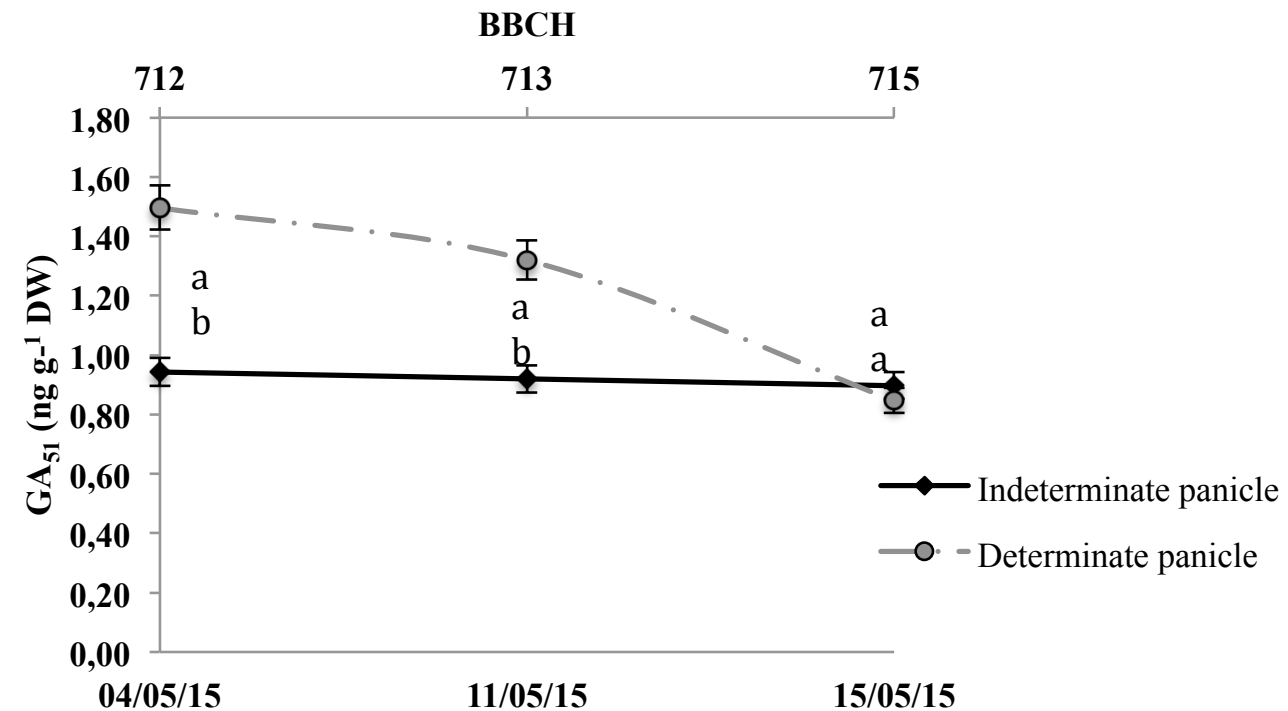

Figure 42: The time course of $\mathrm{GA}_{51}$ concentration in fruit drops from indeterminate and determinate panicles in avocado trees cv. Hass. Each point is the average of three replications. Vertical bars indicate standard error. Different letters indicate significant differences $(P \leq 0.05)$. The upper axis represents the phenological stages according to the $\mathrm{BBCH}$ scale. 


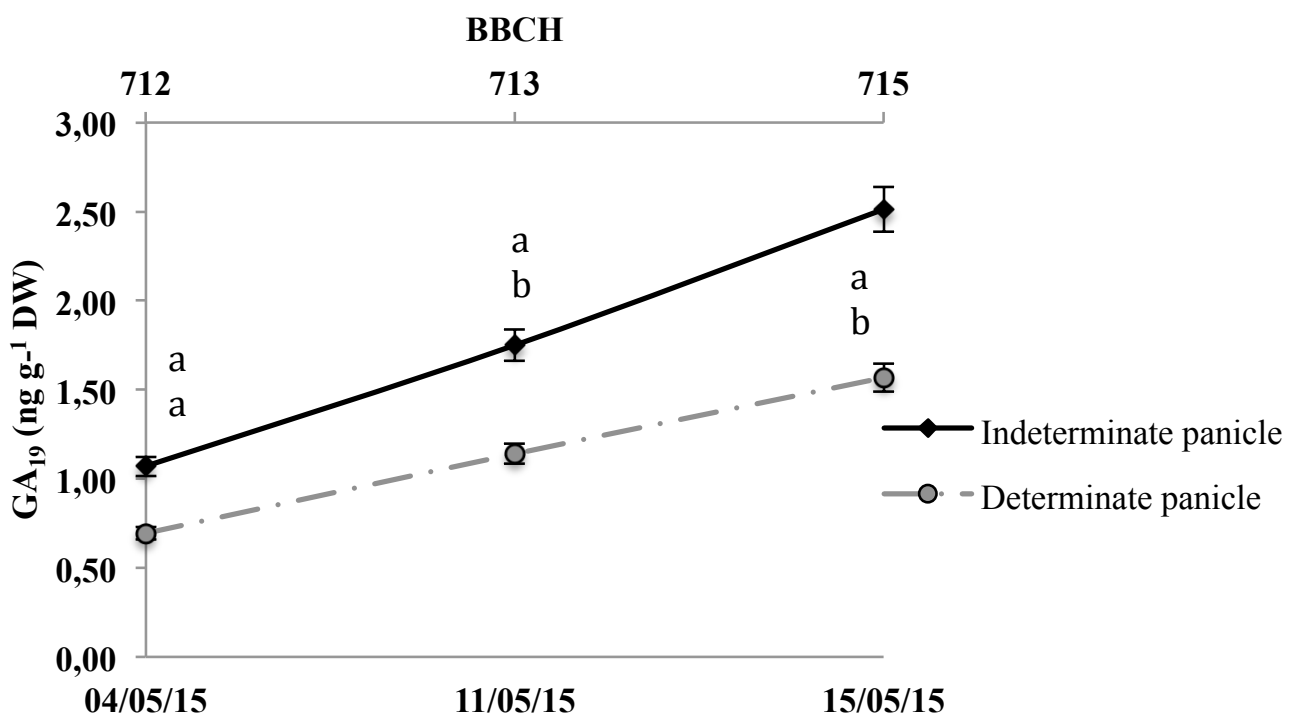

Figure 43: The time course of $\mathrm{GA}_{19}$ concentration in fruit drops from indeterminate and determinate panicles in avocado trees cv. Hass. Each point is the average of three replications. Vertical bars indicate standard error. Different letters indicate significant differences $(P \leq 0.05)$. The upper axis represents the phenological stages according to the $\mathrm{BBCH}$ scale.

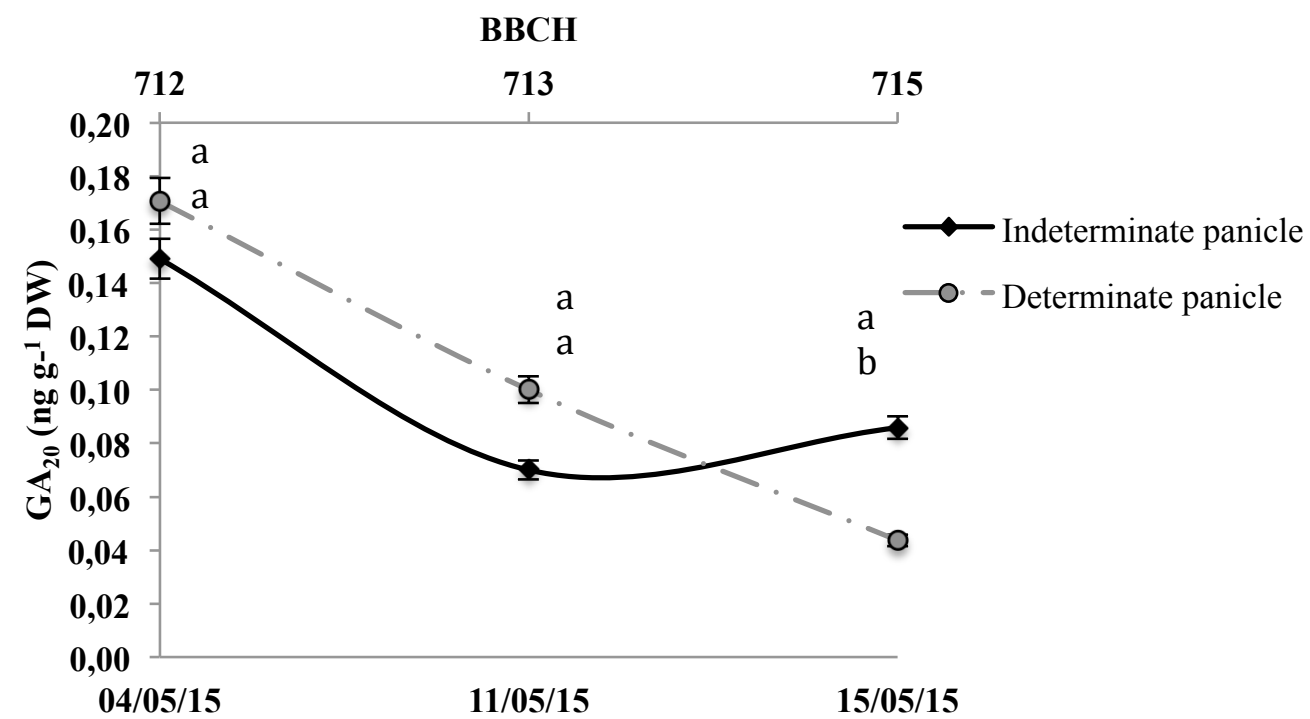

Figure 44: The time course of $\mathrm{GA}_{20}$ concentration in fruit drops from indeterminate and determinate panicles in avocado trees cv. Hass. Each point is the average of three replications. Vertical bars indicate standard error. Different letters indicate significant differences $(P \leq 0.05)$. The upper axis represents the phenological stages according to the BBCH scale. 


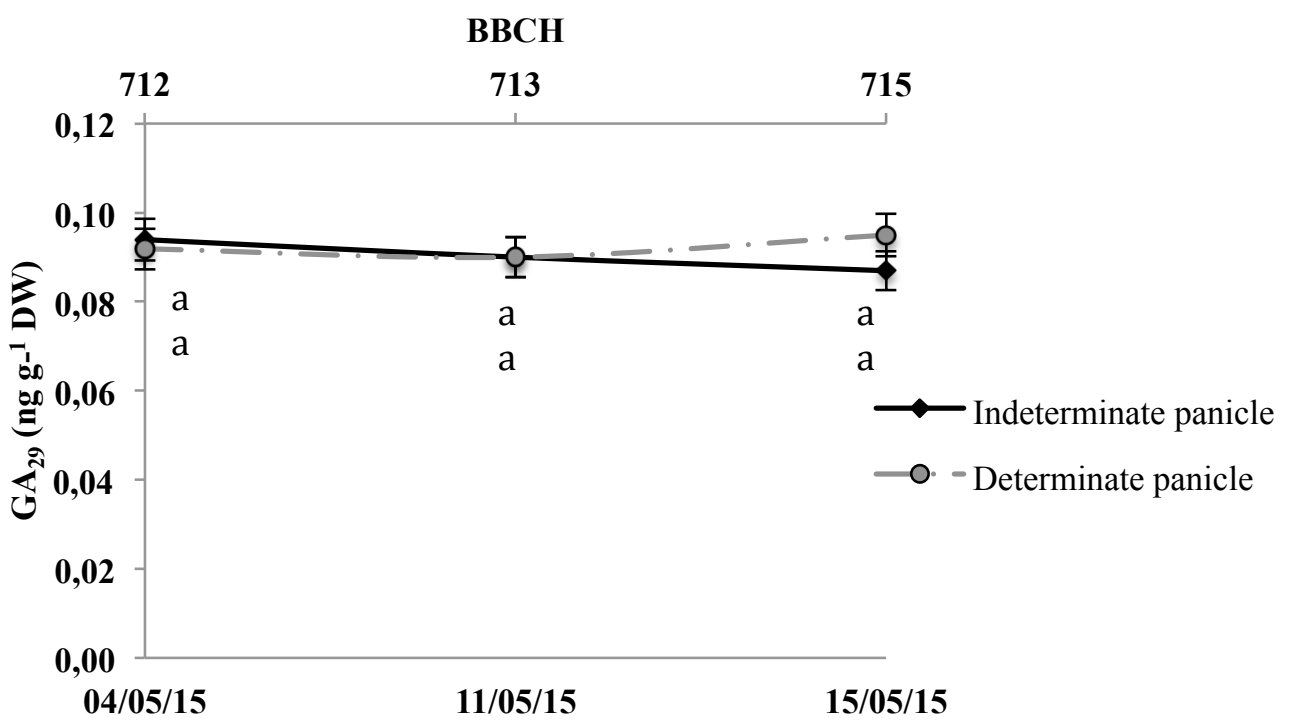

Figure 45: The time course of $\mathrm{GA}_{29}$ concentration in fruit drops from indeterminate and determinate panicles in avocado trees cv. Hass. Each point is the average of three replications. Vertical bars indicate standard error. Different letters indicate significant differences $(P \leq 0.05)$. The upper axis represents the phenological stages according to the $\mathrm{BBCH}$ scale.

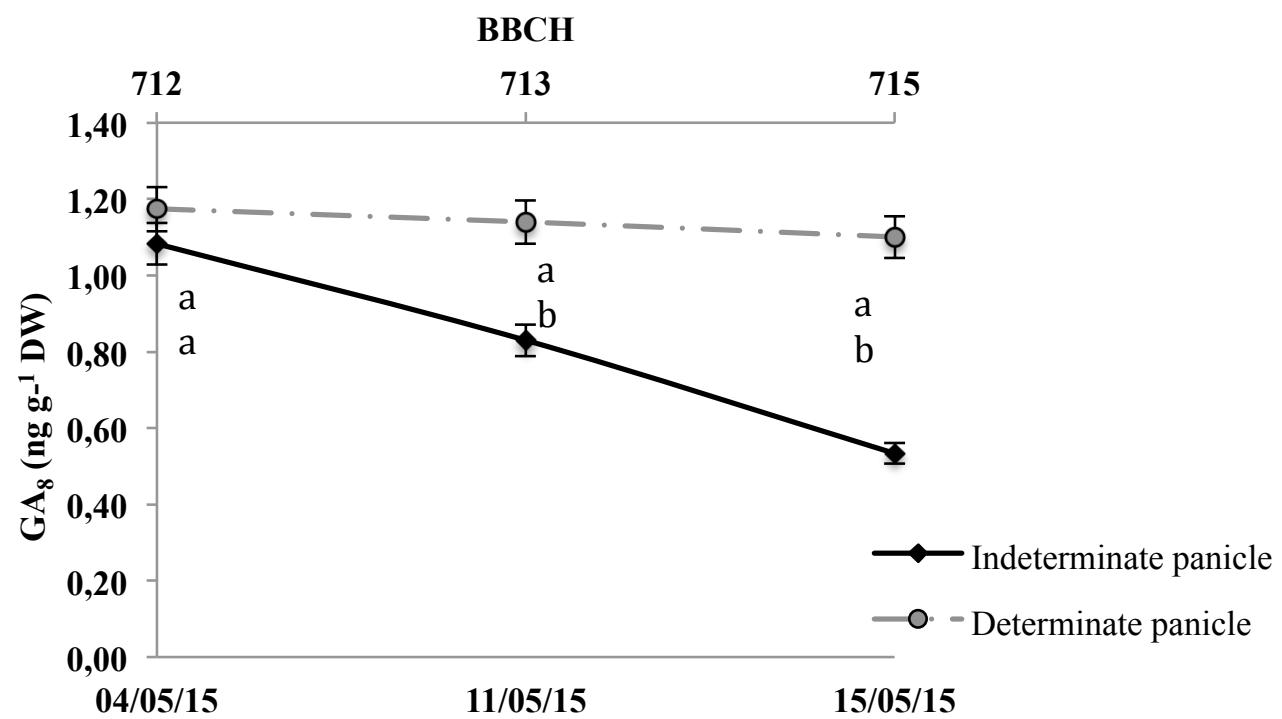

Figure 46: The time course of $\mathrm{GA}_{8}$ concentration in fruit drops from indeterminate and determinate panicles in avocado trees cv. Hass. Each point is the average of three replications. Vertical bars indicate standard error. Different letters indicate significant differences $(P \leq 0.05)$. The upper axis represents the phenological stages according to the BBCH scale.

The concentration of IAA increased steadily throughout the period of abscission of the fruits of the indeterminate panicles, while that of the fruits from determinate panicles remained constant (Figure 47). It is worth noting the relatively high values of this hormone in comparison with those of gibberellins. 


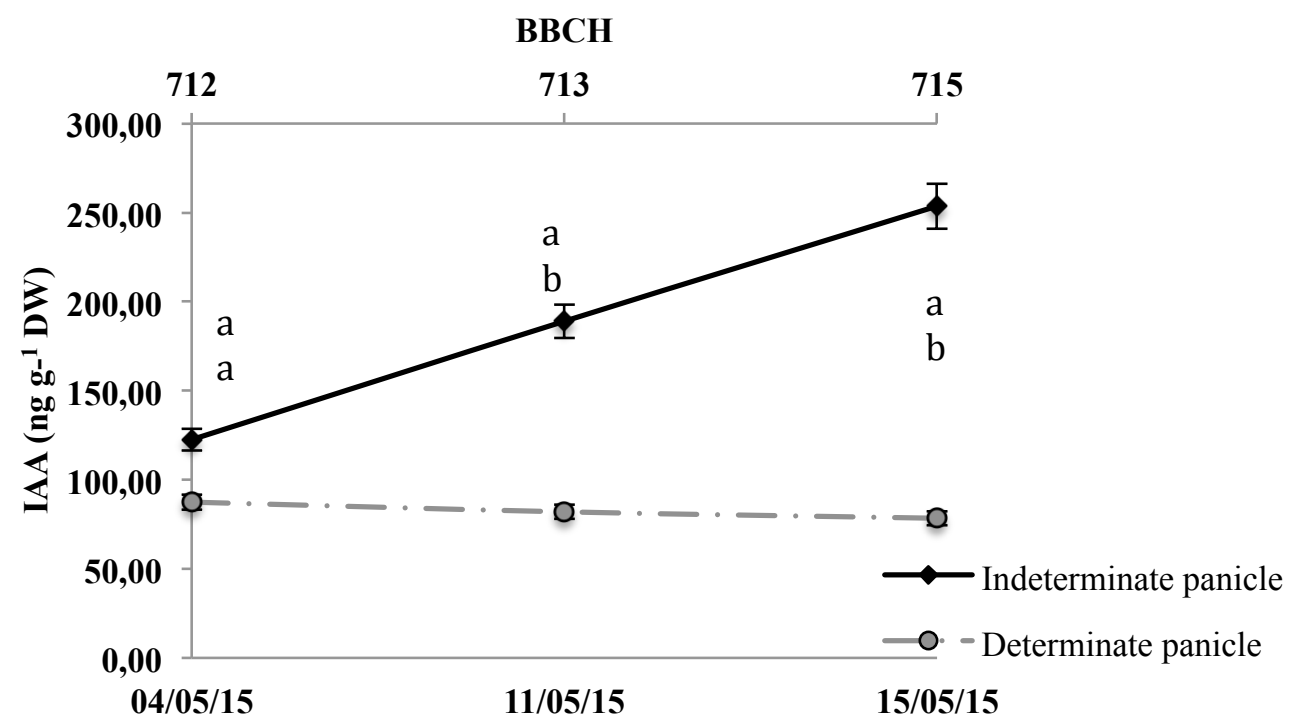

Figure 47: The time course of IAA concentration in fruit drops from indeterminate and determinate panicles in avocado trees cv. Hass. Each point is the average of three replications. Vertical bars indicate standard error. Different letters indicate significant differences $(P \leq 0.05)$. The upper axis represents the phenological stages according to the $\mathrm{BBCH}$ scale.

The concentration of cytokinins DHZ significantly increased throughout the abscission period of the fruits up to maximum values of 59.9 and $20.7 \mathrm{ng} \mathrm{g}^{-1} \mathrm{DW}$ in the fruits from indeterminate or determinate panicles, respectively (Figure 48).

The concentration of iP, however, decreased over the same period reaching minimum values of 1 and $0.77 \mathrm{ng} \mathrm{g}^{-1} \mathrm{DW}$ (Figure 49) in the fruits from indeterminate and determinate panicles, respectively.

Finally the $t \mathrm{Z}$ had a similar behaviour to that of the DHZ throughout the studied period, although with values markedly higher, reaching average values of 552.39 and $208.05 \mathrm{ng} \mathrm{g}^{-1} \mathrm{DW}$ for those from indeterminate and determinate panicles, respectively (Figure 50).

As in the case of the IAA, the concentration of the cytokinins DHZ and particularly the $t Z$ were markedly higher than those of gibberellins. 
BBCH

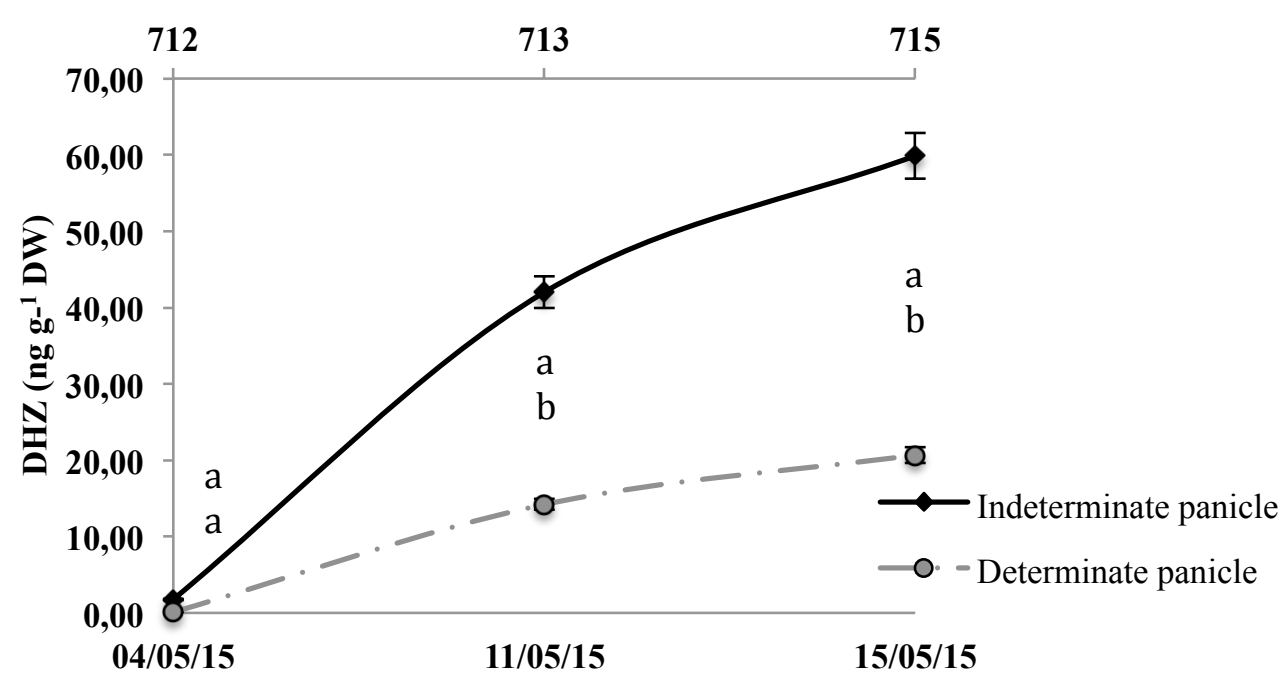

Figure 48: The time course of $\mathrm{DHZ}$ concentration in fruit drops from indeterminate and determinate panicles in avocado trees cv. Hass. Each point is the average of three replications. Vertical bars indicate standard error. Different letters indicate significant differences $(P \leq 0.05)$. The upper axis represents the phenological stages according to the $\mathrm{BBCH}$ scale.

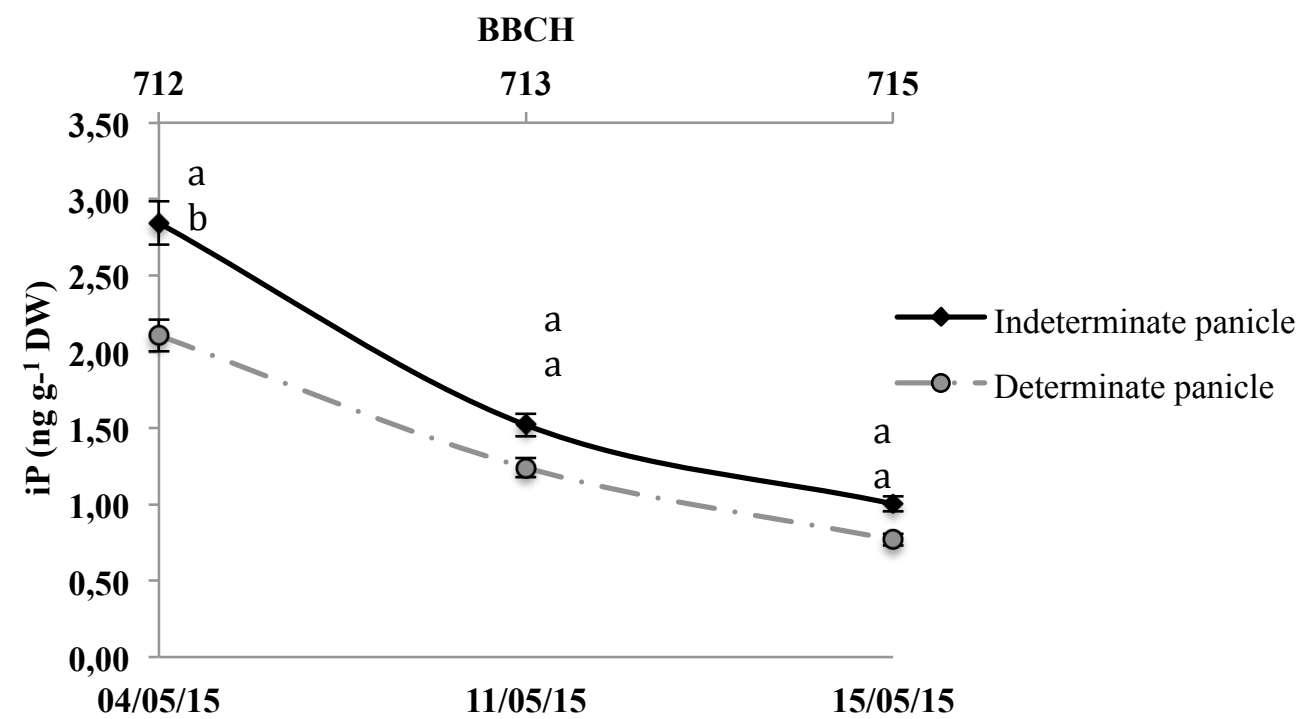

Figure 49: The time course of iP concentration in fruit drops from indeterminate and determinate panicles in avocado trees cv. Hass. Each point is the average of three replications. Vertical bars indicate standard error. Different letters indicate significant differences $(P \leq 0.05)$. The upper axis represents the phenological stages according to the $\mathrm{BBCH}$ scale. 


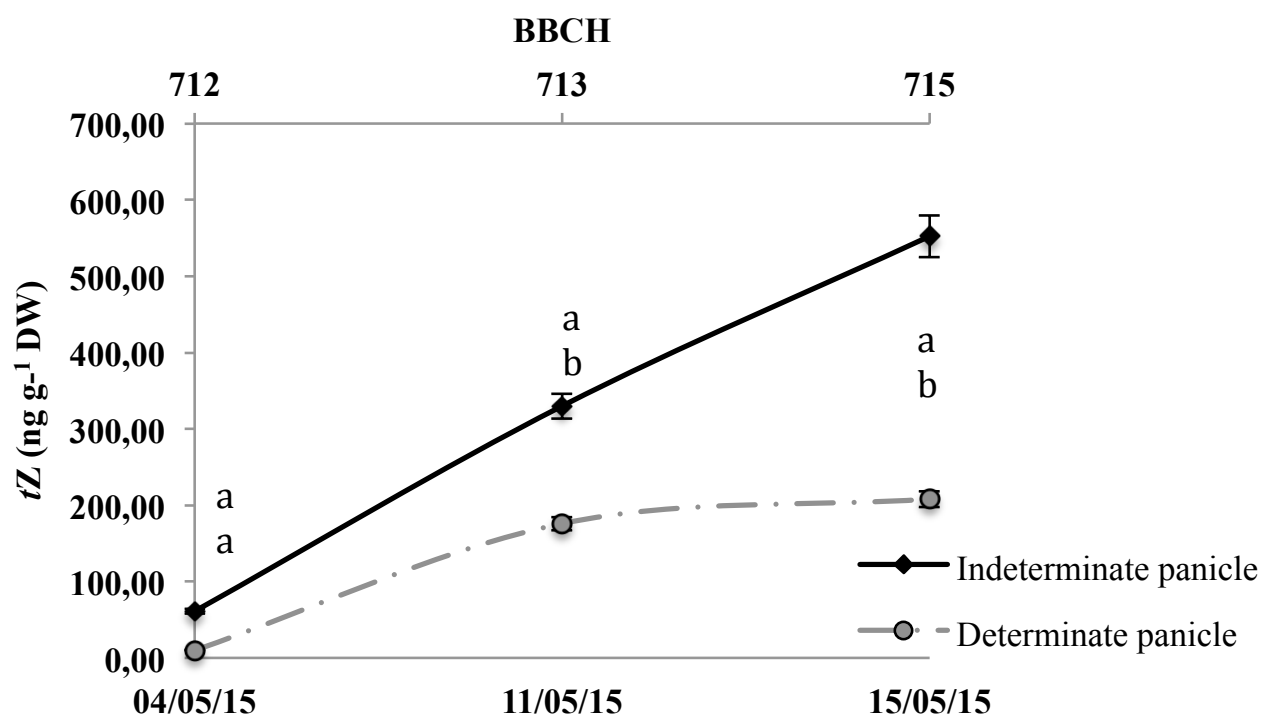

Figure 50: The time course of $t \mathrm{Z}$ concentration in fruit drops from indeterminate and determinate panicles in avocado trees cv. Hass. Each point is the average of three replications. Vertical bars indicate standard error. Different letters indicate significant differences $(P \leq 0.05)$. The upper axis represents the phenological stages according to the $\mathrm{BBCH}$ scale.

\section{EXSOGENUS CONTROL OF THE ABSCISSION OF REPRODUCTIVES ORGANS}

\subsection{Influence of $\mathrm{GA}_{3}$ and PBZ on the abscission of flowers and fruits. Action of ringing}

The application of PBZ (50 $\mathrm{mg}^{-1}$ ) to individual inflorescences when $10 \%$ of flowers on the panicle were open promoted and advanced the flowers abscission (Figure 51). Thus, while from inflorescences control and treated with GA one week after the treatment $35 \%$ of flowers had dropped, while in those treated with PBZ $60 \%$. Seven days later while in the first group 30\% of the flowers still remained, from the latter virtually all of them had already dropped. However, a significant anticipation of the abscission of flowers by effect of PBZ, no differences were found between the treatments at the time of the fruit set (phenological state $711 \mathrm{BBCH}$ ) in which $97.5 \%$ of the flowers had dropped in all of them (Figure 51). 


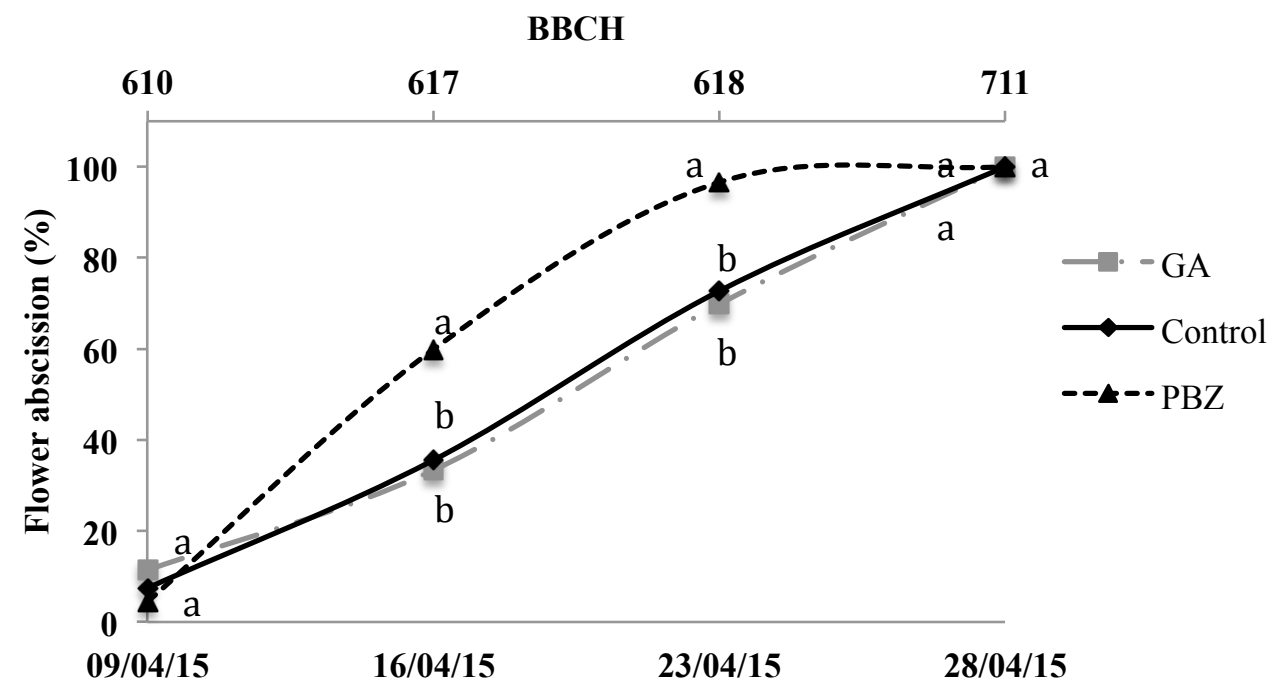

Figure 51: Influence of the application of inhibitors (PBZ $50 \mathrm{mg}^{-1}$ ) and promoters (GA $50 \mathrm{mg}^{-1}$ ) of development to individual inflorescences in the abscission of the flowers of cv. Hass avocado in Llaurí (Valencia). The application was carried out in the state $610 \mathrm{BBCH}$ scale $(10 \%$ of the flowers were open). Each value is the average of 10 thyrsi. The standard error was smaller than the symbol. Different letters for a same date indicate significant differences $(\mathrm{P} \leq 0.05)$. The upper shaft represents the phenological states according to the BBCH scale. PBZ: paclobutrazol; GA: gibberellic acid. Date of treatments: April 9, 2015.

The effectiveness of these treatments on the abscission of fruits was null. Thus, in Llaurí, one week after fruit set (phenological state $712 \mathrm{BBCH}$ ) almost $100 \%$ of the fruits had already dropped independently from the treatment received (Figure 52). In Caronia Marina, ten days after fruit set $35 \%$ of the fruits had already dropped, arriving at $72 \%$ a month later, without significant differences between treatments (Figure 53). At the end of the period of abscission, the fruits that were maintained in the plant were 1-2 per inflorescence, approximately, in both farms. 


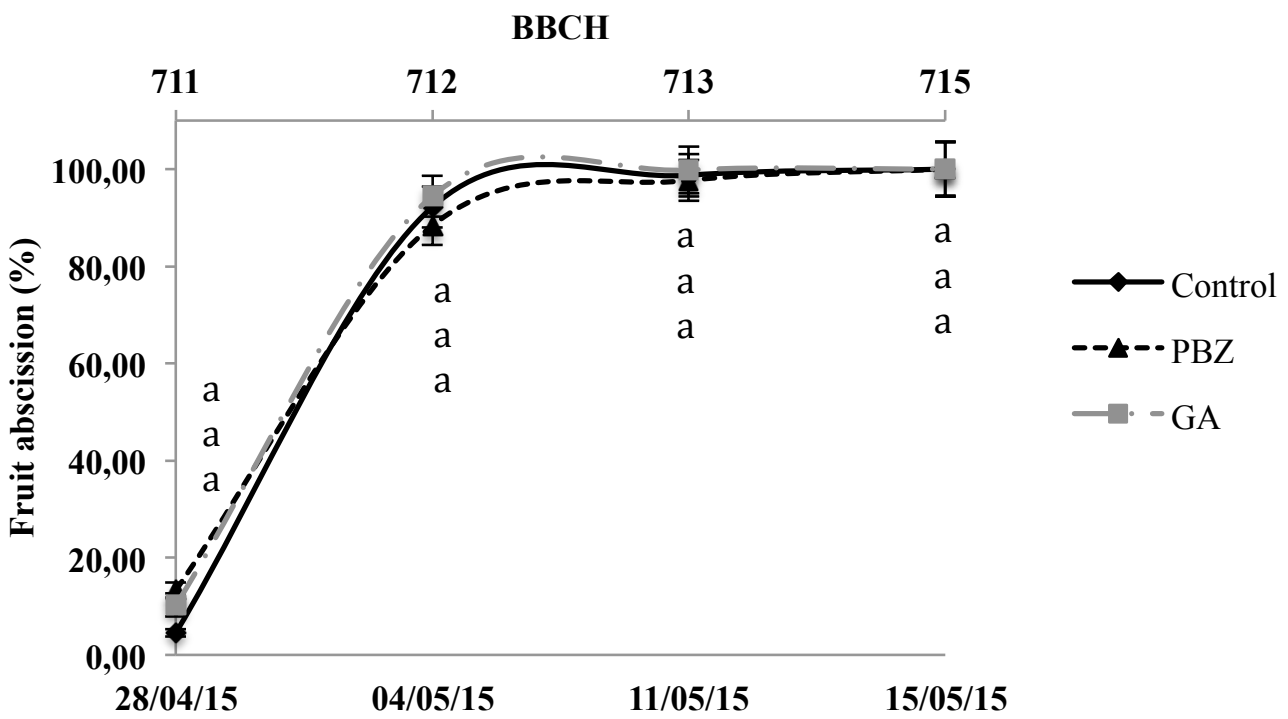

Figure 52: Influence of the application of inhibitors (PBZ $50 \mathrm{mg} \mathrm{l}^{-1}$ ) and promoters (GA $50 \mathrm{mg} \mathrm{l}^{-1}$ ) of development to individual inflorescences in the abscission of the fruits of cv. Hass avocado in Llaurí (Valencia). The application was carried out in the state $610 \mathrm{BBCH}$ scale $(10 \%$ of the flowers were open). Each value is the average of 10 thyrsi. The standard error was smaller than the symbol. Different letters for a same date indicate significant differences $(\mathrm{P} \leq 0.05)$. The upper shaft represents the phenological states according to the BBCH scale. PBZ: paclobutrazol; GA: gibberellic acid. Date of treatments: April 9, 2015.

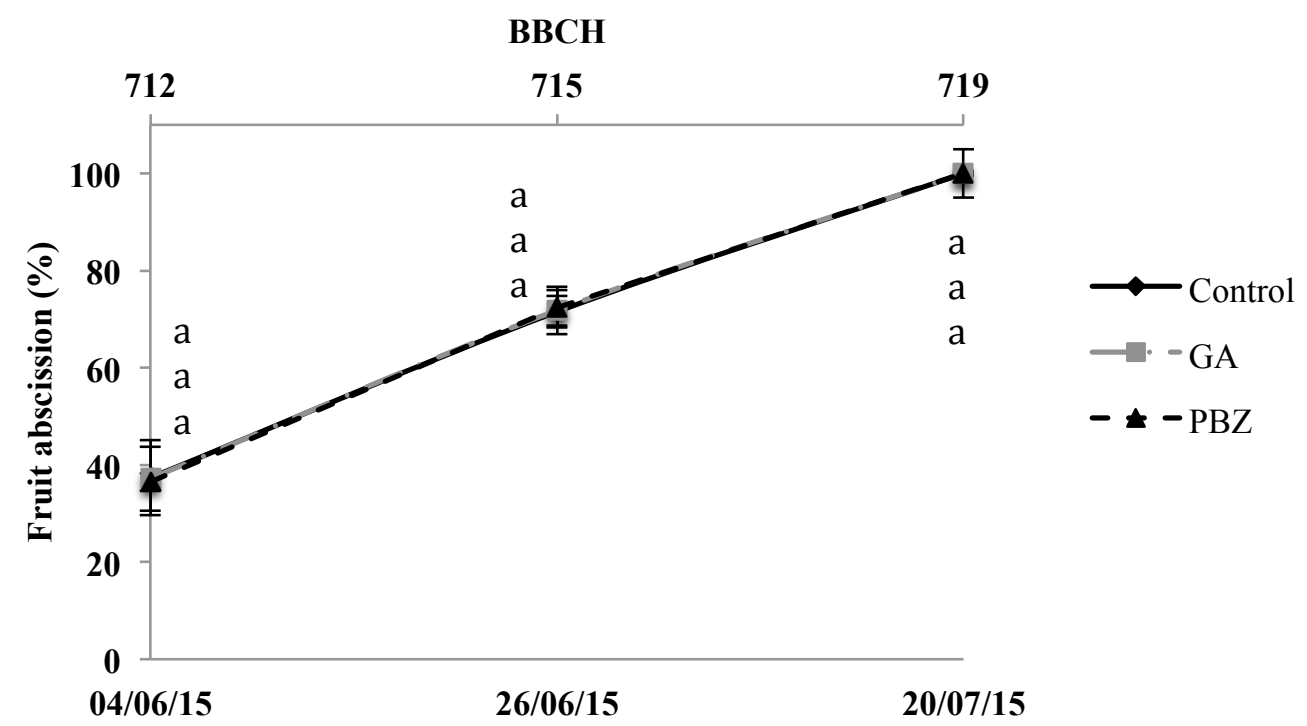

Figure 53: Influence of the application of inhibitors (PBZ $50 \mathrm{mg} \mathrm{l}^{-1}$ ) and promoters (GA $50 \mathrm{mg} \mathrm{l}^{-1}$ ) of development to individual inflorescences in the abscission of the fruits of $\mathrm{cv}$. Hass avocado in Caronia Marina (Messina). The application was carried out in the state $711 \mathrm{BBCH}$ scale. Each value is the average of 10 thyrsi. The standard error was smaller than the symbol. Different letters for a same date indicate significant differences $(\mathrm{P} \leq 0.05)$. The upper shaft represents the phenological states according to the BBCH scale. PBZ: paclobutrazol; GA: gibberellic acid. Date of treatments: May 25, 2015.

The application to the entire tree of both fitohormones, to the same concentration and in the same phenological state ( $10 \%$ of open flowers), gave rise to a similar 
response. Thus, 15 days after the application the trees treated with PBZ had 5.7 fruits per panicle on average, while those treated with GA had an average close to 10 fruits per panicle, like control trees (Figure $54 \mathrm{~A}$ ). A week later, while the trees treated with GA and the control almost the same number of fruits per panicle remained, while in those treated with PBZ it what significantly reduced until 1.2, keeping it so until the end of the study.

The ringing, parallel to the PBZ, also significantly reduced the number of fruits set up to 3 on this same date, and 10 days later both treatments had no significant differences between themselves or with the control, while the trees treated with GA still had 6 fruits per panicle. Twenty days later (50 days after treatment) differences between treatments had disappeared (Figure $54 \mathrm{~A}$ ) and all treatments showed the same average number of fruits, 1 per panicle.

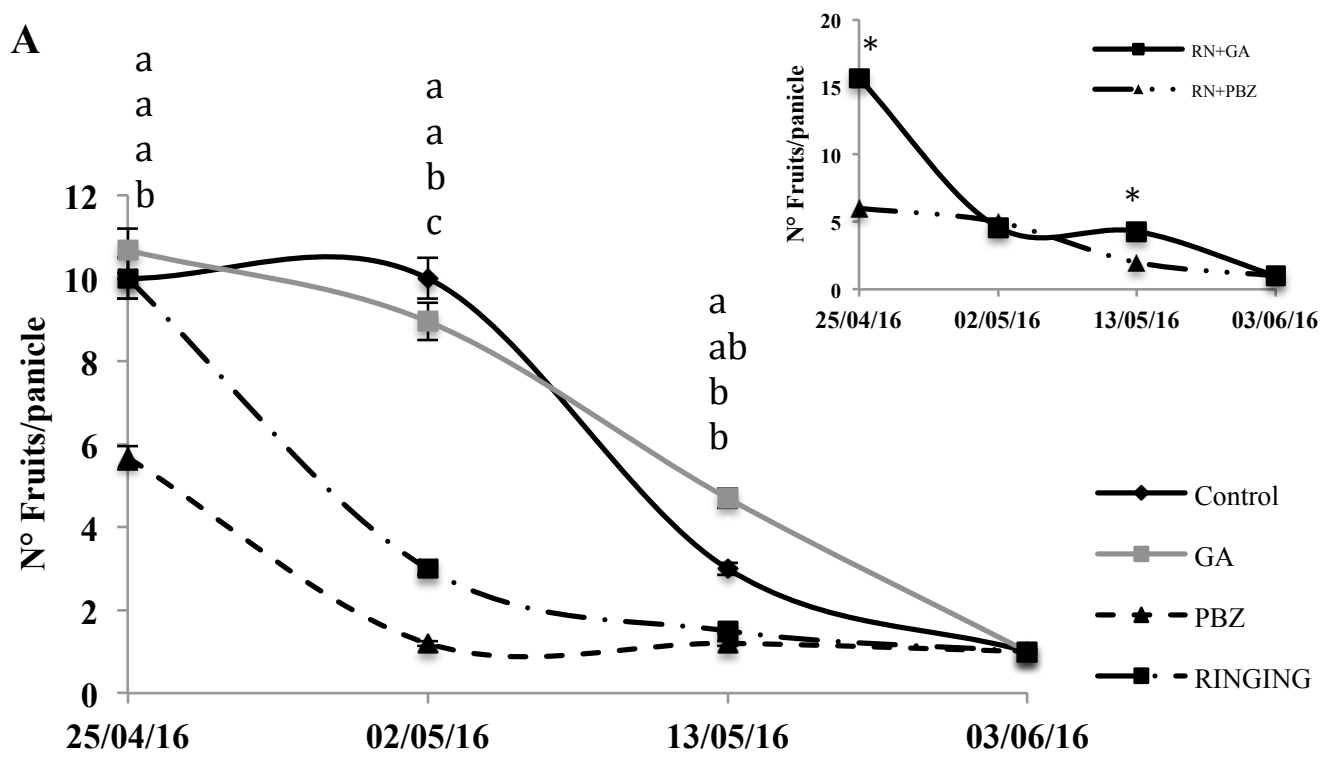


B

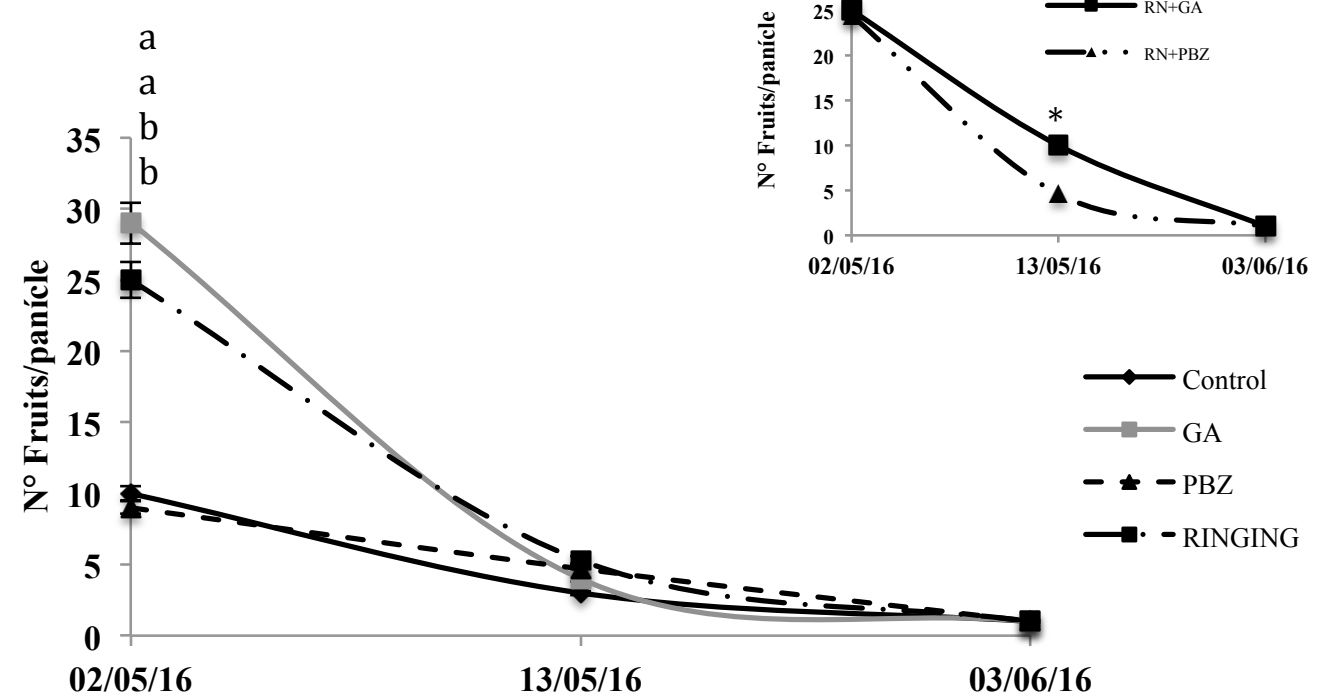

Figure 54: Influence of the application of GA $\left(50 \mathrm{mg} \mathrm{l}^{-1}\right)$ and PBZ $\left(50 \mathrm{mg}^{-1}\right)$ and the ringing on the time course of the number of fruits per panicle. Treatments were carried out in anthesis $11 / 04 / 2016$ (phenological state 610 of BBCH scale) (A) and at the time of the fruit set 26/04/2016 (Ø $3 \mathrm{~mm}$, phenological state 711 of $\mathrm{BBCH}$ scale) (B). Each value is the average of 8 panicles. The vertical bars indicate the standard error. Different letters or * for a same date indicate significant differences $(\mathrm{P} \leq 0.05)$. $\mathrm{GA}=$ gibberellic acid, $\mathrm{PBZ}=$ paclobutrazol, $\mathrm{RN}=$ Ringing.

It is worth noting that the combination of treatments, that is the application of GA or PBZ to previously ringed trees, did not significantly improve the response (Figure $54 \mathrm{~A}$ ). Only the first of them, to the 15 days of treatment, significantly increased the number of fruits set (16 fruits per panicle) over the ringing, the GA and control (10 fruits per panicle, on average), but these differences were lost in time.

The same treatments made 15 days later, when $80 \%$ of the fruits of the panicle had a diameter of $3 \mathrm{~mm}$ (phenological state $711 \mathrm{BBCH}$ ), obtained, however, different answers (Figure $54 \mathrm{~B}$ ). In this case it was immediate and 5 days after treatment the GA and the ringing had significantly increased the number of fruits set (29 and 25 respectively) concerning the PBZ (9 fruits per panicle) and control (10 fruits per panicle). But ten days later the response to the treatments were matched and all the panicles, regardless of treatment, presented 5 fruits per average, value that was eventually reduced to 1 fruit per panicle (Figure $54 \mathrm{~B}$ ).

Also in this case the combination of treatments, ringing $+\mathrm{GA}$ or ringing $+\mathrm{PBZ}$, managed to significantly improve the response. 


\subsection{Influence of $\mathrm{GA}_{3}$ and $\mathrm{PBZ}$ on individual panicles.}

\subsubsection{On the vegetative development}

The application of GA directly to the inflorescences of avocado cv. Hass with vegetative bud terminal, significantly increased the length of the shoot compared to those treated with PBZ and those of the control. Approximately 90 and 60 days after the treatment, when the fruit had already reached $40 \%$ of its final size (phonological states 715 and $719 \mathrm{BBCH}$ scale), it measured $28.2 \mathrm{~cm}$ in Llaurí and $32.6 \mathrm{~cm}$ in Caronia Marina, while those treated with PBZ and control, both measured in Llaurí $11.0 \mathrm{~cm}$, and 26 and $21.8 \mathrm{~cm}$ in Caronia Marina, respectively (Figures 55 and 56). The response to the GA was immediate and 7 days after treatment the shoots were already practically double those treated with PBZ and control. Contrary to what was expected, the PBZ did not reduce the length of the shoot in respect of the control.

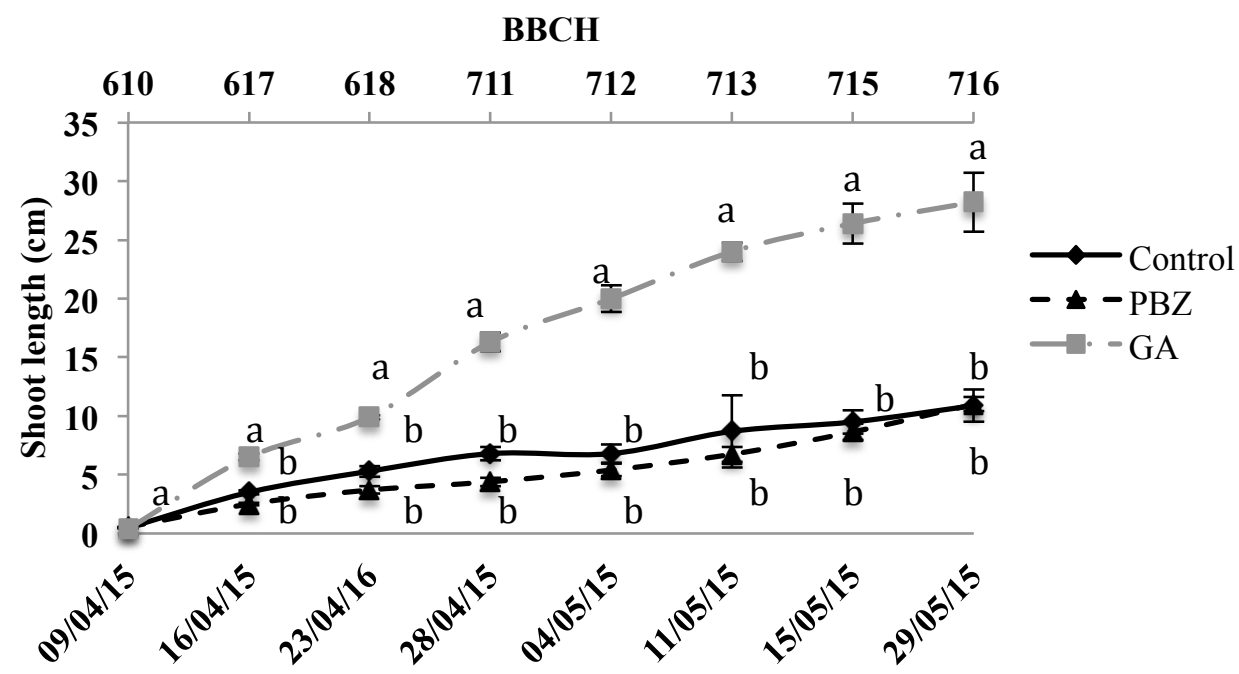

Figure 55: Influence of the application of inhibitors (PBZ $50 \mathrm{mg} \mathrm{l}^{-1}$ ) and promoters (GA $50 \mathrm{mg}^{-1}$ ) of development to individual inflorescences in the vegetative growth of avocado cv. Hass cultivated in Llaurí. The application was carried out in the state $610 \mathrm{BBCH}$, when $10 \%$ of the flowers were open. Each point is the average of 10 shoots. The vertical bars indicate the standard error. Different letters for a same date indicate significant differences $(\mathrm{P} \leq 0.05)$. The upper shaft represents the phenological states according to the $\mathrm{BBCH}$ scale. Date of treatments: April 9, 2015. 
BBCH

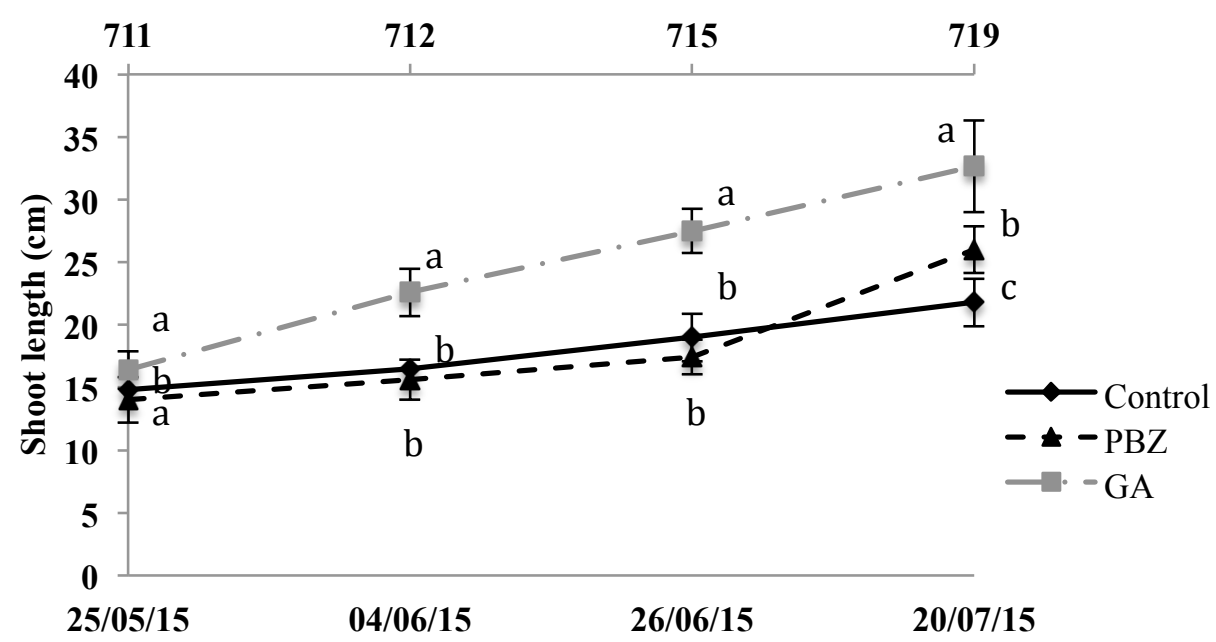

Figure 56: Influence of the application of inhibitors (PBZ $50 \mathrm{mg}^{-1}$ ) and promoters (GA $50 \mathrm{mg}^{-1}$ ) of development to individual inflorescences in the vegetative growth of avocado cv. Hass cultivated in Caronia Marina. The application was carried out in the state $711 \mathrm{BBCH}$. Each point is the average of 10 shoots. The vertical bars indicate the standard error. Different letters for a same date indicate significant differences $(\mathrm{P} \leq 0.05)$. The upper shaft represents the phenological states according to the BBCH scale. Date of treatments: May 25, 2015.

The treatments made on the entire tree also affected the length of the shoot of the terminal bud of the panicle regardless of the period in which they were performed. Thus, 15 days after the treatment, shoots treated with GA and ringing were already significantly longer $(5.3 \mathrm{~cm}$ on average) than those treated with PBZ and control $(3.6 \mathrm{~cm})$ (Figure 57 A). These differences were more significant a week later, but in the case of ringing were lost in the following, in which only the trees treated with GA maintained them. This difference remained significant until the end of the study period, introducing shoots up to $4 \mathrm{~cm}$ longer, on average, than the rest of the treatment (Figure $57 \mathrm{~A}$ ). The combination of the treatments was also ineffective in this case (data not shown).

The realization of the treatments 15 days later, when $80 \%$ of the fruit had a diameter of $3 \mathrm{~mm}$, barely changed the response. Thus, 7 days after the treatment the trees treated with GA submitted longer shoots $(7.2 \mathrm{~cm})$, followed by the ringing $(5.4 \mathrm{~cm})$, and those in turn of the control trees $(5.1 \mathrm{~cm})$ and treated with PBZ $(4.3 \mathrm{~cm})$ (Figure $57 \mathrm{~B}$ ). This trend was maintained throughout the study period and at the end of the same (38 days after the treatment) shoots of the trees treated with GA measured around $1 \mathrm{~cm}$ more than the controls and ringing and up 
to $3 \mathrm{~cm}$ more than those treated with PBZ (Figure $57 \mathrm{~B}$ ). In this case, only the ringing + GA managed to increase in $1.5 \mathrm{~cm}$, on average, the length of the shoot developed from the terminal bud of the panicle in respect of GA applied in solitaire (data not shown).
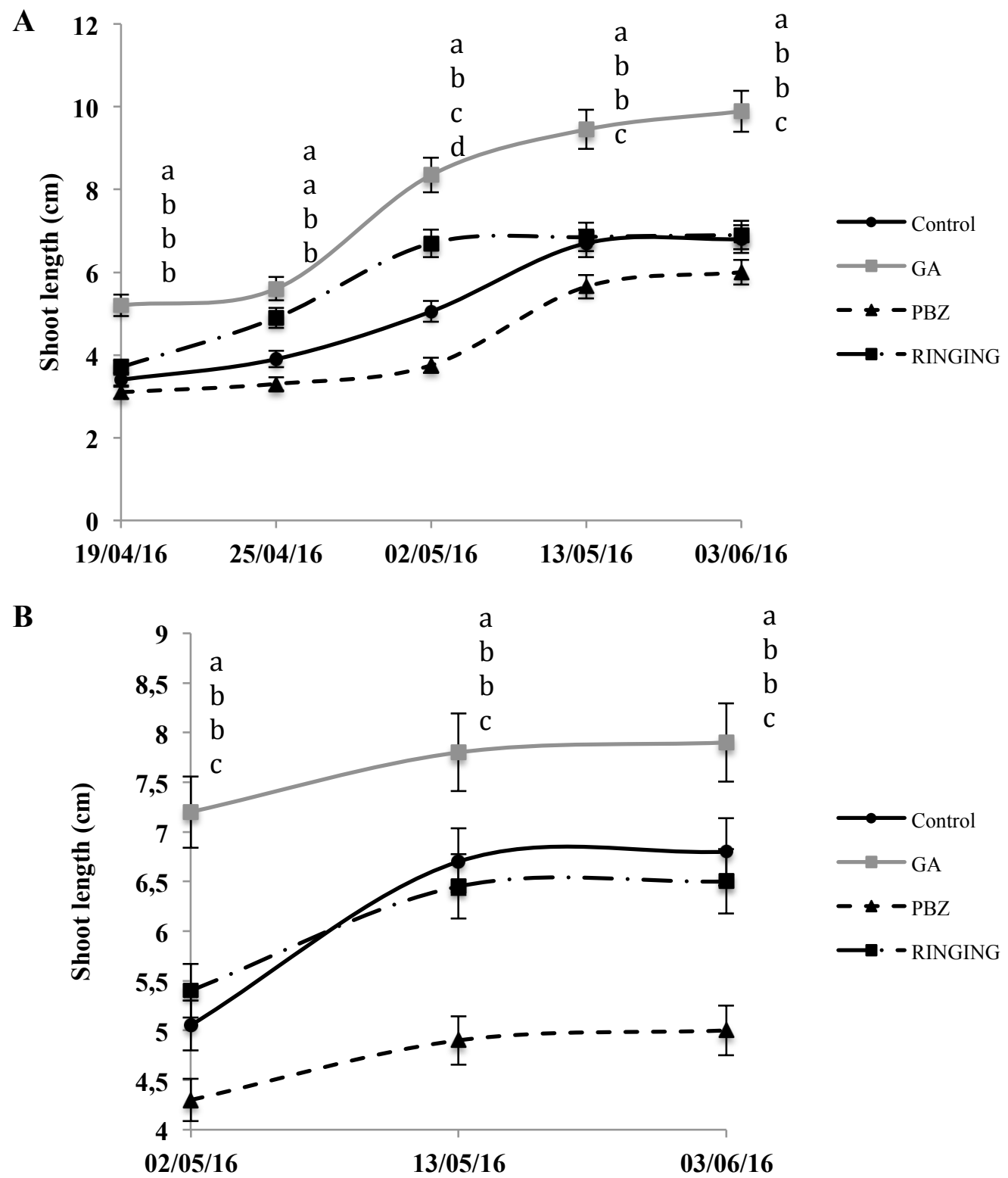

Figure 57: Influence of the application of GA $\left(50 \mathrm{mg} \mathrm{l}^{-1}\right)$ and PBZ $\left(50 \mathrm{mg} \mathrm{l}^{-1}\right)$ to entire the tree and the ringing on the time course of the length of the shoot developed from the terminal bud of the vegetative panicle. Treatments were carried out in anthesis 11/04/2016 (phenological state 610 of $\mathrm{BBCH}$ scale) (A) and at the time of the fruit set 26/04/2016 (Ø 3mm, phenological state 711 of $\mathrm{BBCH}$ scale) (B). Each value is the average of 8 shoots. The vertical bars indicate the standard error. Different letters for a same date indicate significant differences $(\mathrm{P} \leq 0.05)$. $\mathrm{GA}=$ gibberellic acid, $\mathrm{PBZ}=$ paclobutrazol, Ringing.

In the light of the results, the time of treatment, whether it is the same or not, has an impact on the final size of the shoot. Thus, shoots of trees treated in anthesis 
(phenological state 610 of the $\mathrm{BBCH}$ scale) presented a greater length than the treaties at the time of fruit set (phenological state 711 of the $\mathrm{BBCH}$ scale), with the exception of those treated with PBZ and ringing (Figure 58).

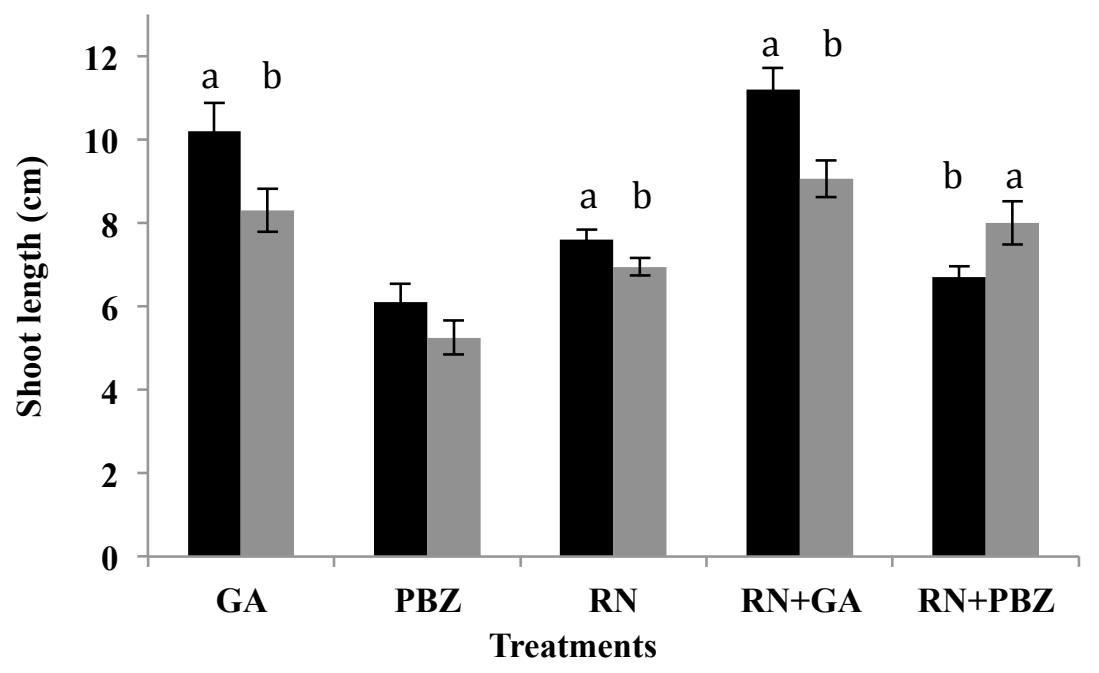

Figure 58: Influence of the treatment time to the entire tree on the final length of the shoot developed from the terminal bud of the vegetative panicle. Treatments performed in anthesis $11 / 04 / 2016$ (phenological state $610 \mathrm{BBCH}$ scale) (black bars) and at the time of the fruit set 26/04/2016 (Ø 3mm, phenological state $711 \mathrm{BBCH}$ scale) (gray bars). GA= gibberellic acid (50 $\left.\mathrm{mg} \mathrm{l}^{-1}\right), \mathrm{PBZ}=$ paclobutrazol $\left(50 \mathrm{mg} \mathrm{l}^{-1}\right), \mathrm{RN}=$ Ringing. Each value is the average of 10 shoots. The vertical bars indicate the standard error. Different letters for a same treatment indicate significant differences $(\mathrm{P} \leq 0.05)$.

It is worth noting that, also in this case, our results suggest that the fruit set is not influenced by the growth of the shoot of the terminal bud of the panicle. So, for example, approximately 15 days after treatment, when the number of fruits per panicle in the control trees and treated with GA was the same, 10 fruits (Figure 54 A), the shoot of the second measured double the first (Figure 57 A). Therefore, the fruit set of avocado does not seem to be regulated by competition phenomena for the development.

\subsubsection{On the carbohydrate content}

The GA applied to individual panicles promoted the synthesis of transport sugars in the leaves of the shoot from the terminal bud, at the same time that it significantly reduced the concentration of sugars consumption (Figure 59). This effect is consistent with the greater growth of shoots obtained by action of this substance (see Figure 55). The decrease in the concentration of glucose-6-P in the 
leaves treated with GA (Figure 59) ratifies the stimulus on the vegetative development.

The PBZ, on the contrary, did not alter the balance of carbohydrates in the leaves. Both the concentration of transport sugars and the reducers was almost equal to that of the control trees (Figure 59). This is consistent with the results obtained in the growth of the shoots, as both presented an identical growth until mid-June (Figure 55), i.e. during the period of fruit set. Similar behaviour in the content of glucose-6-P between both treatments, PBZ and control, indicates that both sheets presented a similar metabolic activity despite the fact that the PBZ anticipated significantly the abscission of flowers.

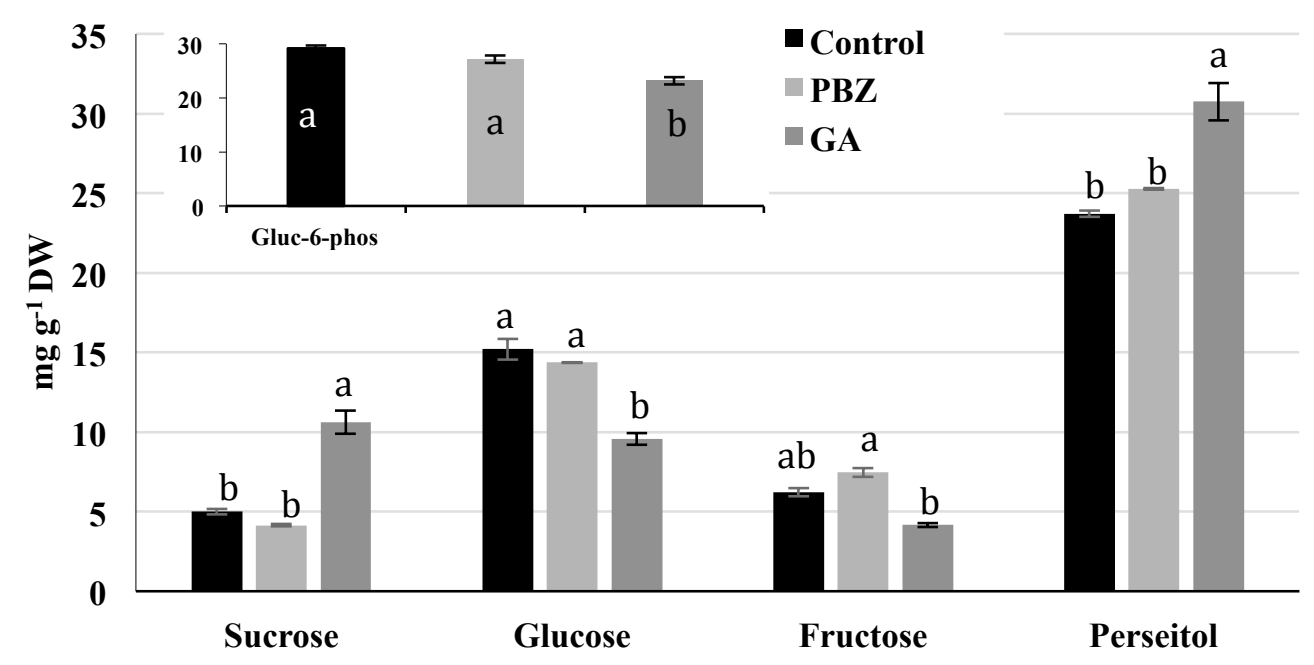

Figure 59: Influence of the application of inhibitors (PBZ $50 \mathrm{mg}^{-1}$ ) and promoters (GA $50 \mathrm{mg}^{-1}$ ) of development to individual inflorescences in the concentration of carbohydrates in the leaves $\mathrm{cv}$. Hass avocado. The application was carried out in the state $610 \mathrm{BBCH}$, when $10 \%$ of the flowers were open. Each point is the average of 10 thyrsi. The vertical bars indicate the standard error. Different letters for a same date indicate significant differences $(\mathrm{P} \leq 0.05)$. PBZ: paclobutrazol, GA: gibberellic acid. Date of treatments: April 9, 2015. Date of samples: July 13, 2015. State 719 $\mathrm{BBCH}$.

\subsection{Influence of Ringing, GA and PBZ on carbohydrate metabolism}

\subsubsection{Treatment on individual inflorescences}

\subsubsection{During flowering}

The treatments with GA and PBZ to individual inflorescences altered the metabolism of carbohydrates in flowers drops. Thus, approximately 15 days after the treatment (April 23), flowers drops had a content of G-6-P significantly higher in the trees treated with GA $\left(5.88 \mathrm{mg} \mathrm{g}^{-1} \mathrm{DW}\right)$ than in the rest of the treatments 
(3.52 and $3.52 \mathrm{mg} \mathrm{g}^{-1} \mathrm{DW}$ for the control and PBZ, respectively) (Figure 60). In all cases, however, its concentration diminished with time. This sugar is an indicator of the cellular metabolic activity and its decline with the time indicates that it is gradually increased, as corresponds to the process of fruit set.

\section{BBCH}

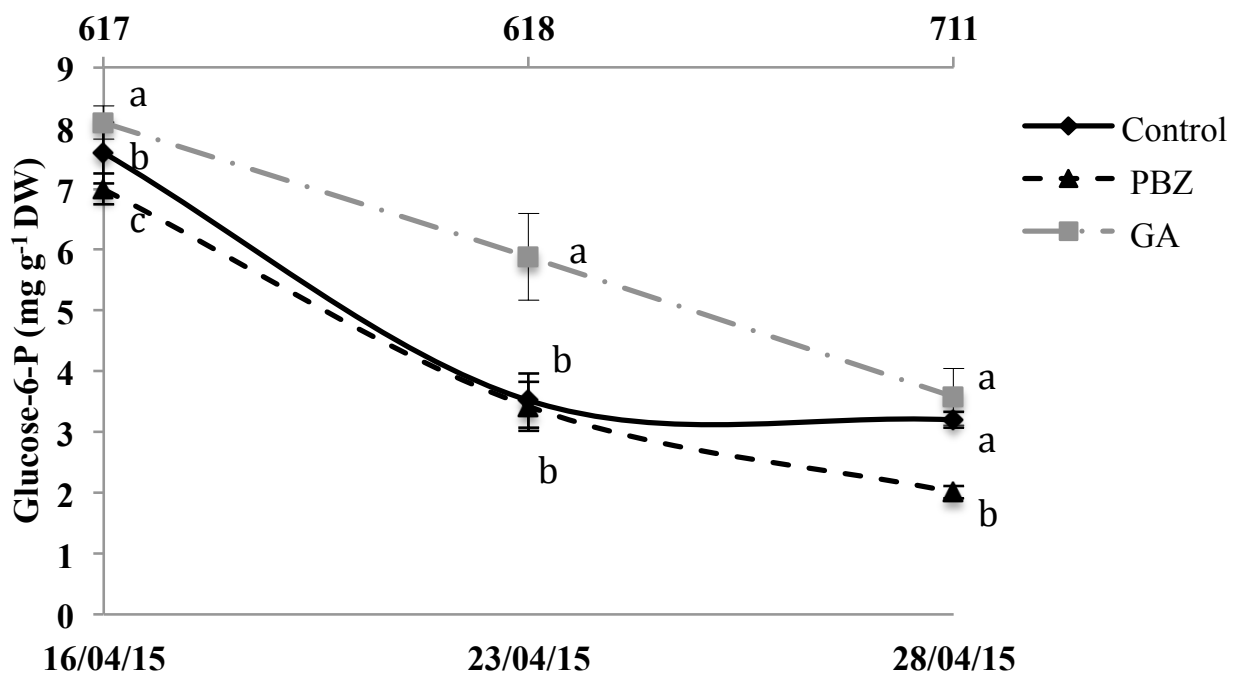

Figure 60: Influence of the application of inhibitors (PBZ $50 \mathrm{mg}^{-1}$ ) and promoters (GA $50 \mathrm{mg}^{-1}$ ) of development to individual inflorescences in the concentration of glucose-6-P of flowers drops of avocado cv. Hass. The application was made to individual panicles in the phenological state 610 $\mathrm{BBCH}$ scale, when $10 \%$ of the flowers were open. Each value is the average of 10 thyrsi. The vertical bars indicate the standard error. Different letters for a same date indicate significant differences $(\mathrm{P} \leq 0.05)$. The upper shaft represents the phenological states according to the $\mathrm{BBCH}$ scale. PBZ: paclobutrazol; GA: gibberellic acid. Date of treatments: April 9, 2015.

The behaviour of the transport carbohydrates, sucrose and perseitol, was different. Although, in general, the highest content in both presented flowers drops of the treated branches with GA and the lowest of the treated with PBZ (Figures 61 and 62), the sucrose content increased with time during the whole period of the experiment, regardless of treatment, while the perseitol rose slightly during the two weeks following the same to descend below so more marked by the action of the PBZ (7.55 $\left.\mathrm{mg} \mathrm{g}^{-1} \mathrm{DW}\right)$ and almost imperceptibly into the flowers treated with GA (16.03 $\left.\mathrm{mg} \mathrm{g}^{-1} \mathrm{DW}\right)$, leaving the controls in an intermediate position (11.68 $\mathrm{mg}$ $\mathrm{g}^{-1} \mathrm{DW}$ ) (Figures 61 and 62).

The behaviour of transport sugars, mainly sucrose, is logical since it coincides with two sink effects that occur at the same time, the flowering and the first sprouting. 


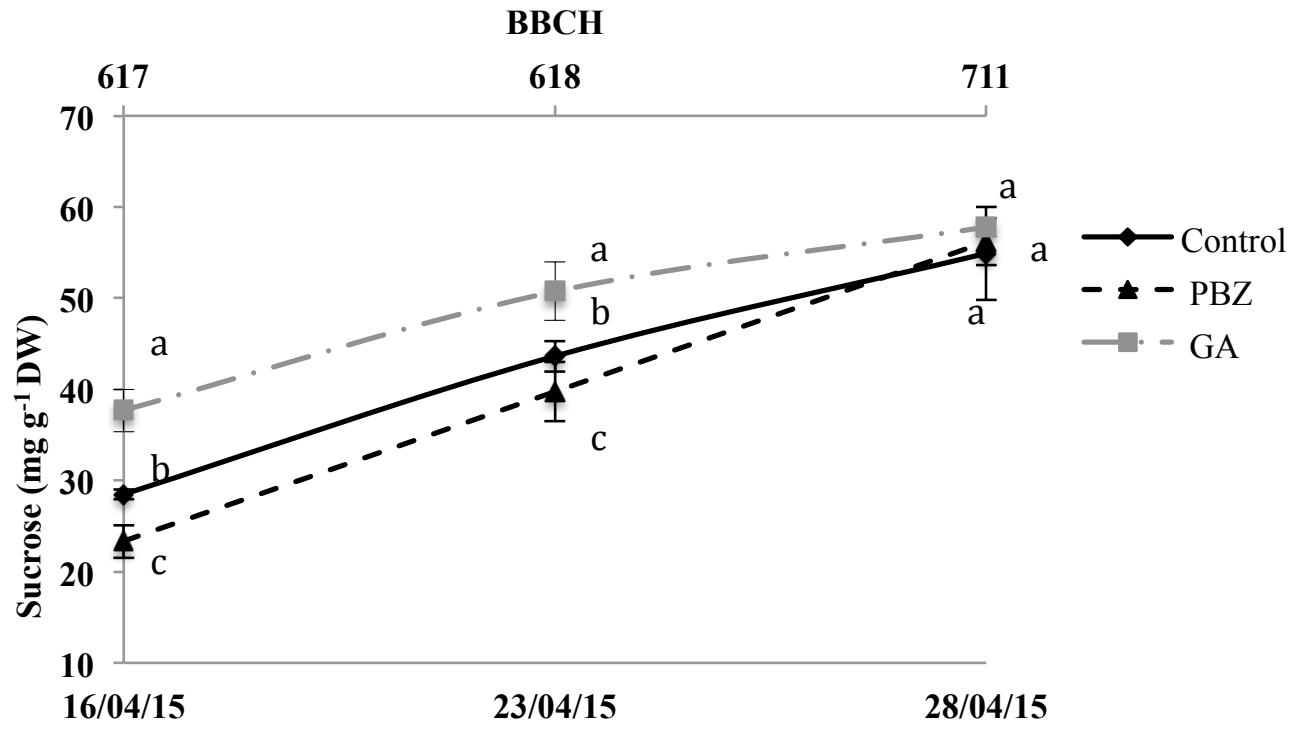

Figure 61: Influence of the application of inhibitors (PBZ $50 \mathrm{mg}^{-1}$ ) and promoters (GA $50 \mathrm{mg}^{-1}$ ) of development to individual inflorescences in the concentration of sucrose of flowers drops of avocado cv. Hass. The application was made to individual panicles in the phenological state 610 $\mathrm{BBCH}$ scale, when $10 \%$ of the flowers were open. Each value is the average of 10 thyrsi. The vertical bars indicate the standard error. Different letters for a same date indicate significant differences $(\mathrm{P} \leq 0.05)$. The upper shaft represents the phenological states according to the $\mathrm{BBCH}$ scale. PBZ: paclobutrazol; GA: gibberellic acid. Date of treatments: April 9, 2015.

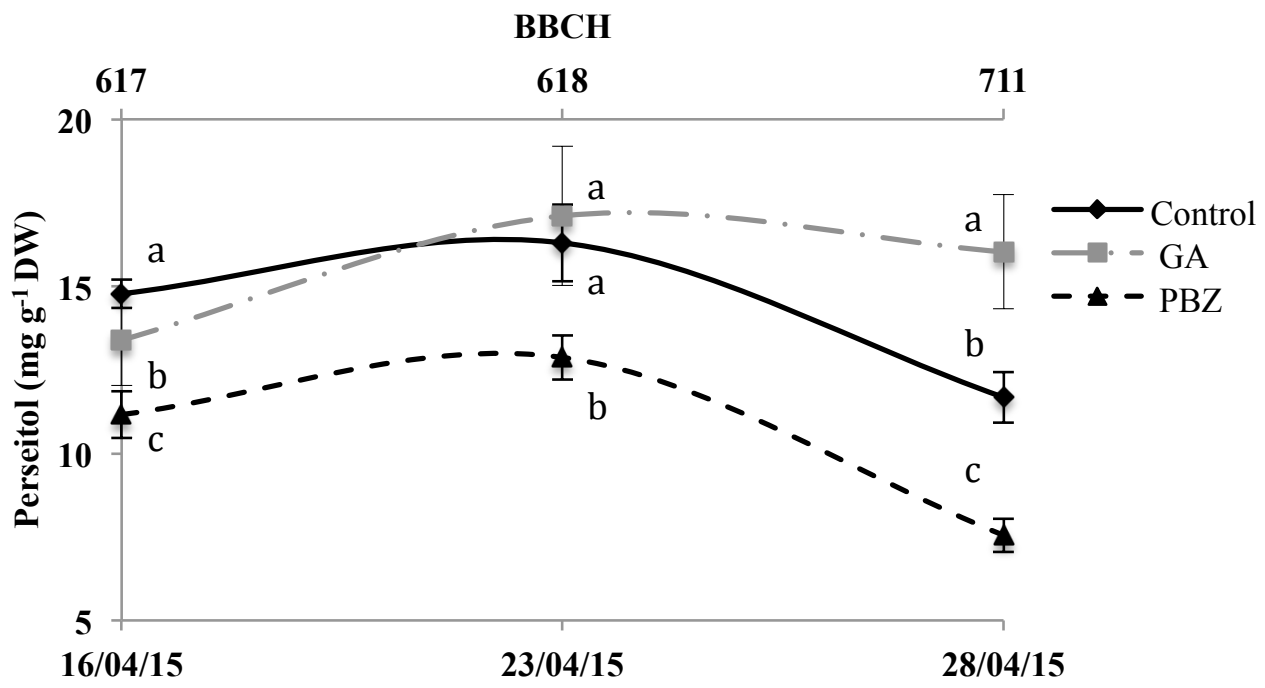

Figure 62: Influence of the application of inhibitors (PBZ $50 \mathrm{mg} \mathrm{l}^{-1}$ ) and promoters (GA $50 \mathrm{mg} \mathrm{l}^{-1}$ ) of development to individual inflorescences in the concentration of perseitol of flowers drops of avocado cv. Hass. The application was made to individual panicles in the phenological state 610 $\mathrm{BBCH}$ scale, when $10 \%$ of the flowers were open. Each value is the average of 10 thyrsi. The vertical bars indicate the standard error. Different letters for a same date indicate significant differences $(\mathrm{P} \leq 0.05)$. The upper shaft represents the phenological states according to the $\mathrm{BBCH}$ scale. PBZ: paclobutrazol; GA: gibberellic acid. Date of treatments: April 9, 2015.

The concentration of glucose of flowers drop decreased with the time to reach the lowest values at the time of the fruit set (Figure 63). At this time the flowers of the 
control trees showed the highest concentration $\left(32.1 \mathrm{mg} \mathrm{g}^{-1} \mathrm{DW}\right)$ and the flowers of the treated trees showed the lowest (27 mg g$\left.{ }^{-1} \mathrm{DW}\right)$. It should be noted that the concentration of glucose from the flowers of treated branches with PBZ was the lowest since the week after the treatments $\left(32.84 \mathrm{mg} \mathrm{g}^{-1} \mathrm{DW}\right.$ vs. $39 \mathrm{mg} \mathrm{g}^{-1} \mathrm{DW}$ for the other two) thus keeping up to the time of the fruit set in that is matched with the one treated with GA (Figure 63).

The fructose followed a similar trend, although with higher values for the whole period and for all treatments and with a behaviour of the treated flowers with PBZ similar to that of the rest of the treatment, except for the first date of analysis (made a week after) (Figure 64). In this case the concentration at the time of the fruit set was the same for all the flowers.

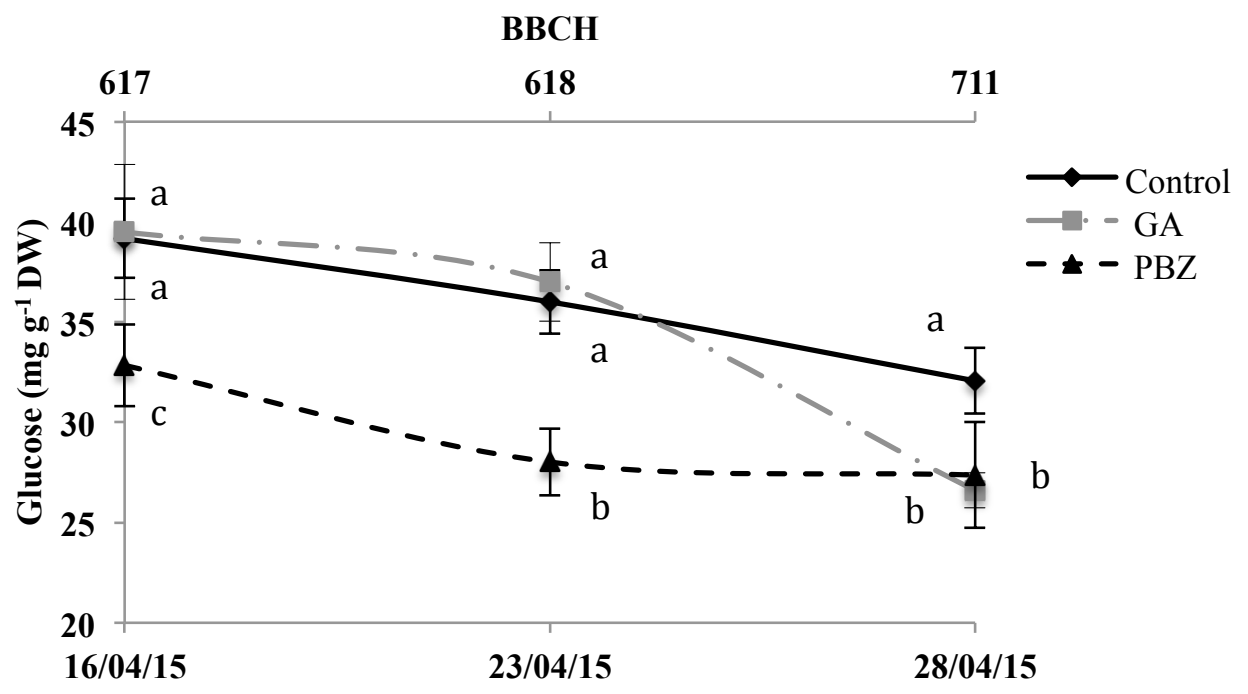

Figure 63: Influence of the application of inhibitors (PBZ $50 \mathrm{mg} \mathrm{l}^{-1}$ ) and promoters (GA $50 \mathrm{mg}^{-1}$ ) of development to individual inflorescences in the concentration of glucose of flowers drops of avocado cv. Hass. The application was made to individual panicles in the phenological state 610 $\mathrm{BBCH}$ scale, when $10 \%$ of the flowers were open. Each value is the average of 10 thyrsi. The vertical bars indicate the standard error. Different letters for a same date indicate significant differences $(\mathrm{P} \leq 0.05)$. The upper shaft represents the phenological states according to the $\mathrm{BBCH}$ scale. PBZ: paclobutrazol; GA: gibberellic acid. Date of treatments: April 9, 2015. 


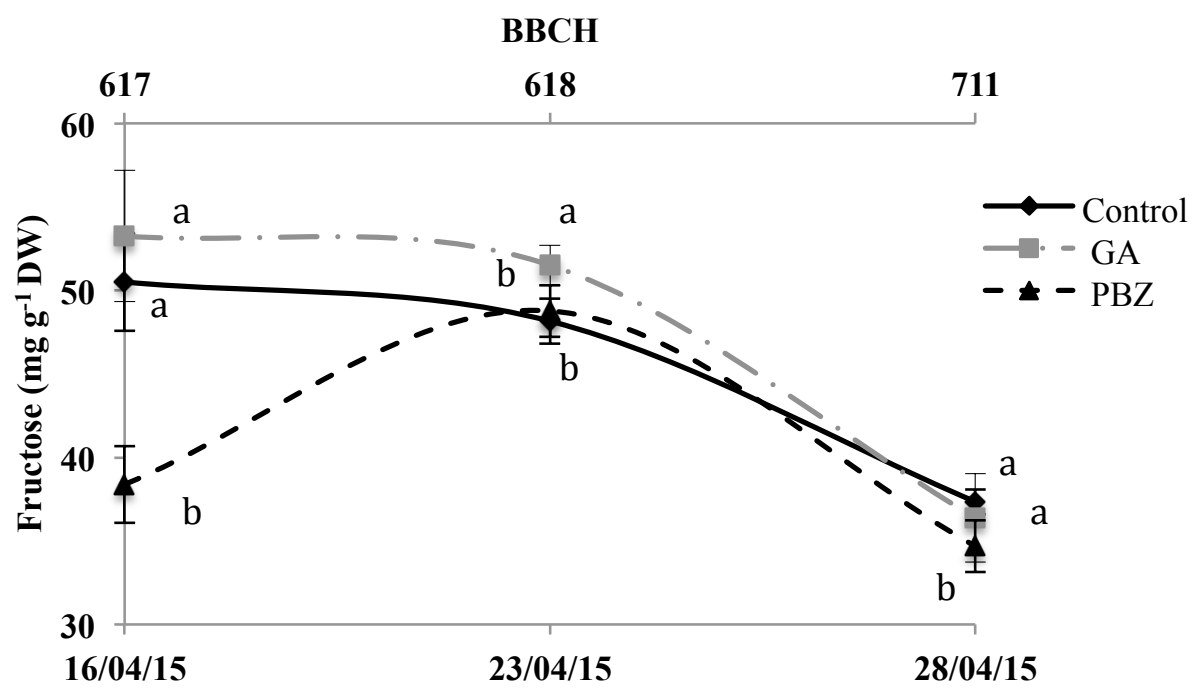

Figure 64: Influence of the application of inhibitors (PBZ $50 \mathrm{mg} \mathrm{l}^{-1}$ ) and promoters (GA $50 \mathrm{mg}^{-1}$ ) of development to individual inflorescences in the concentration of fructose of flowers drops of avocado cv. Hass. The application was made to individual panicles in the phenological state 610 $\mathrm{BBCH}$ scale, when $10 \%$ of the flowers were open. Each value is the average of 10 thyrsi. The vertical bars indicate the standard error. Different letters for a same date indicate significant differences $(\mathrm{P} \leq 0.05)$. The upper shaft represents the phenological states according to the $\mathrm{BBCH}$ scale. PBZ: paclobutrazol; GA: gibberellic acid. Date of treatments: April 9, 2015.

\subsubsection{During the initial development of fruit}

The carbohydrates balance was also altered in the fruit drop by action of the treatments to individual inflorescences, regardless of the time in which they were conducted. Thus, approximately a month after the treatment (May 4), the fruit drops had a content of g-6-P significantly higher in the trees treated with GA $\left(6.93 \mathrm{mg} \mathrm{g}^{-1} \mathrm{DW}\right)$ than in the rest of the treatments $\left(5.84\right.$ and $4.55 \mathrm{mg} \mathrm{g}^{-1} \mathrm{DW}$ or those treated with PBZ and control, respectively) (Figure 65). At the end of the study period the differences between the control and PBZ disappeared, but the content in the fruits of inflorescences treated with GA was higher (5.75 vs. $2.2 \mathrm{mg}$ $\mathrm{g}^{-1} \mathrm{DW}$ of the other two treatments) (Figure 65). The downward trend of the glucose-6-phosphate with the time, between the phenological states 712 to 715 of the $\mathrm{BBCH}$ scale, was more pronounced in the fruit drop of the panicles treated with PBZ and control than in those treated with GA. 
BBCH

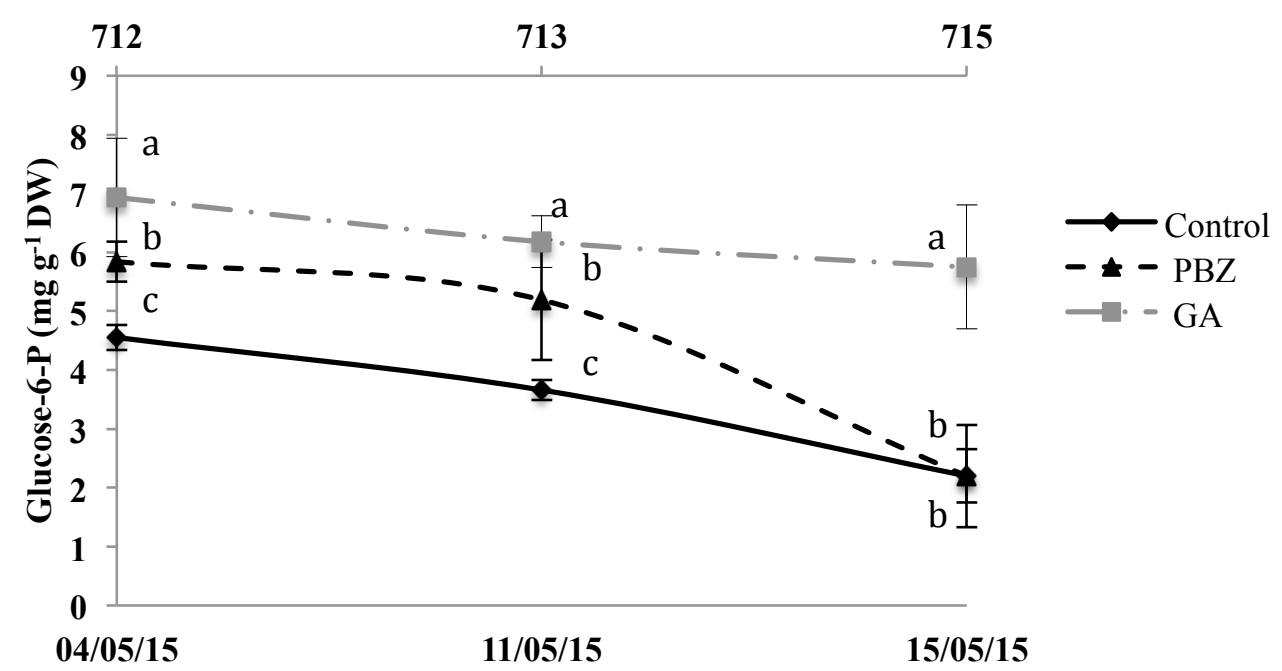

Figure 65: Influence of the application of inhibitors (PBZ $50 \mathrm{mg}^{-1}$ ) and promoters (GA $50 \mathrm{mg}^{-1}$ ) of development to individual inflorescences in the concentration of glucose-6-P of fruits drops of avocado cv. Hass. The application was made to individual panicles in the phenological state 610 $\mathrm{BBCH}$ scale, when $10 \%$ of the flowers were open. Each value is the average of 10 thyrsi. The vertical bars indicate the standard error. Different letters for a same date indicate significant differences $(\mathrm{P} \leq 0.05)$. The upper shaft represents the phenological states according to the $\mathrm{BBCH}$ scale. PBZ: paclobutrazol; GA: gibberellic acid. Date of treatments: April 9, 2015.

The behaviour of the transport carbs was also in this case, different. The fruits set of the panicles treated with GA had the highest content of sucrose and perseitol.

In general the sucrose content decreased during the early development stages to after increase between the phenological states 713 and 715 the $\mathrm{BBCH}$ scale (Figure 66). In particular during the first phases (phenological states 712 and 715 , respectively), the fruit drop of panicles treated with GA had a greater concentration of sucrose ( 8.33 and $4.96 \mathrm{mg} \mathrm{g}^{-1} \mathrm{DW}$ ), while in the last studied phase (status $715 \mathrm{BBCH}$ ) the fruit drop from panicles treated with PBZ reached the highest values $\left(7.02 \mathrm{mg} \mathrm{g}^{-1} \mathrm{DW}\right)$. The concentration of the fruits of the panicles control is always maintained lower. 


\section{ВBCH}

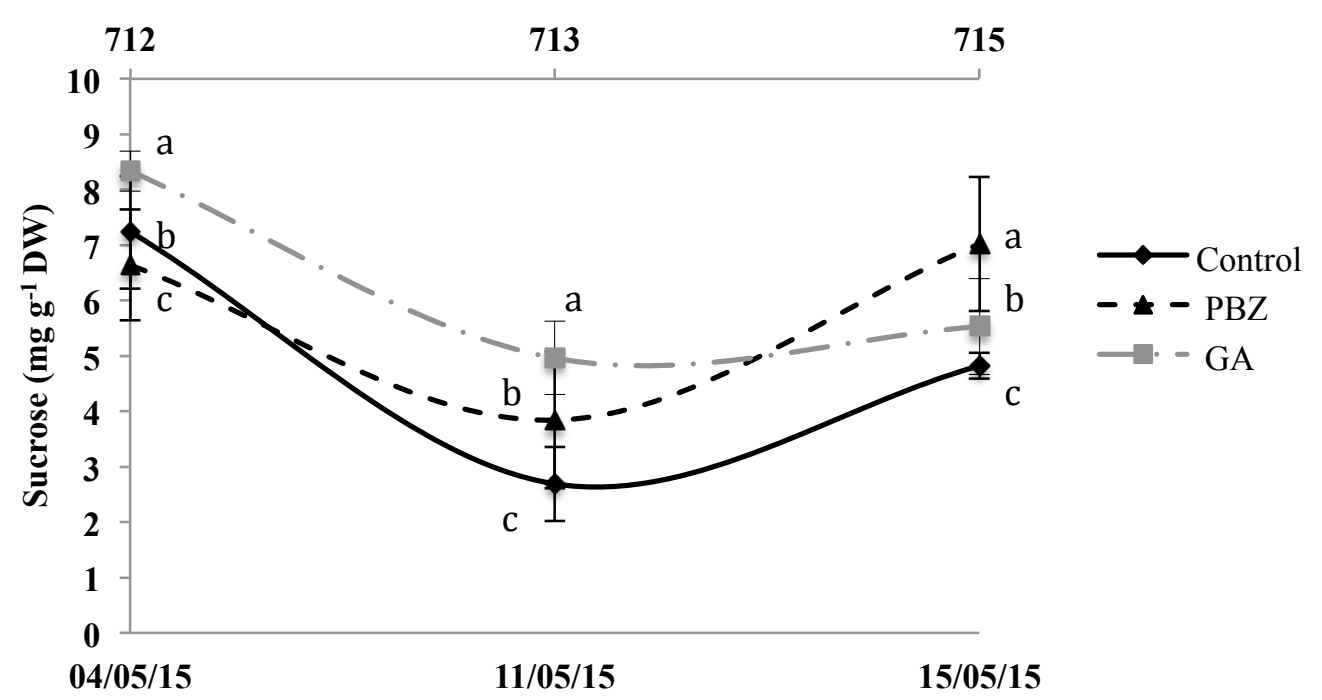

Figure 66: Influence of the application of inhibitors (PBZ $50 \mathrm{mg} \mathrm{l}^{-1}$ ) and promoters (GA $50 \mathrm{mg}^{-1}$ ) of development to individual inflorescences in the concentration of sucrose of fruits drops of avocado cv. Hass. The application was made to individual panicles in the phenological state 610 $\mathrm{BBCH}$ scale, when $10 \%$ of the flowers were open. Each value is the average of 10 thyrsi. The vertical bars indicate the standard error. Different letters for a same date indicate significant differences $(\mathrm{P} \leq 0.05)$. The upper shaft represents the phenological states according to the $\mathrm{BBCH}$ scale. PBZ: paclobutrazol; GA: gibberellic acid. Date of treatments: April 9, 2015.

The concentration of perseitol of the fruit drop, by against, barely changed over time, showing the panicles treated with PBZ and control a slight tendency to decline in the last phenological state studied (state $715 \mathrm{BBCH}$ ) (Figure 67). However, the panicles treated with GA slightly increased the concentration over the study period reaching a maximum value of $13.6 \mathrm{mg} \mathrm{g}^{-1} \mathrm{DW}$ in the last phenological state studied. 
ВBCH

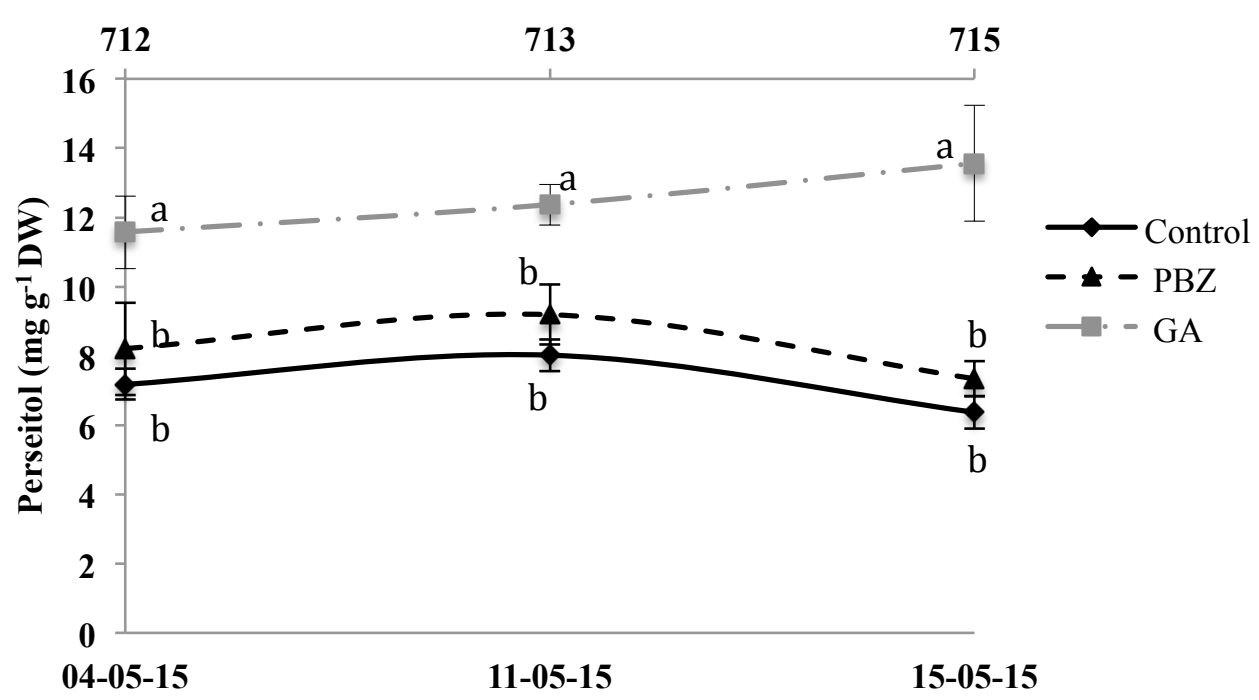

Figure 67: Influence of the application of inhibitors (PBZ $50 \mathrm{mg}^{-1}$ ) and promoters (GA $50 \mathrm{mg}^{-1}$ ) of development to individual inflorescences in the concentration of perseitol of fruits drops of avocado cv. Hass. The application was made to individual panicles in the phenological state 610 $\mathrm{BBCH}$ scale, when $10 \%$ of the flowers were open. Each value is the average of 10 thyrsi. The vertical bars indicate the standard error. Different letters for a same date indicate significant differences $(\mathrm{P} \leq 0.05)$. The upper shaft represents the phenological states according to the $\mathrm{BBCH}$ scale. PBZ: paclobutrazol; GA: gibberellic acid. Date of treatments: April 9, 2015.

The fruits drop showed a slight increase of the concentration of glucose during the 30 days after the treatment and a decline during the last phase of study, in particular in those treated with GA and PBZ that reached the lowest values in the phenological state 715 of the $\mathrm{BBCH}$ scale (12.3 and $9.5 \mathrm{mg} \mathrm{g}^{-1} \mathrm{DW}$, respectively) (Figure 68). The concentration of the fruit drop of panicles control remained almost constant during the whole period of study. 


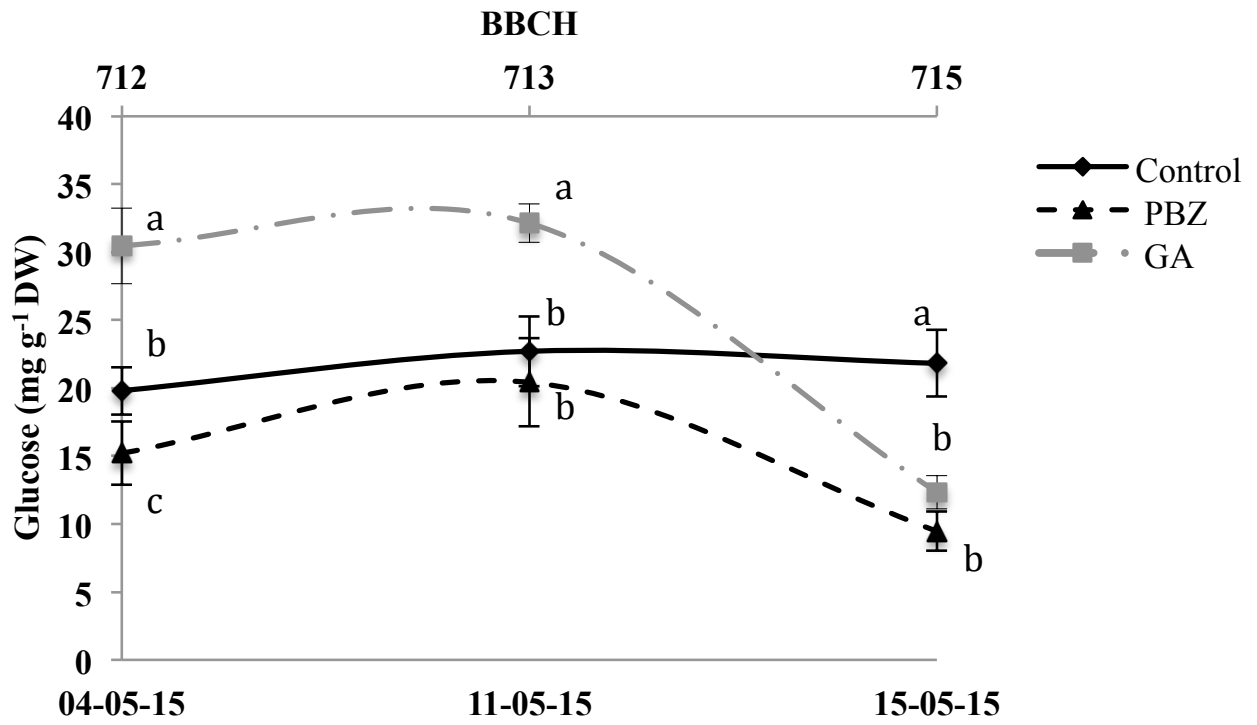

Figure 68: Influence of the application of inhibitors (PBZ $50 \mathrm{mg}^{-1}$ ) and promoters (GA $50 \mathrm{mg}^{-1}$ ) of development to individual inflorescences in the concentration of glucose of fruits drops of avocado cv. Hass. The application was made to individual panicles in the phenological state 610 $\mathrm{BBCH}$ scale, when $10 \%$ of the flowers were open. Each value is the average of 10 thyrsi. The vertical bars indicate the standard error. Different letters for a same date indicate significant differences $(\mathrm{P} \leq 0.05)$. The upper shaft represents the phenological states according to the $\mathrm{BBCH}$ scale. PBZ: paclobutrazol; GA: gibberellic acid. Date of treatments: April 9, 2015.

In regard to the fructose (Figure 69) the fruit drop showed a similar pattern in the different treatments. During the first days, the concentration remained more or less constant in the fruits of panicles treated with PBZ and of the control without showing significant differences between them. In the last analysis, the same concentration remained in the fruits of the panicles control $\left(21.5 \mathrm{mg} \mathrm{g}^{-1} \mathrm{DW}\right)$, and lower in those treated with PBZ (13.29 $\left.\mathrm{mg} \mathrm{g}^{-1} \mathrm{DW}\right)$. The fruits of the panicles treated with GA showed a slight increase in the first week of evaluation, after remaining stable until the last date of the analysis, when they reached the highest value of all treatments $\left(25.7 \mathrm{mg} \mathrm{g}^{-1} \mathrm{DW}\right.$ ) (Figure 69). 
BBCH

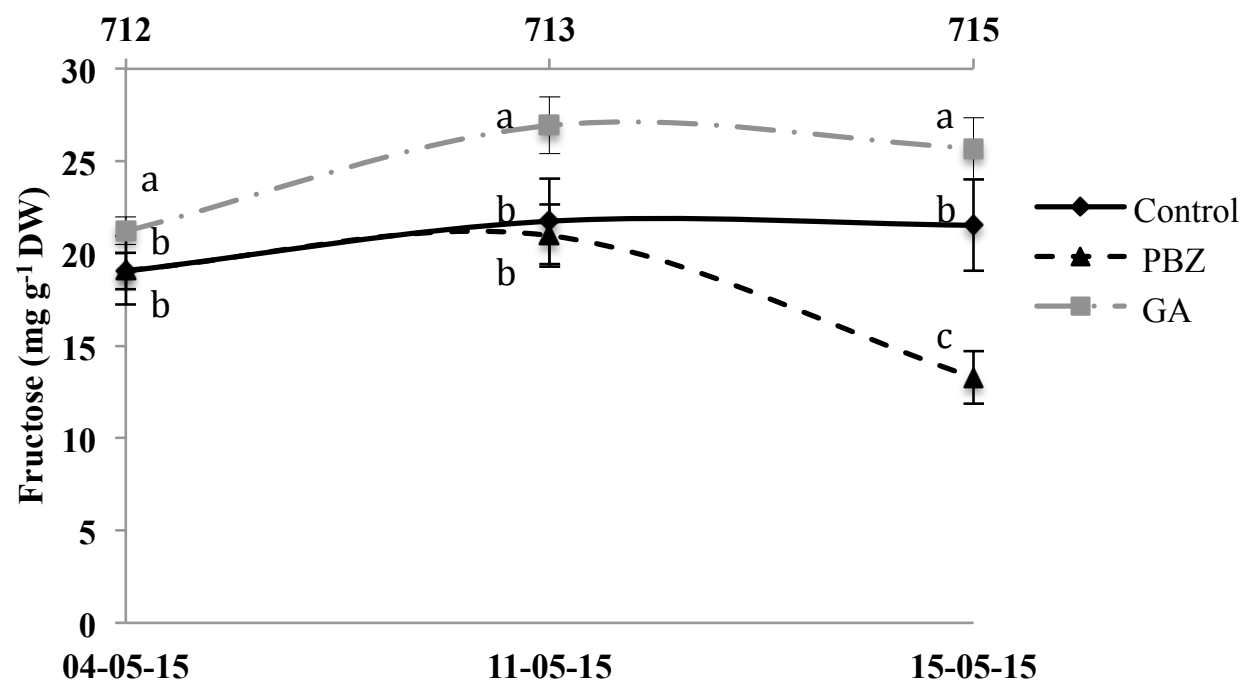

Figure 69: Influence of the application of inhibitors (PBZ $50 \mathrm{mg} \mathrm{l}^{-1}$ ) and promoters (GA $50 \mathrm{mg}^{-1}$ ) of development to individual inflorescences in the concentration of fructose of fruits drops of avocado cv. Hass. The application was made to individual panicles in the phenological state 610 $\mathrm{BBCH}$ scale, when $10 \%$ of the flowers were open. Each value is the average of 10 thyrsi. The vertical bars indicate the standard error. Different letters for a same date indicate significant differences $(\mathrm{P} \leq 0.05)$. The upper shaft represents the phenological states according to the $\mathrm{BBCH}$ scale. PBZ: paclobutrazol; GA: gibberellic acid. Date of treatments: April 9, 2015.

\subsubsection{Treatments to the entire tree}

The balance of carbohydrates in the fruits set was also altered by the treatments made to the entire tree, regardless of the time in which they were made. Thus, approximately 15 days after the treatment (April 25), the fruits set had a significantly higher glucose content in the control trees $\left(32 \mathrm{mg} \mathrm{g}^{-1} \mathrm{DW}\right)$ than in the rest of the treatments $\left(23,12\right.$ y $6 \mathrm{mg} \mathrm{g}^{-1} \mathrm{DW}$ for those treated with GA, ringing and treated with PBZ, respectively) (Figure $70 \mathrm{~A}$ ). This effect, however, was offset by the ringing, so that its combination with the application of GA or PBZ increased the glucose content of the fruits of trees treated to similar concentrations with control and did not statistically differ between them (Figure $70 \mathrm{~A})$.

A double factorial analysis of the GA effect and ringing indicates that the comparison between the content of the fruits of trees control and treated with GA and PBZ, the latter as an inhibitor of the synthesis of gibberellins, shows no statistically significant differences between their average, while the effect of ringing, yes $(P \leq 0.01)$. But what is really important is that the interaction GA $\mathrm{x}$ ringing reached statistical significance $(P \leq 0.01)$, indicating that the effect of the 
GA is mediated by ringing. What is more, the application of GA also improved the effect of ringing by itself. The statistically significant interaction of GA $x$ date and ringing $x$ date is logical because the values of glucose is altered over time, but lacks importance in itself, except that derived from the comparative performance between treatments, which is further analysed below.

On the contrary, in the fructose content no significant differences were found between the control and the GA (Figure $70 \mathrm{~B}$ ) and the application of AG or PBZ to previously ringing trees decreased and increased, respectively, its concentration with respect to the control (Figure $70 \mathrm{~A}$ and $\mathrm{B}$ ). Also in this case, the interaction GA $x$ ringing reached statistical significance, in a similar manner to what happened with the glucose.

The behaviour of the carbs of transport was not very different. In this case, although most of the sucrose content and perseitol owned by the fruits set of control and treated with GA, 63 and $10 \mathrm{mg} \mathrm{g}^{-1} \mathrm{DW}$ and 74 and $18 \mathrm{mg} \mathrm{g}^{-1} \mathrm{DW}$, respectively, the order was reversed and those treated the second, i.e., with GA, presented a higher content of both carbohydrates in respect of the first (Figure 70 $\mathrm{C}$ and $\mathrm{D})$. The combination of treatments decreased the sucrose content, and increased the perseitol regarding the control in a $60 \%$ and $30 \%$ for ringing + GA and ringing $+\mathrm{PBZ}$, respectively. In both cases, only the GA factor was statistically significant $(P \leq 0.01)$, also achieving the interaction $A G \times$ scratched the significance $(\mathrm{P} \leq 0.01)$, explaning thus the lower and higher sucrose content and perseitol, respectively, in the fruits of the treated trees and ringing at a time (Figure $70 \mathrm{C}$ and D).

It is important to highlight that, in general terms, the treatments that 15 days after they obtained a greater number of fruit sets, this is the control and the GA (10 fruits per panicle, on average) (see figure 54), obtained a higher content of sugars consumption and transport, except the ringing that presented an intermediate behaviour. In line with this, the PBZ was the treatment that got a smaller number of fruit sets (5.8 fruits per panicle) and a lower concentration of sugars consumption and transport, and the combination of ringing + GA the largest number of fruits (up to 9 fruits $\neq$ more per panicle), and the largest concentration of carbohydrates (Figure $54 \mathrm{~A}$ and Figure 70). 

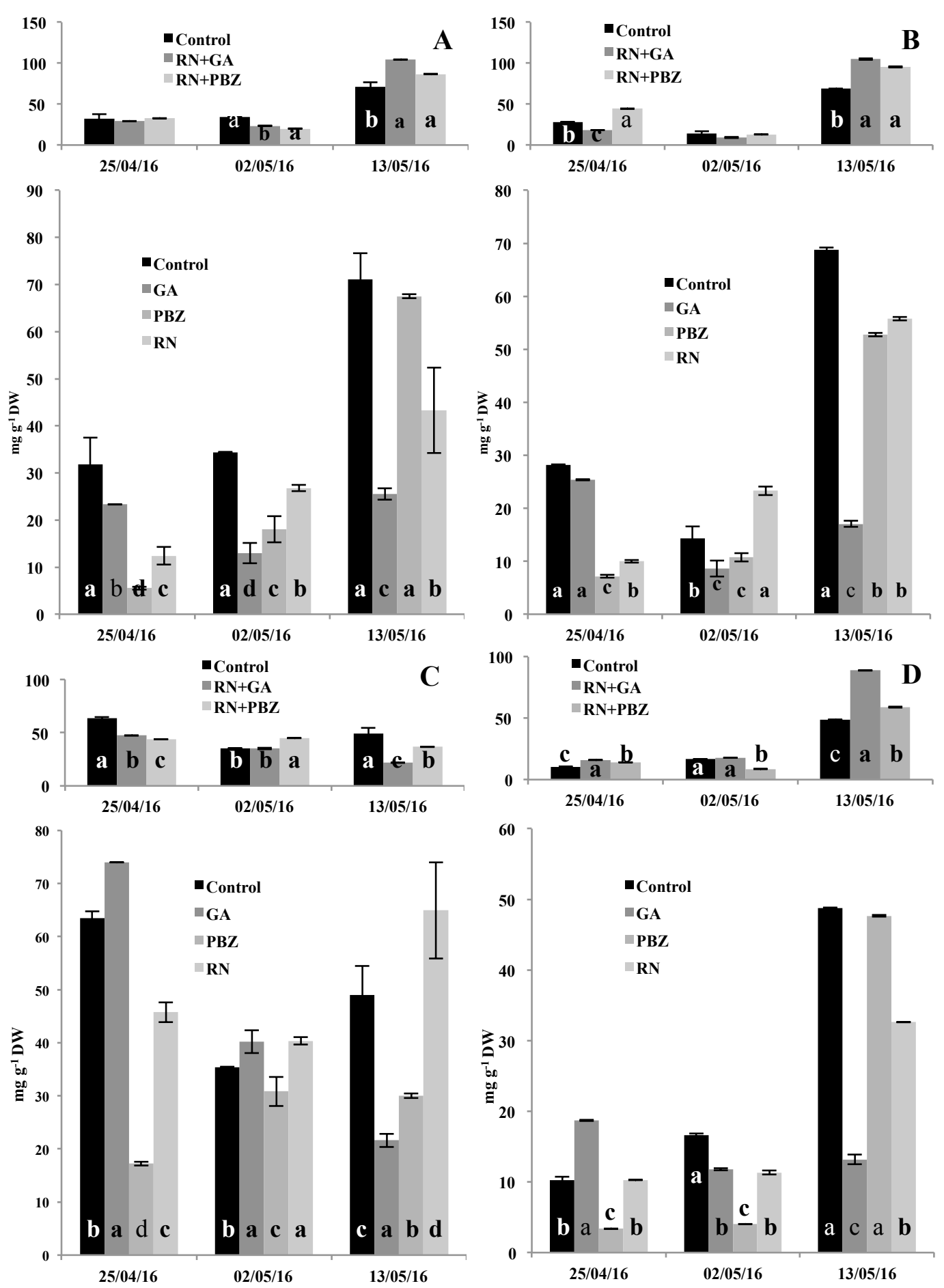

Figure 70: Influence of ringing and the application of GA $\left(50 \mathrm{mg}^{-1}\right)$ and PBZ $\left(50 \mathrm{mg} \mathrm{l}^{-1}\right)$ in anthesis (phenological state $610 \mathrm{BBCH}$ scale) to entire the tree of the glucose content (A), fructose (B), sucrose (C) and perseitol (D) in fruit sets of cv. Hass avocado. Each value is the average of 4 samples. Treatment Date: 11/04/2016. The vertical bars indicate the standard error. GA: gibberellic acid; PBZ: Paclobutrazol; RN: Ringing. Different letters for a same date indicate significant differences $(P \leq 0.05)$. DW $=$ dry weight of the samples. 
A week later (May 2), while the control maintained the concentration of glucose stable (34 $\mathrm{mg} \mathrm{g}^{-1} \mathrm{DW}$ ) the fruits of trees treated with GA fell by $52 \%$, while those treated with PBZ and ringing increased by $241 \%$ and $89 \%$, respectively (Figure 70 A). A similar behaviour between treatments occurred with the fructose, although in this case the control decreased its content in a 50\% compared to the previous date (Figure $70 \mathrm{~B}$ ). In any case, the combination of treatments improved the response with respect to the control, although it was slowly, but erratically, in respect of individual treatment (Figure $70 \mathrm{~A}$ and B). For example, while the concentration of glucose in the fruits treated with GA was $13 \mathrm{mg} \mathrm{g}^{-1} \mathrm{DW}$, the combination of the latter with the ringing improved up to $23 \mathrm{mg} \mathrm{g}^{-1} \mathrm{DW}$ (Figure $70 \mathrm{~A})$.

The trend of the sugars of transport, on the contrary, scarcely changed and in this week (May 2), the fruits of trees treated with GA or ringing remained with the highest content of sucrose and perseitol, closely followed by the control trees, being treated with PBZ those that had the lowest concentration (Figure $70 \mathrm{C}$ and D). It is however noted a quantitative difference with the passage of time, as evidenced by the interaction with the above mentioned dates of analysis, especially in the sucrose content that in the fruits of the control trees and in those treated with GA were reduced to $45 \%$ and $46 \%$, respectively, while in the trees treated with PBZ increased by $88 \%$ (Figure $70 \mathrm{C}$ ).

It is important to emphasize that the decline in the number of fruits per panicle found on this date for the ringing, up to 7 fruits less with regard to the control (Figure $54 \mathrm{~A}$ ), coincided with the widespread increase in the concentration of sugars consumption (Figure 70). However, the number of fruits set in the PBZ was significantly lower (up to 2 fruits less than the ringing), and also what was significant the carbohydrate content of consumption (4 and $13 \mathrm{mg} \mathrm{g}^{-1} \mathrm{DW}$ less of glucose and fructose, respectively) and transport (10 and $7 \mathrm{mg} \mathrm{g}^{-1} \mathrm{DW}$ of sucrose and perseitol, respectively) concerning the ringing. These differences persisted over time and 30 days after treatment (May 13) still significant differences were found in the content of carbohydrates in the fruit sets of different treatments. The highest content of glucose recorded the control fruits $\left(70 \mathrm{mg} \mathrm{g}^{-1} \mathrm{DW}\right)$ and the PBZ (67 $\left.\mathrm{mg} \mathrm{g}^{-1} \mathrm{DW}\right)$, followed by the ringing (43 $\left.\mathrm{mg} \mathrm{g}^{-1} \mathrm{DW}\right)$ and GA $\left(25 \mathrm{mg} \mathrm{g}^{-1} \mathrm{DW}\right)$ 
(Figure $70 \mathrm{~A}$ ). In the case of fructose, the control fruits also that had the greatest concentration, with values similar to those of the glucose $\left(68 \mathrm{mg} \mathrm{g}^{-1} \mathrm{DW}\right)$, followed by those of the ringing trees $\left(55 \mathrm{mg} \mathrm{g}^{-1} \mathrm{DW}\right)$ and treated with PBZ (52 $\mathrm{mg} \mathrm{g}^{-1} \mathrm{DW}$ ), without significant differences between them but yes with the fruits of the control trees, and they are fruits of trees treated with GA which recorded, as in the case of glucose, the lowest concentration $\left(17 \mathrm{mg} \mathrm{g}^{-1} \mathrm{DW}\right.$ ) (Figure $\left.70 \mathrm{~B}\right)$. On this date, unlike what can be observed in the previous two, the combination of treatments, ringing $+\mathrm{GA}$ and ringing $+\mathrm{PBZ}$, improved the concentration of both carbohydrates. Thus, the concentration of glucose in the fruits increased compared to control, $30 \mathrm{mg} \mathrm{g}^{-1} \mathrm{DW}$ in ringing $+\mathrm{GA}$, and $20 \mathrm{mg} \mathrm{g}^{-1} \mathrm{DW}$ in ringing $+\mathrm{PBZ}$. The fructose did so in the same proportion, approximately (Figure $70 \mathrm{~A}$ and $\mathrm{B}$ ).

It is to be noted that, with the exception of the GA, the highest content of carbohydrates, was recorded in this date (May 13), arriving to be in some cases, as in the case of the glucose, of more than double ( 2.3 times) than in the previous dates. Minors contents of glucose and fructose in that date in the fruits of trees treated with GA are correlated with the largest number of them in their panicles (Figure $54 \mathrm{~A}$ ). The balance of transport carbohydrates was also altered by the treatments on this date. While the higher sucrose content was found in the fruit sets of trees ringing $(33 \%, 108 \%$ and $154 \%$ more than in the control, PBZ and GA, respectively), perseitol was reached in the fruits of the control trees and treated with PBZ indiscriminately, with average values of $48 \mathrm{mg} \mathrm{g}^{-1} \mathrm{DW}$ and being a $184 \%$ and $60 \%$ higher than those treated with GA or ringing, respectively (Figure $70 \mathrm{C}$ and D). Only in the case of perseitol it succeeded to increase its contents with the combination of the treatments with respect to the control in 40 $\mathrm{mg} \mathrm{g}^{-1} \mathrm{DW}$ and $10 \mathrm{mg} \mathrm{g}^{-1} \mathrm{DW}$ for the ringing $+\mathrm{GA}$ and ringing $+\mathrm{PBZ}$, respectively.

Particularly interesting is the progressive decline over time and the lowest value in the sucrose content of the fruits treated with GA, alone or in combination with the ringing, compared to the rest of treatments (Figure $70 \mathrm{C}$ ), since it is also this case that correlates with the largest number of developing fruits (Figure 54).

The balance of carbohydrates from shoot originated from the terminal bud of the panicle was also altered by the treatments made at the time of anthesis. 
Thus, 15 days after the treatment (April 25), the shoots of the trees ringing together with those of the trees treated with GA, had more glucose $\left(12 \mathrm{mg} \mathrm{g}^{-1} \mathrm{DW}\right.$ and $11.76 \mathrm{mg} \mathrm{g}^{-1} \mathrm{DW}$, respectively) and fructose $\left(6 \mathrm{mg} \mathrm{g}^{-1} \mathrm{DW}\right.$ and $11.76 \mathrm{mg} \mathrm{g}^{-1}$ DW respectively), than the rest of the treatments (Figure $71 \mathrm{~A}$ and $\mathrm{B}$ ).

The shoots of the trees treated with PBZ were those who had lower content, occupying the controls an intermediate position.

However, in relation to the transport sugars (sucrose and perseitol), the fruits of trees ringing showed a lower content $\left(45 \mathrm{mg} \mathrm{g}^{-1} \mathrm{DW}\right)$ of sucrose than those treated with GA or PBZ (67 $\mathrm{mg} \mathrm{g}^{-1} \mathrm{DW}$ and $61 \mathrm{mg} \mathrm{g}^{-1} \mathrm{DW}$ respectively), and a similar content of perseitol in fruits of trees ringing or treated with PBZ (12.8 and 12.1 $\mathrm{mg} \mathrm{g}^{-1} \mathrm{DW}$, respectively) (Figure $71 \mathrm{C}$ and D). In this case the GA effect, understood as discussed in this study, did not reach statistical significance, but its interaction with ringing. What is more, the content of all sugars in the leaves of the branches ringing remained virtually constant, and even increased in some of them, over time (Figure 71), highlighting its interactive effect with the treatments. 


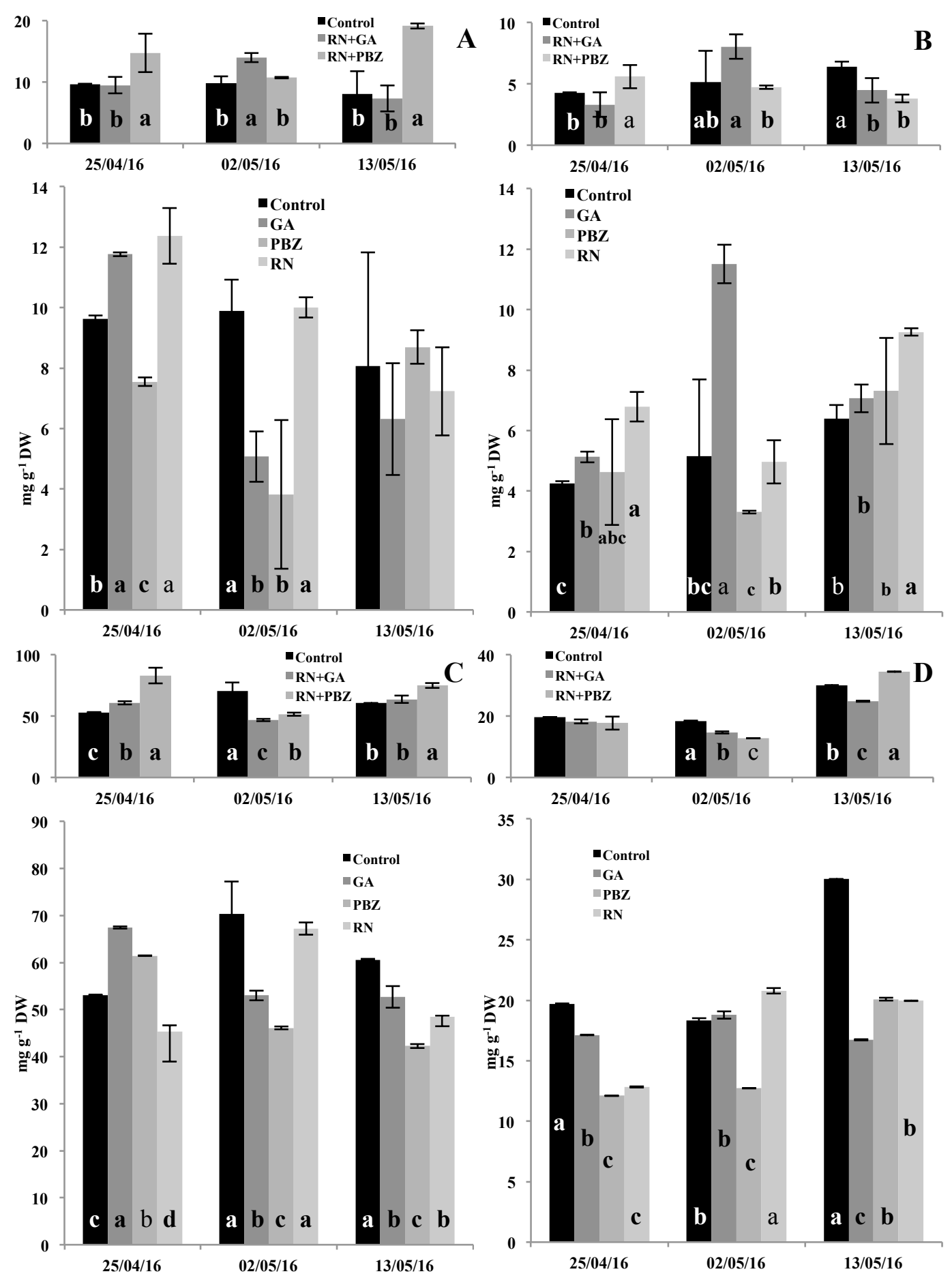

Figure 71: Influence of ringing and the application of GA $\left(50 \mathrm{mg} \mathrm{l}^{-1}\right)$ and PBZ $\left(50 \mathrm{mg} \mathrm{l}^{-1}\right)$ in anthesis (phenological state $610 \mathrm{BBCH}$ scale) to the entire tree of the glucose content (A), fructose (B), sucrose (C) and perseitol (D) in shoots developed from the terminal bud panicle of cv. Hass avocado. Each value is the average of 4 samples. Treatment Date: 11/04/2016. The vertical bars indicate the standard error. GA: gibberellic acid; PBZ: Paclobutrazol; RN: Ringing. Different letters for a same date indicate significant differences $(P \leq 0.05)$. DW $=$ dry weight of the samples.

A week later (May 2), shoots of the control trees had just changed their sugar content, with the exception of the sucrose (Figure 71). In the trees treated with 
GA, however, the glucose content of their shoots had decreased by $6 \mathrm{mg} \mathrm{g}^{-1} \mathrm{DW}$ while the fructose had increased by $6 \mathrm{mg} \mathrm{g}^{-1} \mathrm{DW}$. In the trees treated with PBZ the content of glucose, fructose and sucrose from their shoots had decreased and the combination GA + ringing had a positive effect on the glucose and fructose, increasing its content in 4 and $3 \mathrm{mg} \mathrm{g}^{-1} \mathrm{DW}$, respectively (Figure $71 \mathrm{~A}$ and $\mathrm{B}$ ), and negative for the sugars of transport (Figure $71 \mathrm{~B}$ and $\mathrm{C}$ ).

Approximately a month after the treatment (May 13), the concentration of glucose from the shoots of control trees and ringing decreased, while that of those treated with GA and PBZ increased, reaching values of 6.31 and $8.69 \mathrm{mg} \mathrm{g}^{-1} \mathrm{DW}$, respectively. On this date the combination ringing + PBZ doubled the glucose content in respect of the control. The fructose content of shoots was only increased by the action of ringing, reaching $9.2 \mathrm{mg} \mathrm{g}^{-1} \mathrm{DW}$, this is $30 \%$ more than that of the control trees. The highest content of transport sugars was detected in the controls. While for sucrose the PBZ gave rise to minor content in shoots $(42.3$ $\mathrm{mg} \mathrm{g}^{-1} \mathrm{DW}$ ), for the perseitol the shoots of the trees treated with GA reflected the lowest value (16.73 $\mathrm{mg} \mathrm{g}^{-1} \mathrm{DW}$ ) (Figure $71 \mathrm{C}$ and D). The combination ringing + PBZ increased its content of both sugars. It should be noted that the concentration of sugars consumption (glucose and fructose) detected was less than the transport sugars (sucrose and perseitol) having the sucrose the lowest concentration.

The realization of the treatments 15 days after the anthesis, in full process of fruit set, when the fruits had a diameter of $3 \mathrm{~mm}$, also altered the metabolism of carbohydrates. After approximately 7 days of treatment (May 2), the fruits of the control trees had a significantly higher content of glucose $\left(35 \mathrm{mg} \mathrm{g}^{-1} \mathrm{DW}\right)$ than in the rest of treatments (which was on average $18.5 \mathrm{mg} \mathrm{g}^{-1} \mathrm{DW}$ ). In the case of fructose, on the contrary, the fruits of the control trees and ringing presented a significantly lower concentration (around $15 \mathrm{mg} \mathrm{g}^{-1} \mathrm{DW}$ ) than those treated with GA or PBZ, (20 and $34 \mathrm{mg} \mathrm{g}^{-1} \mathrm{DW}$, respectively) (Figure $72 \mathrm{~A}$ and $\mathrm{B}$ ). In the case of the transport sugars, the concentration of sucrose was significantly higher in the fruit sets of control and treated with GA (36 $\mathrm{mg} \mathrm{g}^{-1} \mathrm{DW}$, on average) than in those of the trees ringing or treated with PBZ (30 and $24 \mathrm{mg} \mathrm{g}^{-1} \mathrm{DW}$, respectively) (Figure $72 \mathrm{C}$ ). Perseitol concentration was only altered by the GA who managed to increase by $37 \%$, on average, compared to the rest of treatments (Figure $72 \mathrm{D}$ ). 
However, 10 days later (May 13), there was a widespread tendency to significantly increase the concentration of all sugars (except the sucrose), regardless of treatment. As a whole, and on average, glucose increased its content of $120 \%$, fructose $200 \%$, and sucrose and perseitol $57 \%$ and $150 \%$, respectively (Figure 72).

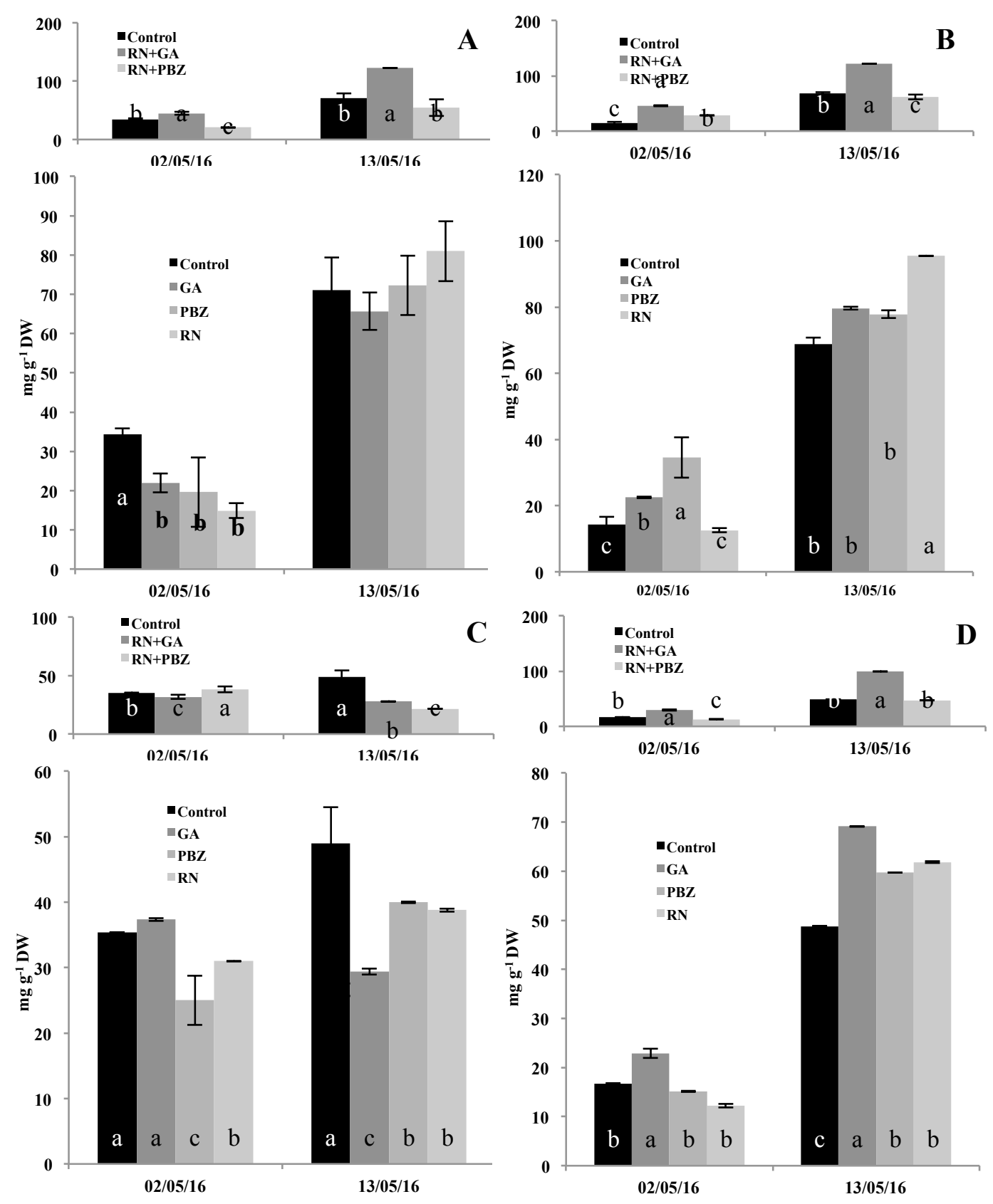

Figure 72: Influence of ringing and the application of GA $\left(50 \mathrm{mg} \mathrm{l}^{-1}\right)$ and PBZ $\left(50 \mathrm{mg} \mathrm{l}^{-1}\right)$ to the entire tree when $80 \%$ of the fruit had a diameter of $3 \mathrm{~mm}$ (phenological state $711 \mathrm{BBCH}$ scale), on the glucose content (A), fructose (B) sucrose (C) and in perseitol (D) in fruit sets cv. Hass avocado. Each value is the average of 4 samples. Date of treatments: 26/04/2016. The vertical bars indicate the standard error. GA: gibberellic acid; PBZ: Paclobutrazol; RN: Ringing. Different letters for a same date indicate significant differences $(P \leq 0.05)$. DW $=$ dry weight of the samples. 
As in previous cases the combination of the treatments showed erratic, improving the concentration of glucose, fructose and perseitol only in the case of the combination GA + ringing (Figure 72).

The analysis of variance revealed to the contents of glucose and fructose a statistically significant effect $(P \leq 0.01)$, both by the GA effect as by the ringing effect, and their interaction. This is undoubtedly due to the synergistic effect of the combination GA + ringing. Indeed, regardless of their individual action noted above, ringing of trees treated with GA increased glucose and fructose content of fruit in the two analysis dates (Figure $72 \mathrm{~A}$ and B). On the contrary, it failed in the sucrose content (Figure $72 \mathrm{C}$ ).

The effect of the treatments during the fruit set also changed the carbohydrate content of the leaves of the shoot of the panicle in growth. Thus, 7 days after treatment the leaves of ringing trees presented the greatest concentration of consumption sugars, glucose and fructose, with 16 and $14 \mathrm{mg} \mathrm{g}^{-1} \mathrm{DW}$, respectively, while the rest of the treatment, control, GA and PBZ, was for the glucose of 10, 7.5 and $5 \mathrm{mg} \mathrm{g}^{-1} \mathrm{DW}$, respectively, and $4.5 \mathrm{mg} \mathrm{g}^{-1} \mathrm{DW}$, on average, for the fructose (Figure $73 \mathrm{~A}$ and $\mathrm{B}$ ). Although the ringing effect was statistically significant, its combined effect with the treatments only increased the contents in the leaves of the trees treated in turn with GA, but its interaction did not reach statistical significance.

The concentration of sucrose was only modified by the AG and ringing, which reduced up to $25 \mathrm{mg} \mathrm{g}^{-1} \mathrm{DW}$ with respect to the control. A week later, the effect was lost reaching similar values (62 $\mathrm{mg} \mathrm{g}^{-1} \mathrm{DW}$ on average) for all treatments (Figure $73 \mathrm{C}$ ). The sucrose content of the leaves of the trees treated with PBZ did not differ from the control trees on any of the dates analysed (Figure $73 \mathrm{C}$ ). The statistical analysis of the results reveals statistical significance for the GA and ringing effects, as corresponds to the significantly lower values in these treatments in the first date of the analysis, and also for their interaction. Indeed, leaves treatment GA + ringing were the lowest concentration of sucrose presented at both dates of analysis, and it correlates well with the fact that on May 13 we had the treatment largest number of fruits kept on the tree (10 fruits per panicle) (Figure $54 \mathrm{~B}$ ). 
The perseitol content, on the contrary, increased in the leaves of the trees treated with GA in respect of the control trees on both dates of analysis, 6 and $8 \mathrm{mg} \mathrm{g}^{-1}$ DW, respectively (Figure $73 \mathrm{D}$ ). In the ringing trees we also observed a decrease in the concentration of perseitol on the first date of analysis $\left(5 \mathrm{mg} \mathrm{g}^{-1} \mathrm{DW}\right.$, with respect to the control) (Figure $73 \mathrm{D}$ ). The PBZ did not alter the perseitol content of leaves on control trees in any of the dates of the analysis. For this carbohydrate no significant interactions were detected between the treatments.

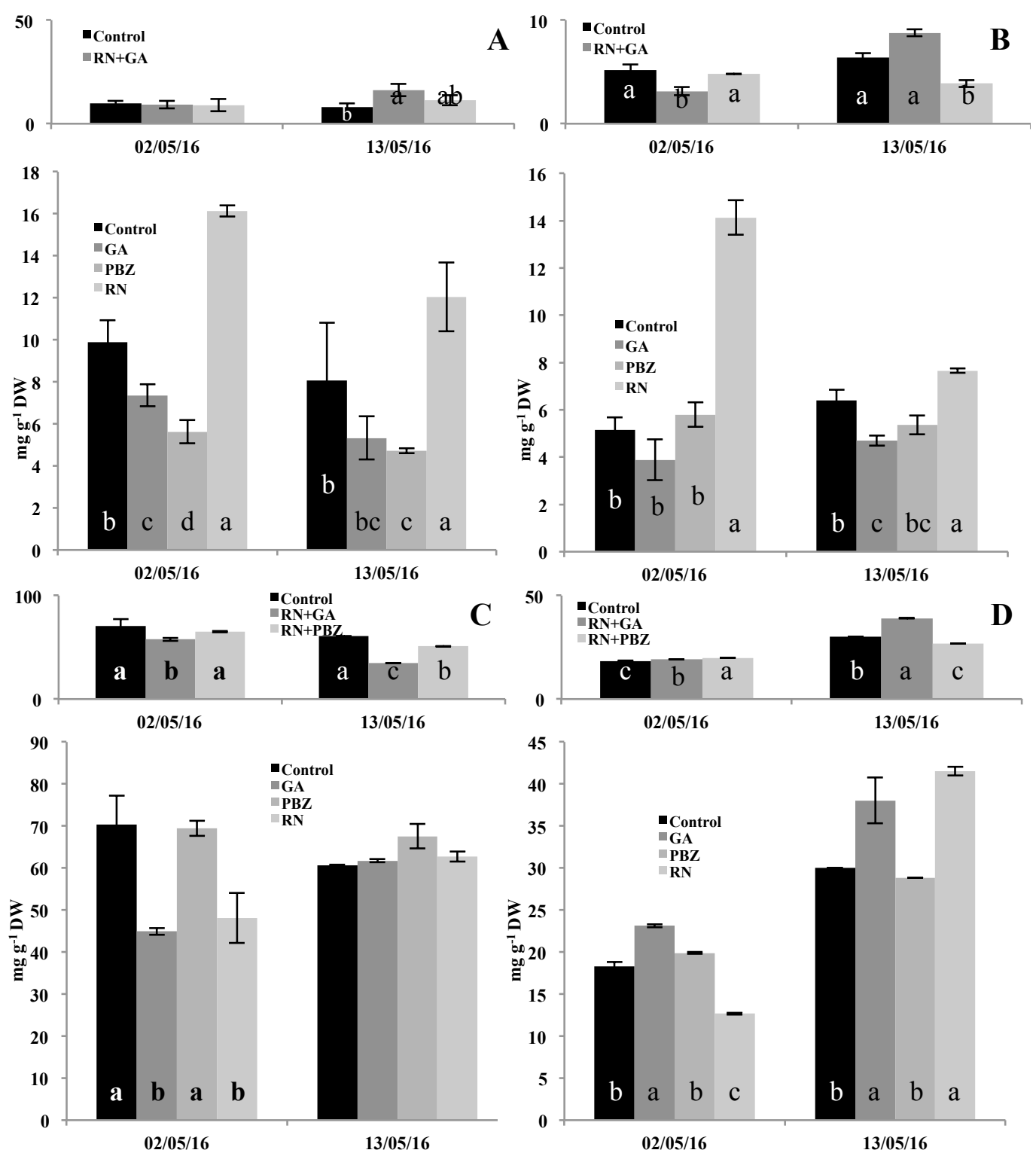

Figure 73: Influence of ringing and the application of GA $\left(50 \mathrm{mg} \mathrm{l}^{-1}\right)$ and PBZ (50 $\left.\mathrm{m} \mathrm{l}^{-1}\right)$ to the entire tree when $80 \%$ of the fruit had a diameter of $3 \mathrm{~mm}$ (phenological state 711 of the BBCH scale), on the glucose content (A), fructose (B) sucrose (C) and perseitol (D) in the shoots developed from the terminal bud of the panicle in cv. Hass avocado. Date of treatments 26/04/2016. Each value is the average of 4 samples. GA: gibberellic acid; PBZ: Paclobutrazol; RN: Ringing. The vertical bars indicate the standard error. Different letters for a same date indicate significant differences $(P \leq 0.05)$. DW $=$ dry weight of the samples. 


\subsection{Influence of $\mathrm{GA}_{3}$ and $\mathrm{PBZ}$ during anthesis and fruit set in the hormonal}

\section{balance}

The effect of the treatments also reached the hormonal balance of the fruit sets. Thus, the gibberellins $\left(\mathrm{GA}_{1}\right)$ content of the latter was only altered by the treatment with GA. Fifteen days after the application to panicles in anthesis, the concentration of $\mathrm{GA}_{1}$ on fruit set was significantly higher $\left(39 \mathrm{ng} \mathrm{g}^{-1} \mathrm{DW}\right)$ than the controls and treated with PBZ (17 $\left.\mathrm{ng} \mathrm{g}^{-1} \mathrm{DW}\right)$. What is more, a week later these differences were more significant because while in the first case the content increased dramatically up to $900 \mathrm{ng} \mathrm{g}^{-1} \mathrm{DW}$, in the second it did slightly, up to 45 $\mathrm{ng} \mathrm{g}^{-1} \mathrm{DW}$, and the third was reduced to practically null values.

It is worth noting this action of GA applied exogenously to promote the synthesis of gibberellins in the fruits set, although this does not succeed in reducing their abscission and therefore increase the number of fruits per panicle (see figure 54 A).

The response in the rest of the analysed hormones was different. To the 15 days of treatment, while the concentration of indolacetic acid (IAA) in the fruit sets of the panicles treated with PBZ was very low $\left(1 \mathrm{ng} \mathrm{g}^{-1} \mathrm{DW}\right)$, in the controls or treated with GA it was, on average, $67 \mathrm{ng} \mathrm{g}^{-1}$ DW (Table 5).

\begin{tabular}{|c|c|c|c|c|c|c|}
\hline \multirow{2}{*}{ Daa } & GA & PBZ & CNT & GA & PBZ & CNT \\
\hline & \multicolumn{5}{|c|}{ IAA (ng g $\left.{ }^{-1} \mathbf{D W}\right)$} & \multicolumn{3}{c|}{ tZ (ng g $\mathbf{~} \mathbf{~ D W})$} \\
\hline $\mathbf{1 5}$ & $66,9 \pm 0,1 \mathrm{~b}$ & $1,0 \pm 0,1 \mathrm{a}$ & $67,9 \pm \mathrm{b}$ & $50,2 \pm 0,07 \mathrm{c}$ & $2,9 \pm 0,7 \mathrm{~b}$ & $1,5 \pm 0,07 \mathrm{a}$ \\
\hline $\mathbf{2 0}$ & $76,5 \pm 2 \mathrm{a}$ & $63,6 \pm 6,9 \mathrm{a}$ & $119,2 \pm 3,1 \mathrm{~b}$ & $3,1 \pm 0,046 \mathrm{~b}$ & $1,6 \pm 0,1 \mathrm{a}$ & $32,7 \pm 4,18 \mathrm{c}$ \\
\hline $\mathbf{3 0}$ & $71,7 \pm 6,2 \mathrm{a}$ & $476,3 \pm 3 \mathrm{~b}$ & $93,5 \pm 23 \mathrm{a}$ & $9,3 \pm 0,3 \mathrm{a}$ & $317,8 \pm 47 \mathrm{~b}$ & $392,5 \pm 51 \mathrm{~b}$ \\
\hline
\end{tabular}

Table 5: Influence of the application of gibberellic acid (GA $50 \mathrm{mg} \mathrm{l}^{-1}$ ) and paclobutrazol (PBZ 50 $\mathrm{mg} \mathrm{l}^{-1}$ ) at anthesis (growth stage $610 \mathrm{BBCH}$ scale) to the entire tree on the content of indoleacetic acid (IAA) and trans-zeatin $(t Z)$ of the fruit. Each value is the mean of 4 samples. $\mathrm{GA}=$ giberellic acid; $\mathrm{PBZ}=$ Paclobutrazol; $\mathrm{CNT}=$ Control. Different letters in the same row indicate significant differences $(P \leq 0.05)$ for the same hormone.

Five days later all frits increased their IAA content, but while the control and treated with PBZ did in 51.3 and $62.7 \mathrm{ng} \mathrm{g}^{-1} \mathrm{DW}$, respectively, those of $\mathrm{GA}_{3}$ only did $9.5 \mathrm{ng} \mathrm{g}^{-1}$ DW (Table 5).

The application of $\mathrm{GA}_{3}$ also increased, significantly the content of the fruit in 
trans-zeatine $(t Z)$, reaching values of $50.2 \mathrm{mg} \mathrm{g}^{-1} \mathrm{DW}$, compared to 1.5 and 2.9 of the control fruits and treated with PBZ, respectively (Table 5). Five days later, and in contrast with the IAA, its concentration was reduced by $93 \%$ by the action of GA and $56 \%$ in the trees treated with PBZ, while increased 20 times in the control.

Finally, after 30 days of treatment the response was completely different: while those treated with GA maintained the concentration of IAA and slightly increased the $t \mathrm{Z}$, those treated with PBZ increased both concentrations dramatically, up to 7.5 times and 198 times more, respectively, and the controls decreased the IAA in $25.6 \mathrm{ng} \mathrm{g}^{-1} \mathrm{DW}$ and increased the $t \mathrm{Z}$ up to 12 times, thus achieving the maximum value (Table 5).

It is noteworthy that on this date the number of fruits per panicle in the trees treated with PBZ (1 fruit per panicle) and in the control (1.2 fruits per panicle) was significantly lower than in those treated with GA (6 fruits per panicle), which suggests, in the view of the initial hormonal values (15 days after treatment) an action governed by gibberellins and cytokinins on fruit set of this species. The delay of the abscission of fruits evidenced it, since it necessarily implies a greater number of initial fruit set.

When the application of GA was conducted 15 days later, the response in the content in gibberellin was the same. The fruit sets of control trees and the panicles treated with PBZ, a week after the treatment were, on average, $20 \mathrm{ng} \mathrm{g}^{-1}$ DW of $\mathrm{GA}_{1}$ while those treated with GA had $1500 \mathrm{ng} \mathrm{g}^{-1} \mathrm{DW}$. These differences are accentuated over time and 10 days later, while the concentration in the control remained almost stable, in those treated with PBZ and GA decreased and increased by $10 \%$ and $50 \%$, respectively.

The trend in the rest of the analysed hormones was identical, although with quantitative differences between them, and both the IAA and the $t \mathrm{Z}$ increased their content over time, regardless of the treatment. However, there were differences related to the treatments. Thus, a week after the application of GA and $\mathrm{PBZ}$, the concentration of IAA and $t Z$ in the fruit set was higher than that of the control, since in both cases the PBZ which registered higher values (59 $\mathrm{ng} \mathrm{g}^{-1} \mathrm{DW}$ and $83.9 \mathrm{ng} \mathrm{g}^{-1}$ DW more IAA than the $\mathrm{GA}_{3}$ and control, respectively) and (1.8 $\mathrm{ng}$ 
$\mathrm{g}^{-1}$ DW and $7 \mathrm{ng} \mathrm{g}^{-1}$ DW more than $\mathrm{tZ}$ ) (Table 6).

\begin{tabular}{|c|c|c|c|c|c|c|}
\hline \multirow{2}{*}{ Daa } & GA & PBZ & CNT & GA & PBZ & CNT \\
\hline & \multicolumn{5}{|c|}{ IAA (ng g ${ }^{-1}$ DW $)$} & \multicolumn{3}{c|}{ T (ng g $\mathbf{~}^{-1}$ DW $)$} \\
\hline $\mathbf{7}$ & $93,8 \pm 19,9 \mathrm{a}$ & $151,8 \pm 0,7 \mathrm{~b}$ & $67,9 \pm 0,2 \mathrm{a}$ & $6,7 \pm 0,86 \mathrm{~b}$ & $8,5 \pm 1,21 \mathrm{~b}$ & $1,5 \pm 0,07 \mathrm{a}$ \\
\hline $\mathbf{1 5}$ & $712,3 \pm 101,2 \mathrm{c}$ & $406,8 \pm 16,3 \mathrm{a}$ & $528,9 \pm 23,67 \mathrm{~b}$ & $259,7 \pm 35,3 \mathrm{~b}$ & $200,9 \pm 7,17 \mathrm{a}$ & $392,5 \pm 51,8 \mathrm{c}$ \\
\hline
\end{tabular}

Table 6: Influence of application of gibberellic acid (GA $50 \mathrm{mg}^{-1}$ ) and paclobutrazol (PBZ $50 \mathrm{mg}$ $\mathrm{l}^{-1}$ ) to the entire tree when $80 \%$ of the fruit had a diameter of $3 \mathrm{~mm}$ (phenological state $711 \mathrm{BBCH}$ Scale), on content of indolacetic acid (IAA) and trans-zeatine $(t Z)$ of the fruits. Each value is the mean of 4 samples. GA= giberellic acid; $\mathrm{PBZ}=$ Paclobutrazol; $\mathrm{CNT}=$ Control. Different letters in the same row indicate significant differences $(P \leq 0.05)$ for the same hormone.

Twelve days later, when almost all treatments had the same number of fruit sets (see Figure $54 \mathrm{~B}$ ), the concentration of IAA in those treated with GA was significantly higher, $712.3 \mathrm{ng} \mathrm{g}^{-1} \mathrm{DW}$, than the controls and treated with PBZ that was 528.9 and $406.8 \mathrm{ng} \mathrm{g}^{-1} \mathrm{DW}$, respectively (Table 6). The concentration of $t \mathrm{Z}$, however, was significantly higher in the controls (392.5 $\left.\mathrm{ng} \mathrm{g}^{-1} \mathrm{DW}\right)$ than in the treaties, for which it reached an average value of $230.3 \mathrm{ng} \mathrm{g}^{-1} \mathrm{DW}$.

Jointly analysing the hormone content of the fruit sets in the different treatments and time of realization of the same, quantitative notable significant differences are observed. For example, 15 days after the treatment the content of IAA in the fruit sets in the panicles treated with GA during anthesis was $66.9 \mathrm{ng} \mathrm{g}^{-1} \mathrm{DW}$, while in those treated during fruit set it was $712.3 \mathrm{ng} \mathrm{g}^{-1} \mathrm{DW}$. For $t \mathrm{Z}$ the differences were also remarkable and the concentration in the first case was of $50.2 \mathrm{ng} \mathrm{g}^{-1} \mathrm{DW}$ and in the second $259.7 \mathrm{ng} \mathrm{g}^{-1} \mathrm{DW}$ (Tables 5 and 6). Something similar happened with the treatment with the PBZ and control, it follows that the phenological state of the plant at the time of the treatment influences in a remarkable way in its effectiveness and in the hormonal response. 


\section{DISCUSSION}




\section{DISCUSSION}

In many fruit tree species, as for avocado and some citrus varieties, tree production is linked, among other factors, to flowering intensity. In some cases, as when a negative relationship between flowering intensity and fruit production is established, inhibition of flowering is requested to increase fruit production. In avocado, Chandler (1958) reported that fruit set is usually less than $0.02 \%$ of the total number of flowers produced.

Gibberellins are responsible for the sprouting in many fruit tree species (Faust, 1989) and are directly involved in the flowering process, interfering with it (Goldschmidt et al., 1997). Accordingly, the application of $\mathrm{GA}_{3}$ during the floral bud inductive period significantly reduces flowering intensity (Southwick and Glozer, 2000) of some fruit tree species such as citrus (El-Otmani et al., 2000), mango (Turnbull et al., 1996), pome fruit (McArtney and Li, 1998) and stone fruit (González-Rossia et al., 2006; 2007). In 'Hass' avocado, our results show a reduction of $50 \%$ of flowering by gibberellic acid when applied at a concentration of $50 \mathrm{mg} \mathrm{l}^{-1}$ during the floral bud inductive period (phenological stage 010 of the $\mathrm{BBCH}$ scale), coinciding with those obtained by Salazar-García and Lovatt (1997).

The inhibitory effect of gibberellic acid on flowering of fruit species also takes place through a reduction of bud sprouting, as reported for citrus (García-Luís et al., 1986) and loquat (Reig et al., 2011), reducing the number of inflorescences per tree (Reig et al., 2011). Our results agree with it, decreasing the number of sprouted nodes and, thus, reducing the number of developed panicles. Gibberellic acid (1000 ppm) also increased shoot growth of the indeterminate inflorescences (Salazar-García and Lovatt, 1999) and increased the number of vegetative apical shoots (Salazar-García and Lovatt, 1997).

In our experiments, especially in the orchard located at Caronia Marina, determinate panicles set more fruits than indeterminate ones. These results coincide with those reported by Wolstenholme and Whiley (1995), and Rosales et al. (2003), who claim for a strong competition among fruits, roots, and new shoots development. Cossio-Vargas et al., (2007) also reported a significant fruit drop in 
some periods in which vegetative growth and fruit development coincided, showing that competition between them directly affected crop load.

In this way, early and vigorous shoot elongation might have an adverse effect on fruit set. According to Schroeder (1944), in the cv. Fuerte, 5\% to $20 \%$ of the terminal buds may abort, the proportion increasing with increasing flowering. Therefore, in this case, no competition with vegetative growth takes place and a better fruit set and fruit size are reached (Whiley, 1994). Our results do not agree with this behaviour as the number of fruit sets at the end of the first physiological drop was identical regardless of the vigour of the shoot. Moreover, when PBZ was applied at two phenological stages, anthesis and fruit set, shoot vigour was significantly reduced, but fruit set was not, in contrast with Wolstenholm (1990) and Whiley et al. (2007), who increased fruit set and size by applying PBZ to reduce spring shoots growth.

Regarding the endogenous hormonal content, $\mathrm{GA}_{1}$ was not detected in our analysis. However, the decline in content of the precursor $\mathrm{GA}_{20}$ paralleled a significant increase, up to 3 -folds, of the $\mathrm{GA}_{29}$ content, which justifies the absence of $\mathrm{GA}_{1}$ in this process and suggests that the path of the 13-hidroxilation of the gibberellin synthesis in this species could be merely catabolic. The higher content of $t \mathrm{Z}$ in flowers during abscission, suggests that cytokinins might control the process.

It is interesting to note that IAA content precedes that of $t \mathrm{Z}$, suggesting that fruit set in avocado might be determined by an interaction between both hormones. In control trees an increase in IAA content precedes fruit set, and also the increase in $t Z$ content, suggesting an essential role regulating the process, i.e. the possibility that fertilization would trigger an auxin-mediated promotion of $t \mathrm{Z}$ synthesis. Similarly, interactions between auxins and gibberellins on early fruit set and development are well documented, especially in herbaceous plant species such as pea, tomato or arabidopsis (O'Neill and Ross, 2002; Ozga and Reinecke, 1999, 2003; Ollimpieri et al., 2007; Ozga et al., 2009; Serrani et al., 2008; Dorcey et al., 2009). In these species, evidence indicates that both hormones act coordinatedly inducing fruit set. 
Finazzo et al. (1994) studying the distribution and allocation of carbohydrates in avocado, showed that the availability of carbohydrates in the tree was sufficient to sustain the growth of developing fruitlets, leaves, and shoots during the early stages of fruit set, therefore the fruitlet abscission must not be due to the shortage of carbohydrates. It is in contrast with the results of Wolstenholme et al. (1990), who confirmed that foliar applications of PBZ at full bloom, significantly reduced shoot growth and increased crop load. However, for the avocado, it has been suggested that competition for carbohydrates among developing fruits (Sedgley, 1987), or between them and vegetative growth (Biran, 1979), is responsible for flowers/fruitlets. Nevertheless, Biran (1979), and Cutting and Bower (1990) reported that spring pruning increased fruit set, but did not affect the number of fruits harvested per tree, in agreement with our results. Furthermore, our results for determinate and indeterminate panicles show an intense competition between reproductive and vegetative organs at the early stages of flower development, but after fruit set this kind of competition disappears.

Therefore, the number of fruits per panicle at the end of the physiological fruitlet drop was the same, although the sugar content, reducing (glucose and fructose) and translocating (sucrose and perseitol) sugars, was not. And also, regardless of the treatment carried out and date of treatment. At the early stages of fruitlet development, i.e. the period of high energy demand, treatments improved fruit set and also increased carbohydrate content in the surviving fruitlet, suggesting a close relationship between the availability of carbohydrates and fruit set. However, this effect was lost over time and the differences in the carbohydrate content of fruits from different treatments was not related to the final number of developing fruits. Furthermore, in ringed branches, the delay of fruitlet abscission coincided with an increase in the sugar content, suggesting that nutritional aspects are not the primary responsible of the process. By contrast, trees treated with PBZ reduced the number of developing fruitlets and also the sugars (reducing and translocating) concentration. Since PBZ inhibits gibberellin synthesis, it suggests a hormonal control over the nutritional one.

The source-sink relationships play a key role in carbohydrates translocation in the tree. Sugars translocation is strongly influenced by developing sinks, so that the 
reproductive and vegetative organs compete for carbohydrates (Ho et al, 1989; Patrick, 1989), the fruit being a stronger sink and, therefore, carbohydrate translocation to the vegetative organs diminishes. Our results agree with it, as evidenced by the lower content of glucose and fructose in leaves of the apical shoot regarding those of the developing fruitlet. Up to 11 and 10-fold higher content of glucose and fructose, respectively, were detected in fruitlets than in the leaves of the longer shoots, which reflects the fruit sink strength. Not significant differences in sucrose and perseitol content were detected.

Interestingly, while in the abscissed flowers the most abundant translocating sugar was sucrose, in fruits newset it was perseitol. These results coincide with those of Liu et al (2002) and show that this 7C sugar is a translocating sugar in this species. The high concentration of glucose-6-P has been related to the energy required for the synthesis of lipids (Gandolfo, 2008).

Gibberellic acid applied at anthesis does not modified leaf concentration of glucose and fructose, but sucrose, that significantly increased.

In our experiments, gibberellic acid did not increased fruit set as, for example, it occurs in citrus (El-Otmani et al., 2000). However, trees treated with PBZ set significantly less fruits than the control and GA and ringed branches treated trees, suggesting that, nevertheless, it must be regulated hormonally. Besides, ringing branches did not compensate this PBZ depressive effect on fruit set, confirming that fruit set is not a merely nutritional controlled process. Furthermore, in citrus, ringing activates photosynthetic efficiency of photosystem II ( $\phi$ PSII) of young leaves 30 days after it was performed (Rivas et al., 2007), explaining the higher content in reducing carbohydrates in leaves and fruitlets in our experiment when ringing is performed at $3 \mathrm{~cm}$ fruit diameter. Since at this date of treatment ringing, and also GA, increased the number of developing fruitlets and their interaction became statistically significant, fruit development at this phenological stage is nutritionally dependent, as in other woody species (Faust, 1989). 
VI. CONCLUSIONS 


\section{CONCLUSIONS}

1. Gibberellic acid applied during the floral bud inductive period delayed sprouting, reduced the number of flowers per panicle, increased apical shoot length, and delayed fruitlet abscission.

2. Gibberellic acid applied at anthesis enhanced fruit set and delayed fruitlet abscission. It correlated with an immediate and temporary increase of GA, IAA and $t \mathrm{Z}$ content. But the $\mathrm{GA}_{1}$ immediately derived in its catabolite $\mathrm{GA}_{8}$.

3. Gibberellic acid applied at fruit set stage also enhanced fruit set, delayed fruitlet abscission, and temporarily increased $\mathrm{GA}_{1}$ and $\mathrm{GA}_{8}$ content, IAA and $t \mathrm{Z}$ showing an erratic behaviour.

4. Paclobutrazol applied at anthesis (610 BBCH scale) anticipated flower abscission, but did not affect initial fruit set.

5. Accordingly, in avocado, fruit set is regulated by cytokinins that ensure carbohydrate availability to the fruit for development. Since IAA synthesis precedes fruit set and $t \mathrm{Z}$ increasing content, the possibility that fertilization would trigger an auxin-mediated promotion of $t \mathrm{Z}$ synthesis cannot be discarded. 


\section{REFERENCES}




\section{REFERENCES}

- Alcaraz, M.L., Throp, T.G. Y Hormaza, J.I. 2013b. Phenological growth stages of avocado (Persea americana) according to the $\mathrm{BBCH}$ scale. Scientia Horticulturae 164, 434-439.

- Alcaraz, M., J. Rodrigo and J. Hormaza. 2011. Implications of starch content in the flower at anthesis on final fruit set in avocado. p 7. In: Proceedings VII World Avocado Congress. Cairns, Australia.

- Aubert, B. and Lossois, S. 1972. Considérations sur la phénologie des espèces arbustives. Fruits 27(4): 269-286.

- Bergh, B.O. 1969. Avocado (Persea americana Miller). In: Ferwerda, F.P. and Wit, F (eds). Outlines of Perennial Crop Breeding in the Tropics. Landbouwhogeschool, Wa- geningen, The Netherlands, pp. 23-51.

- Bergh, B.O. 1974. The remarkable avocado flower. Calif. Avo. Soc. Yrbk. $57: 40-41$.

- Bernal, J., and C. Díaz. 2005. Generalidades del cultivo. En: Tecnología para el cultivo del aguacate, Bernal, J., y Diaz, C. (Eds.). Manual Técnico 5, CORPOICA, Centro de Investigación. La Selva, Rionegro, Colombia. p. 11-84.

- Biran, D. 1979. Fruitlet abscission and spring growth retardation - their influence on avocado productivity. MSc thesis, The Hebrew University of Jerusalem, Rehovot, Israel.

- Blanke, M. and Whiley, A. 1995. Bioenergetics, respiration cost and water relations of developing avocado fruit. Journal of Plant Physiology 145, 87-92.

- Blanke, M. M.; Lovatt, C. J. 1998. Determinate versus indeterminate inflorescences of the 'Hass' avocado. Proc. World Avocado Congr. III. Tel Aviv, Israel. October 22-27, 1995. pp. 33- 36.

- Board, M., Colquhoun, A. and Newsholme, E.A. 1995. Hight $K_{m}$ glucosephosporylating (glucokinase) activities in a range of tumor cell lines and inhibition rates of tumor growth by the specific enzyme inhibitor mannoheptulose. Cancer Res. 55:3278-3285.

- Bower, J.P. and Cutting, J.G. 1988. Avocado fruit development and ripening physiology. Horticultural Reviews, 113: 229-71. 
- Bower, J.P., Lovatt, C.J., Cutting, J.G.M. and Blanke, M.M. 1990. Interaction of plant growth regulator and carbohydrate in flowering and fruit set. Acta Horticulturae 275: 425 - 434.

- Bruwer A, Robbertse P. 2003. Flowering of avocado (Persea americana Mill.) as in uenced by gibberellic acid treatments. En: Proc V World Avocado Congress. málaga, españa: Consejería de Agricultura y Pesca. pp. 227-230.

- Cabezas, C., J. Hueso y J. Cuevas. 2003. Identificación y descripción de los estados fenológicos y tipos de aguacate (Persea americana Mill) p. 237-242. En: Proceedings V World Avocado Congress. Granada - Málaga, España.

- Calabrese, F. 1992. El aguacate. Madrid. Ediciones Mundi-Prensa. 249 p.

- Can-Alonzo C, Quezada-euán j, Xiu-Ancona P, moo-Valle H, Valdovinosnúñez G, medina-Peralta s. 2005. Pollination of 'criollo' avocados (Persea americana) and the behaviour of associated bees in subtropical mexico. $\mathrm{j}$ Apicult Res 44(1):3-8.

- Cerdas, M., M. Calderón and E. Díaz. 2006. Manual de Manejo Pre y Poscosecha de Aguacate (Persea americana). MAG. San José, Costa Rica. 95 p.

- Chacko, E. K., Singh, R. N., and Kachru, R. B. 1972. Studies on the Physiology of Flowering and Fruit Growth in Mango (Mangifera Indica L). Vii. Naturally Occurring Auxins and Inhibitors in the Shoots of Flowering (On) 1 and Vegetative (Off) 2 Mango Trees. Indian Journal of Horticulture, 29(2), 115-125.

- Chandler, W.H. 1985. Evergreen Orchards, 2nd end. Lea and Febiger, Philadelphia, Pennsylvania, pp. 205-228.

- Cossio-Vargas, L., S. Salazar-García, I. González-Duran and R. MedinaTorres. 2007. Algunos aspectos reproductivos del aguacate 'Hass' en clima semicálido. p. 11. En: Proceedings VI World Avocado Congress. Viña Del Mar, Chile.

- Cristoffanini, L. 1996. Caracterización de la floración en paltos (Persea americana Mill.) cvs. Fuerte, Gwen, Whitsell and Esther. Universidad Católica de Valparaíso. Facultad de Agronomía. Área Fruticultura. Quillota, Chile. 67 p.

- Cutting, J.G.M. And Bower, J.P. 1990. Spring vegetative flush removal: the effect on yield, size, fruit mineral composition and quality. South African Avocado Growers Association Yearbook 13, 33-34. 
- Davenport T.L. 1982. Avocado growth and development. Proc. Fla. State Hort. Soc. 95: 92-96.

- Davenport, T.L. 1986. Avocado flowering. Horticultural Reviews 8, 257-289.

- Dixon J. and D. Sher. 2002. Pollination of avocados. Annual Research Report of New Zealand Avocado Growers Association 2: 31-40.

- Dixon, J. 2007. Shoot growth of 'Hass' avocado trees in 'on' and 'off' flowering years in the western bay of Plenty. Annual Research Report of New Zealand Avocado Growers Association 7: 41-48.

- Dorcey, E., Urbez, C., Blázquez, M. A., Carbonell, J., and Perez-Amador, M. A. 2009. Fertilization-dependent auxin response in ovules triggers fruit development through the modulation of gibberellin metabolism in Arabidopsis. The Plant Journal, 58(2), 318-332.

- Eaks, I. 1990. Change in the fatty acid composition of avocado fruit during ontogeny, cold storage and ripening. Tropical Fruit in International Trade. Acta Horticulturae 269: 141-151.

- El-Otmani, M., Coggins, C., Agustí, M. Y Lovatt, C.J. 2000. Plant Growth Regulators in Citriculture: World current Uses. Crit. Rev. Plant Science. 19:5, $395-447$.

- F. Rivas, Gravina, A. and Agustí, M. 2007. Girdling effects on fruit set and quantum yield efficiency PSII in two Citrus cultivars. Tree Physiology, 27: 527535.

- Faust, M. 1989. Physiology of temperature zone fruit trees, Ed. John Wiley \& Sons, 1989 pp. x + 338 pp. NY, EEUU.

- Finazzo, S.F., Davenport, T.L. And Schaffer, B. 1994. Partitioning of photoassimilates in avocado (Persea americana Mill.) during flowering and fruit set. Tree Physiology 14, 153-164.

- Gandolfo, S.P., 2008. Factores Ecofisiológicos Relacionados con el Crecimiento Vegetativo, Floración y Desarrollo del Fruto del Aguacate. Tesis doctoral. Universidad Politécnica de Valencia. Departamento de Producción Vegetal. $211 \mathrm{p}$.

- Garcia-Luis, A., Almela, V., Monerri, C., Agustí, M., and Guardiola, J. L. 
1986. Inhibition of flowering in vivo by existing fruits and applied growth regulators in Citrus unshiu. Physiologia plantarum, 66(3), 515-520.

- Gardiazabal, F. 2004. Riego y nutrición en paltos. En: Segundo Seminario Internacional de Paltos. Sociedad Gardiazabal y Magdahl Ltda. Quillota, Chile. 21 p.

- Garner, L.C. and C.J. Lovatt. 2008. The relationship between flower and fruit abscission and alternate bearing of 'Hass' avocado. J. Amer. Soc. Hort. Sci. 133:3-10.

- Gazit, S. and Degani, C. 2002. Reproductive biology. In: A.W. Whiley, B. Schaffer and B.N. Wiolstenholme, Editors, The Avocado, CABI Publishing, Oxon (2002), pp. 101-133.

- Goldschmiidt, E., Tamim, M. and Goren, R. 1997. Gibberellins and flowering in citrus and other fruit trees: A critical analysis. Acta Hortic. 463, 201208.

- González-Rossia, D., Juan, M., Reig, C. and Agustí, M. 2006. The inhibition of flowering by means of gibberellic acid application reduces the cost of hand thinning in Japanese plums (Prunus salicina Lindl.). Scientia Horticulturae. 110, 319-323.

- González-Rossia, D., Reig, C., Juan, M. and Agustí, M. 2007. Horticultural factors regulating effectiveness of $\mathrm{GA}_{3}$ inhibiting flowering in peaches and nectarines (Prunus persica L. Batsch) Scientia Horticulturae. 111, 352-357.

- Guardiola, J. L., Acusri, M., and Garcia-Mar, F. 1977. Gibberellic Acid And Flower Bud Development In Sweet. In Proc. Int. Soc. Citriculture (Vol. 2).

- Guardiola, J. L., García-Marí, F., and Agustí, M. 1984. Competition and fruit set in the Washington navel orange. Physiologia plantarum, 62(3), 297-302.

- Gustafson, C.O., and B.O. Bergh. 1976. History and review of studies on cross pollination of avocados. Calif. Avocado Soc. Yearb. 50:39-49.

- Hernández, F. 1991. Aproximación al ciclo fenológico del palto (Persea americana Mill.) cv. "Hass". p. 103. Tesis Ingeniero Agrónomo. Universidad Católica de Valparaíso, Facultad de Agronomía, Quillota, Chile.

- Ho, L.C, Gange, R.I and Shaw, A.F. 1989. Source/sink regulations. In: Transport of photoassimilates, Baker, D.A; Milburn, J.A. (Eds.), Longman 
Scientific and Technical, Harlow, UK, pp.306-344.

- Iwahori, S.; Oohata, J.T. 1981. Control of flowering of Satsuma mandarins (Citrus unshiu Marc) with gibberellin. Proc. Int. Soc. Citricult. 1: 247-249.

- Jackson, D.I. and Sweet, G.B. 1972. Flower initiation in temperate woody plants. Hortic. Abstr. 42:9-24.

- Kalmar, D. and Lahav, E., 1976. Water requirement of the avocado tree in the Western Galilee (1968-1974). Div. Sc. Publ. Bet Dagan. Pamphlet No. 157.

- Kohne, J. 2004. Flowering, fruit development and manipulation of yield in avocado. p. 9. En: Memorias Segundo Seminario Internacional de Paltos. Quillota, Chile.

- Köhne, J.S. and Kremer-Kóhne, S. 1987. Vegetative growth and fruit retention in avocado as affected by a new plant growth regulator (paclobutrazol). South African Avocado Growers1 Assn. Yrbk. 10, 64-66.

- Lahav, E., Zamet, D., 1999. Flowers, fruitlets and fruit drop in avocado trees. In: Proc. IV World Avocado Congress, Mexico, pp. 95-100.

- Laskowski, L. 2006. Características de la abscisión del fruto de naranja Citrus sinensis (L.) Osbeck var. Salustiana. Bioagro 18(1): 25-30.

- Leon, P. and Sheen, J. 2003. Sugar and hormone connections. Trends Plant Sci 8 (3):110-6.

- Lesley, J.W. and Bringhurst, R.S. 1951. Environmental conditions affecting pollination of avocados. California Avocado Society Yearbook 1951, 169-173. Reproductive Biology 129.

- Liu, X., Robinson, P., Madore, M., Witney, G. and Arpaia, M. 1999a. Hass avocado carbohydrate fluctuations. I. Growth and phenology. Journal of the American Society for Horticultural Science 124: 671-675.

- Liu, X., Robinson, P., Madore, M., Witney, G. and Arpaia, M. 1999b. Hass avocado carbohydrate fluctuations. II. Fruit growth and ripening. Journal of the American Society for Horticultural Science 124: 676-681.

- Liu, X., Sievert, J., Arpaia, M. and Madore, M. 2002. Postulated physiological roles of the seven-carbon sugars, mannoheptulosa and perseitol in avocado. Journal of the American Society for Horticultural Science 127: 108-114.

- Lomas j, Zamet Dn. 1994. Long term analysis and modelling of agroclimatic e 
ects on national avocado yields in Israel. Agr Forest meteorol 71:315-336

- Lovatt, C. 1990. Factors affecting fruit set/early fruit drop in avocado. California Avocado Society Yearbook 74: 193-199.

- Lovatt, C. 2006. Eliminating Alternate Bearing of the 'Hass' Avocado. pp. 127-142. In: Proceedings of the California Avocado Research Symposium. University of California, Riverside, USA.

- Luza, J.G.; Lizana, L.A. and Masson, L., 1990. Comparative lipids evolution during cold storage of three avocado cultivars. Acta Horticulturae 269, Tropical Fruit in International Trade.

- Mcartney, S. J., and Li, S. H. 1998. Selective Inhibition of Flowering onBraeburn'Apple Trees with Gibberellins. HortScience, 33(4), 699-700.

- Monselise, S. P., Havely, A. H 1964. Chemical inhibition and promotion of citrus flower bud induction. Proceedings of the American Society of the Horticultural Science, Alexandria, v.84, p.141-6.

- Muñoz-Fambuena, N., C. Mesejo, M.C. González-Mas, E. Primo-Millo, M. Agustí and D.J. Iglesias. 2011. Fruit regulates seasonal expression of flowering genes in alternate-bearing 'Monacad' mandarin. Annals of Botany, 108: 511-519.

- Muñoz-Fambuena, N., Mesejo, C., González-Mas, M. C., Iglesias, D. J., Primo-Millo, E., and Agustí, M. 2012a. Gibberellic acid reduces flowering intensity in sweet orange [Citrus sinensis (L.) Osbeck] by repressing CiFT gene expression. Journal of Plant Growth Regulation, 31(4), 529-536.

- Muñoz-Fambuena, N., Mesejo, C., González-Mas, M.C., Primo-Millo, E., Agustí, M. and Iglesias, D.J. 2012b. Fruit load modulates flowering-related gene expression in buds of alternate bearing 'Moncada' mandarin. Annals of Botany, 110: 1109-1118.

- Naylor, A.W., 1984. Functions of hormones at the organ level of organization. In: Hormonal regulation of development II. Encyclopedia of plant physiology. New series. vol. 10:172-218.

- Nir, I., Goren, R., \& Leshem, B. 1972. Effects of water stress, gibberellic acid and 2-chloroethyltrimethylammoniumchloride (CCC) on flower differentiation in'Eureka'lemon trees. J. Amer. Soc. Hort. Sci, 97, 774-8.

- Núeñz-Elisea, R. and Davenport, T.L. 1991. Effect of low temperature 
treatment on flowering of containerized 'Tommy Atkins' mango. HortScience 26, 751.

- O'Neill, D. P., \& Ross, J. J. 2002. Auxin regulation of the gibberellin pathway in pea. Plant Physiology, 130(4), 1974-1982.

- Olimpieri, I., Siligato, F., Caccia, R., Soressi, G. P., Mazzucato, A., Mariotti, L., and Ceccarelli, N. 2007. Tomato fruit set driven by pollination or by the parthenocarpic fruit allele are mediated by transcriptionally regulated gibberellin biosynthesis. Planta, 226(4), 877-888.

- Oliveira, C.M. and Priestley, C.A.. 1988. Carbohydrate reserves in deciduous fruit trees. Hort. Rev. 10:403-430.

- Ozga, J. A., and Reinecke, D. M. 1999. Interaction of 4-chloroindole-3-acetic acid and gibberellins in early pea fruit development. Plant growth regulation, 27(1), 33-38.

- Ozga, J. A., and Reinecke, D. M. 2003. Hormonal interactions in fruit development. Journal of Plant Growth Regulation, 22(1), 73-81.

- Ozga, J. A., Reinecke, D. M., Ayele, B. T., Ngo, P., Nadeau, C., and Wickramarathna, A. D. 2009. Developmental and hormonal regulation of gibberellin biosynthesis and catabolism in pea fruit. Plant physiology, 150(1), 448-462.

- Patrick, J.W. 1989. Asimílate partitioning in relation to crop productivity HortScience. 23: 33-40.

- Paz-Vega, S. 1997. Alternate bearing in the avocado (Persea americana Mill.). California Avocado Society Yearbook 81: 117-148.

- Reig, C., Farina, V., Volpe, G., Mesejo, C., Martinez-Fuentes, A., Barone, F., Calabrese, F. and Agustí, M. 2011. Gibberellic acid and flower bud development in loquat (Eriobotrya japonica Lindl.). Scientia Horticulturae 129, $27-31$.

- Richtmyer, N.K. 1970. The isolation of volemitol and other polyhydric alcohols from avocado seeds. Carbohydrate Research 12: 135-138.

- Rivas, F., Gravina, A. and Agustí, M. 2007. Girdling effects on fruit set and quantum yield efficiency of PSII in two Citrus cultivars. Tree Physiol. 27, 527535. 
- Rocha-Arroyo, J., S. Salazar-García, A. Bárcenas-Ortega, J. GonzálezDurán y R. Medina-Torres. 2011. Crecimientos vegetativo y reproductivo del aguacate 'Hass' en diversos climas de Michoacán, México. p 10. En: Memorias VII World Avocado.

- Rosales, J., G. Parodi and B. Carlini. 2003. Evaluación del ciclo fenológico del palto (Persea americana Mill) cv. Hass para la zona de la irrigación Santa Rosa, Perú. p. 311-316. En: Proceedings V World Avocado Congress. Granada Málaga, España.

- Salazar-García, S., E.M. Lord and C.J. Lovatt. 1998. Inflorescence and flower development of the 'Hass' avocado (Persea americana Mill.) during "on" and "off” crop years. J. Amer. Soc. Hort. Sci. 123: 537-544.

- Salazar-García, S., L. Cossio-Vargas, C. Lovatt, I. González-Duran and M. Pérez- Barraza. 2006. Crop load affects vegetative growth flushes and shoot age influences irreversible commitment to flowering of Hass avocado. HortScience 41(7): 1541- 1546 .

- Salazar-García, S., L. Cossio-Vargas, I. González-Durán y C. Lovatt. 2007. Desarrollo floral del aguacate 'Hass' en clima semicálido. Parte I. Influencia de la carga de fruto y edad de los brotes. Revista Chapingo Serie Horticultura. 13(1): 87-92.

- Salazar-García, S., Lord, E.M. and Lovatt, C.J. 1999. Inflorescence development of the 'Hass' avocado: commitment to flowering. J. Amer. Soc.Hort. Sci. $124: 478-482$.

- Salazar-García, S.; Lovatt, C. J. 2000. Use of $\mathrm{GA}_{3}$ to manipulate flowering and yield of 'Hass' avocado. J. Amer. Soc. Hort. Sci. 125: 25-30.

- Scholefield, P.B., Sedgley M. and Alexander, D.McE., 1985. Carbohydrate cycling in relation to shoot growth, floral initiation and development and yield in theavocado. Scientia Horticulturae 25, 99-110.

- Schroeder, C.A. 1994. The avocado inflorescence. California Avocado Society Yearbook 1944, 39-40.

- Scora R, Wolstenholme B, Lavi u. 2007. El palto, botánica, producción y usos Taxonomía y botánica. pp. 25-45. En: Whiley A, Scha er B, Wolstenholme B, editores. Valparaíso, Chile: CABI; ediciones universitarias de Valparaíso. 
- Scora, R., B. Wolstenholme and U. Lavi. 2002. Chapter 2. Taxonomy and Botany. p. 25- 45. En: Whiley, A., B. Schaffer y B. Wolstenholme (ed.). The avocado, botany, production and uses. First Edition. CABI Publishing. Londres, U.K.

- Sedgley, M. 1987. Flowering, pollination and fruit-set of avocado. S. Afr. Avocado Growers' Assoc. Yrbk. 10:42-43.

- Sedgley, M. and Alexander, D.M. 1983. Avocado breeding research in Australia. Calif. Avocado Soc. Yrbk. 67:129-135.

- Sedgley, M. and C.M. Annells. 1981. Flowering and fruit-set response to temperatures during flowering on oral cycle and pollen tube growth in nine avocado cultivars. Sci. Hort. 18:207-213.

- Seo, Mitsunori, and Tomokazu Koshiba 2011. "Transport of ABA from the site of biosynthesis to the site of action." Journal of plant research 124.4: 501-507.

- Serrani, J. C., Ruiz-Rivero, O., Fos, M., \& García-Martínez, J. L. 2008. Auxin-induced fruit-set in tomato is mediated in part by gibberellins. The Plant Journal, 56(6), 922-934.

- Southwick, S.M. and Glozer, K. 2000. Reducing flowering with gibberellin to increase fruit size in stone fruit trees: applications and implications in fruit production. HortTchnology. 10, 744-751.

- Stout, A.B. 1923. A study in cross-pollination of avocado in southern California. Calif. Avoc. Association Ann. Report 8:29-45.

- Tesfayac, S.Z., Berling, I., Bower J.P And Lovatt,C. 2012. The quest for the function of Hass avocado carbohydrates: cleus from fruit and seed development as well as seed germination. Australian Journal of Botany, 60, 79-86.

- Thorp, T. G., Aspinall, D. and Sedgley, M. 1993. Influence of shoot age on floral development and early fruit set in avocado (Persea americana Mill.) cv. 'Hass'. J.Hort. Sci. 68:645-651.

- Turnbull, C.G., Anderson, K.L. and Winston, E.C. 1996. Influence of gibberellin treatment on flowering and fruiting patterns in mango. Austr. J. Exp. Agric. 36, 603-611.

- Velásquez, J. 2006. Identificación del aguacate como un rubro importante de 
grandes oportunidades comerciales, según los acuerdos de integración, los nuevos tratados comerciales y el comercio mundial globalizado. Secretaría de Productividad y Competitividad. Gobernación de Antioquia. Medellín, Colombia.103 p.

- Whiley A.W., Schaffer, B. and Lara, S.P. 1992. Carbon dioxide exchange of developing avocado (Persea americana Mill.) fruit. Tree Physiology 11, 85-94.

- Whiley, A., K. Chapman and J. Saranah. 1988. Water loss by floral structures of avocado (Persea americana cv. Fuerte) during flowering. Aust. J. Agric. Res. 39(3): 457-467.

-Whiley, A.W. and Schaffer, B. 1994. Avocado. In: Schaffer, B. and Anderson, P.C (eds) Handbook of Environmental Physiology of Fruit Crops, Vol. II, SubTropical and Tropical Crops. CRC Press, Boca Rton, Florida, pp. 3-35.

- Whiley, A.W., Schaffer, B. Y Wolstenholme, B.N. 2007. El Palto. Botánica, producción y usos. Ediciones Universitarias de Valparaíso. Chile.

-Wolstenholme, B., A. Whiley and J. Saranah. 1990. Manipulating vegetative: reproductive growth in avocado (Persea americana Mill.) with Paclobutrazol foliar sprays. Scientia HorticuIturae 41: 315-327.

- Wolstenholme, B.andy A. Whiley. 1995. Strategies for maximising avocado productivity: An overview. p 61-70. In: Proceedings III World Avocado Congress. Tel Aviv, Israel.

-Wolstenholme, B.N. 1990. Resource allocation and vegetative reproductive competition: opportunities for manipulation in evergreen fruit trees. Acta Horticulturae 275, 451-459.

- Wright, C.J., 1989. Interactions between vegetative and reproductive growth. In: Manipulation of fruiting ed.: Wright, C.J., Butterworths, London, Boston, Singapore, Toronto, Wellington, 15-27.

- Zamet. 1999. Flower, fruitlets and fruit drop in avocado trees. Revista Chapingo Serie Hort. 5:95-100.

- Ziv, D., Zviran, T., Zezak, O., Samach, A., \& Irihimovitch, V. 2014. Expression Profiling of FLOWERING LOCUS T-Like Gene in Alternate Bearing 'Hass' Avocado Trees Suggests a Role for PaFT in Avocado Flower Induction. PloS one, 9(10), e110613. 